\author{
Krzysztof KWIATKOWSKI \\ https://orcid.org/0000-0003-1827-3122 \\ Uniwersytet Mikołaja Kopernika w Toruniu
}

\title{
Oryginalne fragmenty kroniki Wiganda von Marburg - opis źródłoznawczy, nowa edycja i polskie tłumaczenie*
}

Zarys treści: Artykuł zawiera nową edycję oryginalnych fragmentów kroniki Wiganda von Marburg, które zachowały się do czasów współczesnych. We wstępie do edycji omówiona została jej podstawa rękopiśmienna z uwzględnieniem dotychczasowych wydań, a także przedstawione zostały zasady edytorskie. Edycja obejmuje łącznie 11 fragmentów oryginalnego rymowanego tekstu kroniki napisanej w latach 1393-1394 w języku średnio-górno-niemieckim. Fragmenty te zachowały się jako resztki dwóch późnośredniowiecznych rękopisów oraz w XVI-wiecznym wydaniu kroniki Caspara Schütza. Do oryginalnego tekstu dołączone zostały odpowiednie fragmenty łacińskiego tłumaczenia kroniki na podstawie nowej edycji z $2017 \mathrm{r}$.

\begin{abstract}
The article presents a new edition of the original fragments of Wigand von Marburg's chronicle that have been preserved. In the introduction, the author discusses its manuscript basis, taking into account its previous editions and the editorial principles. The edition includes a total of eleven fragments of the original text of the chronicle in verse, written in 1393-1394 in Middle High German. These fragments have survived as remains of two late-medieval manuscripts and in the sixteenth-century edition of Caspar Schütz's chronicle. The original text is supplemented by the relevant extracts of the Latin translation of the chronicle, based on its new edition published in 2017.
\end{abstract}

Slowa kluczowe: średniowiecze, piśmiennictwo, kroniki, tłumaczenia, zakon niemiecki, Prusy, Wigand von Marburg Keywords: Middle Ages, writings, chronicles, translations, Teutonic Order, Prussia, Wigand von Marburg

Zakończone w 2017 r. prace nad nową edycją i polskim tłumaczeniem łacińskiego przekładu kroniki Wiganda von Marburg ${ }^{1}$ stworzyły okazję do ponownego zajęcia się zachowanymi do dziś fragmentami

* W niniejszym artykule zastosowano następujące skróty: SRP - Scriptores rerum Prussicarum; Wigand (H) - Die Chronik Wigands von Marburg. Originalfragmente, lateinische Uebersetzung und sonstige Ueberreste, wyd. Th. Hirsch, w: SRP, t. 2, Leipzig 1863, s. 453-662; Wigand (H:ZF) - Zwei Fragmente der Reimchronik Wigands von Marburg, wyd. Th. Hirsch, w: SRP, t. 4, Leipzig 1870, s. 1-8; Wigand (H/A) - Ein Fragment der Reimchronik Wigands von Marburg, wyd. W. Hubatsch, U. Arnold, w: SRP, t. 6, Frankfurt am Main 1968, s. 44-49; Wigand (J/T/G) - Vygandas Marburgietis, Naujoji Prūsijos kronika, tłum. R. Jasas, red. K. Gudmantas, Vilnius 1999; Wigand (Z/K) - Wigand von Marburg, Cronica nova prutenica, oprac. S. Zonenberg, K. Kwiatkowski, Toruń 2017. W przypisach do edycji tekstu źródłowego posłużono się dodatkowo syglami: $\mathrm{H}=$ Theodor Hirsch; Th = Herbert Thoma; H i A = Walther Hubatsch i Udo Arnold; B = rękopis B.

${ }^{1}$ Wigand (Z/K). O autorze kroniki zob. S. Zonenberg, Kronika Wiganda z Marburga, Bydgoszcz 1994, s. 53-89; tenże, Wstęp źródłoznawczy i historyczny, w: Wigand (Z/K), s. 23-34; R. Trimoniené, Vygando Marburgiečio kronika. Ivadas, w: Wigand (J/T/G), s. 5-45; Th. Hirsch, Einleitung, w: Wigand (H), s. 448-451. Autorem łacińskiego thumaczenia rymowanej kroniki napisanej w języku średnio-górno-niemieckim był toruński duchowny Konrad Gesselen; zob. o nim m.in. 
oryginalnego dzieła napisanego w Prusach w końcu XIV w., a już w XVII stuleciu uznawanego za zaginione $^{2}$. Ponieważ analiza źródłoznawcza ułomków oryginalnych rymów Wiganda nie została objęta wspomnianym projektem edytorsko-translatorskim ${ }^{3}$, chciałbym ją przeprowadzić w niniejszym artykule. Zawiera on również nową krytyczną edycję wszystkich znanych dziś fragmentów pierwotnego dzieła Marburczyka wraz z paralelnym polskim tłumaczeniem, stanowiąc tym samym dopełnienie przywołanej wyżej publikacji sprzed czterech lat.

Historia odnajdywania kolejnych fragmentów oryginalnej kroniki Wiganda von Marburg została już przedstawiona w kilku XIX- i XX-wiecznych publikacjach ${ }^{4}$, dlatego nie ma potrzeby prezentować jej na nowo, tym bardziej że od 1937 r. nie odnaleziono już żadnych nowych ułomków zaginionego dzieła. Traktując rzecz z perspektywy tekstologicznej, znanych jest łącznie 11 fragmentów kroniki (w niniejszej edycji numerowane są one w kolejności narracyjnej kroniki przy użyciu cyfr rzymskich I-XI) ${ }^{5}$, przy czym treść dwóch z nich (VII i VIII) zachowała się częściowo w dwóch odrębnych fizycznie przekazach źródłowych, stąd w literaturze przedmiotu pisze się niekiedy o 12 fragmentach ${ }^{6}$. Owych 11 niezbyt długich fragmentów (zawierających od 6 do 140 wersów każdy) obejmuje łącznie 573 pełne wersy i 57 wersów zachowanych fragmentarycznie 7 . Pięć fragmentów dostępnych jest współcześnie jedynie we wczesnonowożytnej drukowanej edycji kroniki Caspara Schütza Historia rerum Prussicarum, wydanej po raz pierwszy w 1592 r., a następnie pod tym samym tytułem w 1599 r. (w kolejności: II, III, IX, X i XI) ${ }^{8}$. Pozostałe sześć urywków (I, IV, V, VI, VII i VIII) zachowało się w resztkach rękopisów późnośredniowiecznych, obecnie przechowywanych w Wiedniu, Monachium i Karlsruhe9. Porównanie zewnętrznych cech pisma występującego w owych sześciu fragmentach wskazuje, że pochodzą one z dwóch niezachowanych kodeksów zawierających pierwotnie kopie (odpisy) zapewne całej kroniki Wiganda von Marburg. Rozróżnienie to jest tym bardziej jednoznaczne, że wspomniane

M. Perlbach, Der Übersetzer des Wigands von Marburg, „Altpreußische Monatsschrift”, 32, 1895, s. 411-424; A. Blaschka, Monumentum Thorunense, „Wissenschaftliche Zeitschrift der Martin Luther Universität Halle-Wittenberg”, 7, 1957/1958, nr 4, s. 715-726; tenże, Konrad Gesselen, ein Mitarbeiter von Johannes Dlugosz. Epilog zum „,Monumentum Thorunense”, „Wissenschaftliche Zeitschrift der Martin Luther Universität Halle-Wittenberg”, 10, 1961, nr 4, s. 893-895; M. Sumowski, Duchowni diecezjalni w średniowiecznym Toruniu. Studium prozopograficzne, Torun 2012, s. 194-196; S. Zonenberg, Kronika, s. 19-26; tenże, Wstęp, s. 29-30.

${ }^{2}$ Zob. Ch. Hartknoch, Alt- und Neues Preussen oder Preussischer Historien, Franckfurt-Leipzig 1684, Vorrede, s. [10]; Th. Hirsch, Einleitung, s. 430; S. Zonenberg, Kronika, s. 19; J. Wenta, Studien über die Ordensgeschichtsschreibung am Beispiel Preußens, Subsidia Historiographica, t. 2, Torun 2000, s. 228.

${ }^{3}$ W edycji z 2017 r. jedynie wskazano (przy zastosowaniu not marginesowych oraz odpowiednich markerów początkowych i końcowych w tekście) passusy łacińskiego tekstu, dla których zachowały się oryginalne rymowane fragmenty; zob. Wigand (Z/K), s. 152-156, 184, 190, 204, 204-206, 214-216, 234-236, 244, 254-260, 290, 296-298, 480 (w podanych zakresach tekst łaciński edycji źródłowej tylko na stronach parzystych).

${ }^{4}$ Wigand (H), s. 441-442; H. Thoma, Ein neues Bruchstück aus der Reimchronik Wigands von Marburg, „Zeitschrift für deutsches Altertum und deutsche Literatur", 74, 1937 s. 39-41; Wigand (H/A), s. 44.

${ }^{5}$ Numeracja ta została wprowadzona do przywołanej edycji z 2017 r., zob. przyp. 3.

${ }^{6}$ Zob. G. Vollmann-Profe, Wigand von Marburg, w: Die deutsche Literatur des Mittelalters. Verfasserlexikon, t. 11: Nachträge und Korrekturen, red. B. Wachinger, G. Keil, K. Ruh, W. Schröder, F.J. Worstbrock, wyd. 2, Berlin-New York, 2004, szp. 1659. Błędnie pisze się także o 10 fragmentach, zob. tamże; M. Malm, Wigand von Marburg, w: Deutsches Literatur-Lexikon. Biographisches-bibliographisches Handbuch, t. 32, wyd. 3, Berlin-Boston, 2013, szp. 341. W przypadku pierwszego ze wspomnianych tu fragmentów (VII) na jeden przekaz rękopiśmienny złożony z dwóch fizycznie zachowanych urywków (17 i 17 wersów) nakłada się częściowo drugi, tym razem zwarty (67 wersów), zapełniający lukę z tego pierwszego o rozmiarach 9 wersów. W drugim fragmencie (VIII) mamy do czynienia z sytuacją, kiedy jedna zwarta, krótka partia tekstowa (17 wersów na 140 wersów całego fragmentu, nie licząc urywków 17 innych wersów) zachowała się w obu przekazach; zob. dokładne omówienie przekazów rękopiśmiennych poszczególnych fragmentów poniżej.

7 Podana przez G. Vollmann-Profe, Wigand von Marburg, szp. 1659, liczba 645 zachowanych fragmentów wynika z błędnego rachunku (zob. też przyp. 19). Po dodaniu do wskazanych tu łącznie 630 fragmentów jeszcze fragmentów końcówek 6 wersów (zob. tabelę poniżej) otrzymujemy sumę 636.

${ }^{8}$ Zob. tabelę poniżej; ponadto Th. Hirsch, Einleitung, s. 442 (u niego odpowiednio fragmenty: II, III, VII, VIII i IX).

9 Zob. tabelę poniżej. 
wyżej dwa fragmenty (VII i VIII) dostępne są częściowo w dwóch różnych przekazach rękopiśmiennych. Pierwszy z nich, z którego zachowało się znacznie więcej fragmentów, można sygnować literą A (kolejno fragmenty: I, IV, V, VI, znaczna część VII i VIII), drugi - odpowiednio jako B (dwa urywki fragmentu VII i urywek fragmentu VIII). Interpretację o pochodzeniu części fragmentów z jednej podstawy rękopiśmiennej, tzw. rękopisu A, przedstawił w 1935 r. Herbert Thoma, datując nieistniejący dziś kodeks na przełom XIV i XV w. ${ }^{10}$, a jego spostrzeżenia powtórzyli w $1968 \mathrm{r}$. Walther Hubatsch i Udo Arnold $^{11}$. Innej części fragmentów Karl A. Barack przypisał już w 1867 r. pochodzenie z odrębnego przekazu rękopiśmiennego, tzw. rękopisu B, uznając go za pochodzący z XV w., a zatem młodszy od rękopisu $\mathrm{A}^{12}$. W nowszej literaturze przedmiotu ustalenia te słusznie nie są podważane ${ }^{13}$. Miejsca odnajdywania poszczególnych ułomków obu rękopisów ${ }^{14}$ skłaniały badaczy do wyrażania opinii o środkowoniemieckiej proweniencji tych podstaw rękopiśmiennych, przy czym niezależnie od jednoznacznego rozstrzygnięcia tej kwestii podkreśla się przede wszystkim ich jednakowe pochodzenie geograficzne ${ }^{15}$. Skrupulatne analizy filologiczne mogłyby rzucić nieco więcej światła w tej kwestii, ale dotychczas ich nie przeprowadzono.

Podstawa rękopiśmienna (raczej chyba tylko jedna) dla pięciu fragmentów opublikowanych w XVI-wiecznych wydaniach kroniki C. Schütza pozostaje nieznana. Z uwagi na fakt, że obydwa późnośredniowieczne przekazy rękopiśmienne pochodzą prawdopodobnie z obszarów środkowoniemieckich ${ }^{16}$, wypada zakładać, że gdański dziejopisarz w pracach nad kroniką prowadzonych w latach 80. i 90. XVI w. korzystał z jeszcze innego rękopisu kroniki Wiganda z Marburga ${ }^{17}$. Tę nieznaną dziś podstawę rękopiśmienną można oznaczyć literą C.

Pozostaje dość prawdopodobne, że tłumacz rymowanego dzieła, Konrad Gesselen, miał w 1464 r. do dyspozycji kolejną kopię kroniki, być może pochodzącą z dawnego toruńskiego konwentu zakonu niemieckiego (zlikwidowanego w 1454 r.), jednak hipotezy tej nie da się w żaden sposób zweryfikować. Th. Hirsch zauważył ponadto, że Stenzel (Stanisław) Bornbach wykorzystywał w swojej kronice egzemplarz dzieła Wigandowego kończący się na 1393 r. (ściślej na śmierci Konrada von Wallenrode 25 lipca tegoż roku), który nie obejmował dopisanego w 1394 r. dodatku ${ }^{18}$. Ów przechowywany w Prusach rękopis kroniki w jej pierwotnej (krótszej) redakcji nie mógł być tożsamy z rękopisem, z którego korzystał Konrad Gesselen, jego thumaczenie dotyczy bowiem redakcji dłuższej, zawierającej wspomniany dodatek. Sumując powyższe rozważania, moglibyśmy doliczyć się przynajmniej pięciu rękopisów oryginalnego dzieła Marburczyka (w tym jednego przekazu krótszej redakcji). Jedynie gwoli formalnego dopełnienia opisu przekazów źródłowych kroniki należy wspomnieć, że nieznany jest jakikolwiek fragment rękopisu-autografu tego dzieła w jego pełnej redakcji, o ile taki w ogóle istniał.

Przejść teraz należy do opisu zewnętrznego przekazów rękopiśmiennych, które wchodziły w skład rękopisów A i B. Jest to łącznie pięć fizycznych fragmentów rękopiśmiennych podanych tu w kolejności treściowej kroniki.

${ }^{10}$ H. Thoma, Ein neues Bruchstück, s. 39-40, 41.

11 Wigand (H/A), s. 44.

${ }^{12}$ K.A. Barack, Bruchstücke aus Wigand von Marburg Reimchronik, „Germania”, 12, 1867, s. 197; za nim podobnie H. Thoma, Ein neues Bruchstück, s. 40, przyp. 3.

${ }_{13}$ Zob. też G. Vollmann-Profe, Wigand von Marburg, szp. 1659-1660; M. Malm, Wigand von Marburg, szp. 342.

${ }^{14}$ Zob. tabelę poniżej.

${ }^{15}$ L. Wolff, Wigand von Marburg, w: Die Deutsche Literatur des Mittelalters. Verfasserlexikon, t. 4, red. K. Langosch, Berlin 1953, szp. 964; G. Vollmann-Profe, Wigand von Marburg, szp. 1660, 1662.

${ }_{16}$ Zob. G. Vollmann-Profe, Wigand von Marburg, szp. 1662.

17 Inaczej sugerowali W. Hubatsch i U. Arnold (zob. Wigand (H/A), s. 44), ale wydaje się to mało prawdopodobne mimo identycznej lekcji Beyorn występującej w rękopisie A i w autografie Konrada Gesselena, zob. poniżej Fragment I, w. 23; Wigand $(\mathrm{H})$, s. 493 = Wigand $(\mathrm{Z} / \mathrm{K})$, s. 204.

18 Th. Hirsch, Einleitung, s. 451. 


\section{Rekonstruowany rękopis A}

1. Fragment rękopiśmienny - Wiedeń, Deutsch-Ordenszentralarchiv, Hs. $565^{19}$ : jest to jeden arkusz pergaminowy złożony na pół i tworzący dwie karty (cztery strony: 1r-2v) o wymiarach $14,8 \mathrm{~cm}$ szer. $\times$ 20,7 cm wys. każda, karty nienumerowane. Arkusz zawiera tekst o łącznej objętości 124 wersów (fragment I), na każdą stronę przypada 31 wersów, które wpisane zostały w liniowane szpalty o wymiarach 9,2-9,3 cm szer. $\times 15,4-15,7 \mathrm{~cm}$ wys. Tekst zapisany na $\mathrm{k}$. $2 \mathrm{r}-2 \mathrm{v}$ jest kontynuacją tekstu $\mathrm{z} \mathrm{k} .1 \mathrm{r}-1 \mathrm{v}$, co oznacza, że arkusz zajmował pierwsze (wierzchnie) miejsce w składce kodeksu. Pierwsze litery wersów są bez wyjątku majuskulne, zdobione czerwonym atramentem, brak rozbudowanych zdobień inicjalnych, co drugi wers przesunięty jest nieco w prawo. Tekst wpisany czarnym atramentem typową XIV-wieczną gotycką teksturą. Późniejsze noty: 1r: na górnym marginesie, ręką XVI-wieczną - Constitution des Cap(ite)ls zu Franckfurtt / Anno 1529; na prawym marginesie, ręką wczesnonowożytną - Nro i 5; na dolnym marginesie, ręką wczesnonowożytną - $N^{o} j$ in fasc. $j$ A lat. $95^{\text {us }}$ / Cist $N$; w samym prawym dolnym rogu, ręką wczesnonowożytną - Originalia / Altzhauß(en); 2r: w prawym górnym rogu naniesiona ołówkiem paginacja: 2; 2v: na górnym marginesie, ręką XVI-wieczną - Constitution Anno 1529; na lewym marginesie naklejony numer 565; na dolnym marginesie, ręką XIX-wieczną - Handschrift 565.

2. Fragment rękopiśmienny - Monachium, Bayerische Staatsbibliothek, Cod. germ. 5249/24m ${ }^{20}$ : jest to jeden arkusz pergaminowy pierwotnie złożony na pół i tworzący dwie karty (cztery strony: 1r-2v), obecnie zaś traktowany jako jedna karta, której strony recto i verso zostały współcześnie mylnie określone, bez uwzględnienia kolejności wynikającej z treści zapisów (współczesna strona recto odpowiada zatem paginacji $1 \mathrm{v}-2 \mathrm{r}$, strona verso zaś paginacji $2 \mathrm{v}-1 \mathrm{r}$ ). Na współczesnej stronie recto na górnym marginesie pośrodku naniesiona ołówkiem sygnatura: Cgm 5249/24m. Karta druga (po rozłożeniu prawa, 2r-v) zachowała się mniej więcej w połowie pierwotnej szerokości, obydwie karty ucięte zostały również od dołu, współczesne wymiary kart arkusza: 13,4-13,9 (k. 1r-1v) i 6,4 (k. 2r-2v) cm szer. $\times 14,9-15,2 \mathrm{~cm}$ wys., co w przypadku całego arkusza daje 19,8-20,3 cm szer. $\times 14,6-15,2 \mathrm{~cm}$ wys. Brak numeracji kart (w niniejszej edycji przyjęto numerację nadaną przez pierwszego wydawcę H. Thomę, zgodną z kolejnością treści zapisów). Arkusz zawiera dwa fragmenty tekstu o łącznej objętości 58 niemal pełnych wersów (fragment IV) na k. 1r-1v (na każdej stronie brakuje po 2 lub 3 wersy) oraz urywków 57 wersów (fragment V) na k. 2r-2v. Pierwotnie na każdą stronę przypadało 31 wersów (zachowanych jest po 29 lub 28 wersów bądź ich urywków), które wpisane zostały w liniowane szpalty o wymiarach $9,1 \mathrm{~cm}$ szer. $\times$ prawdopodobnie ok. 15-15,5 cm wys. Tekst na k. $2 \mathrm{r}$ nie jest kontynuacją fragmentu zapisanego na k. 1r-1v, co oznacza, że arkusz znajdował się wewnątrz składki kodeksu (stąd podział treści zapisów na dwa odrębne fragmenty narracyjne). Pierwsze litery wersów na k. 1r-2r są bez wyjątku majuskulne, zdobione czerwonym atramentem, brak rozbudowanych zdobień inicjalnych. Tekst wpisany czarnym atramentem, gotycką teksturą z końca XIV w.

19 Zob. tamże, s. 441-442; F. Lackner, współpr. A. Haidinger, Katalog der Streubestände in Wien und Niederösterreich, cz. 1: Nichtarchivalische mittelalterliche Handschriften und Fragmente in Korneuburg, Mistelbach, Retz, St. Pölten, Tulln, Waidhofen an der Thaya, Weitra, Wien, Wiener Neustadt und aus Privatbesitz. Katalogband und CD-ROM, Österreichische Akademie der Wissenschaften, Phil.-Hist. Klasse, Denkschriften, t. 272, Veröffentlichungen der Kommission für Schrift- und Buchwesen des Mittelalters, seria II, t. 5, Wien 2000, s. 334, nr 77; zob. też Handschriftenbeschreibung 2068, w: Handschriftencensus. Eine Bestandsaufnahme der handschriftlichen Überlieferung deutschsprachiger Texte des Mittelalters, <https:// handschriftencensus.de/2068> [dostęp: 22.03.2020]; <https://manuscripta.at/hs_detail.php?ID=1667> [dostęp: 22.03.2020]; czarno-białe zdjęcie strony recto arkusza $(2 \mathrm{v} / 1 \mathrm{r})$ : $<\mathrm{https} / /$ manuscripta.at/images/AT/7980/AT7980-565/AT7980-565_r.jpg > [dostęp: 22.03.2020]; czarno-białe zdjęcie strony verso arkusza (1v/2r): <https://manuscripta.at/images/AT/7980/AT7980565/AT7980-565_v.jpg> [dostęp: 22.03.2020].

20 Zob. H. Thoma, Ein neues Bruchstück, s. 39-40; Wigand (H/A), s. 44-45; K. Schneider, Die deutschen Handschriften der Bayerischen Staatsbibliothek München. Die mittelalterlichen Fragmente Cgm 5249-5250, Catalogus codicum manu scriptorum Bibliothecae Monacensis, t. 5, cz. 8, Wiesbaden 2005, s. 60 (<http://bilder.manuscripta-mediaevalia.de/hs//katalogseiten/ HSK0576 a060 jpg.htm> [dostęp: 20.03.2020]); Handschriftenbeschreibung 2068; dwa kolorowe zdjęcia stron recto $(2 \mathrm{v} /$ 1r) i verso arkusza (1v/2r): <https://daten.digitale-sammlungen.de/ db/0013/bsb00134742/images/> [dostęp: 22.03.2020]. 
3. Fragment rękopiśmienny - Karlsruhe, Badische Landesbibliothek, Cod. Donaueschingen A III 9, Fragm. $\mathrm{A}^{21}$ : jest to jeden arkusz pergaminowy złożony na pół i tworzący dwie karty (cztery strony, $1 \mathrm{r}-2 \mathrm{v}$ ). Od góry arkusz został przycięty, podobnie jak obydwa rogi bocznej krawędzi; wymiary kart: 14,8 cm szer. $\times 18,5-18,8 \mathrm{~cm}$ wys.; brak numeracji kart (w niniejszej edycji przyjęto numerację nadaną przez Th. Hirscha). Arkusz zawiera fragment tekstu (fragment VI) na k. 1r-1v o łącznej objętości 67 wersów oraz drugi fragment (część fragmentu VII, w. 8-74) na k. 2r-2v, w obu fragmentach na stronach recto zapisano po 34 wersy, na stronach verso zaś po 33 wersy. Na każdej ze stron jedynie pierwsze dwa wersy zostały wpisane w liniowane wersety o szerokości $9,0 \mathrm{~cm}$. Tekst na $\mathrm{k}$. $2 \mathrm{r}$ nie jest kontynuacją fragmentu zapisanego na k. $1 \mathrm{r}-1 \mathrm{v}$, co oznacza, że arkusz znajdował się wewnątrz składki kodeksu (stąd podział na dwa odrębne fragmenty narracyjne). Pierwsze litery wersów są bez wyjątku majuskulne, zdobione czerwonym atramentem, brak rozbudowanych zdobień inicjalnych, co drugi wers przesunięty nieco w prawo. Tekst wpisany czarnym atramentem, gotycką teksturą z końca XIV bądź z pierwszej połowy XV w. Na k. 1v i 2r miejscami dość mocno wytarty, aczkolwiek nadal czytelny, wytarcia są skutkiem wtórnego zastosowania arkusza po zmakulaturowaniu ok. 1570-1580 r. pierwotnego kodeksu, do którego należał, jako okładki, na co wskazują negatywy odbitych liter w dolnej partii k. $2 \mathrm{v}$ i $1 \mathrm{r}$ (tj. strony recto arkusza); na stronie verso arkusza (k. 1v-2r) pośrodku, w górnej partii XVI-wieczny zapis: Grund des Catholischen glaubens darinnen 63 vrsachen begriffen, daz man Catholisch sein oder werden soll [...] Casparii [...] Francks wskazujący na tytuł dzieła, które zostało $\mathrm{w}$ ten arkusz oprawione ${ }^{22}$. Na prawym marginesie k. 1r naniesiony ołówkiem zapis: $A$ 1, na prawym marginesie k. 2r naniesiona ołówkiem paginacja: 2 .

4. Fragment rękopiśmienny - Karlsruhe, Badische Landesbibliothek, Cod. Donaueschingen A III 9, Fragm. $\mathrm{B}^{23}$ : jest to jeden arkusz pergaminowy złożony na pół i tworzący dwie karty (cztery strony, $1 \mathrm{r}-2 \mathrm{v})$. Obydwa rogi bocznej krawędzi zostały przycięte, wymiary kart: $14,8 \mathrm{~cm}$ szer. $\times 20,5-21,0 \mathrm{~cm}$ wys., brak numeracji kart (w niniejszej edycji przyjęto numerację nadaną przez Th. Hirscha). Arkusz zawiera fragment tekstu kroniki (fragment VIII) o objętości 140 wersów, na każdej ze stron zapisano po 35 wersów, wszystkie wersy wpisane zostały w liniowane szpalty o wymiarach $9,2 \mathrm{~cm}$ szer. $\times$ 16,2-16,6 cm wys. Tekst zapisany na k. 2r-2v jest kontynuacją tekstu z k. 1r-1v, co oznacza, że arkusz zajmował pierwsze (wierzchnie) miejsce w jednej ze składek kodeksu. Pierwsze litery wersów są bez wyjątku majuskulne, zdobione czerwonym atramentem, brak rozbudowanych zdobień inicjalnych, co drugi wers przesunięty nieco w prawo. Tekst wpisany czarnym atramentem, gotycką teksturą z końca XIV bądź z pierwszej połowy XV w. Na k. 1r tekst miejscami wytarty, aczkolwiek nadal czytelny. Na k. 1r, 1v i 2r widać ślady (negatywy liter) książki, dla której arkusz posłużył po zmakulaturowaniu ok. 1570-1580 r. wtórnie jako okładka. Na stronie verso arkusza (k. 1v-2r) pośrodku, w górnej partii

${ }^{21}$ K.A. Barack, Bruchstücke, s. 196-197; Wigand (H:ZF), s. 1-2; H. Kienhorst, Lering en stichting op klein formaat. Middelnederlandse rijmteksten in eenkolomsboekjes van perkament, t. 2: Handschriften, Miscellanea Neerlandica, t. 32, Leuven 2005, s. 348-349 (D28); N. Eichenberger, Ch. Mackert, Überarbeitung und Online-Publikation der Erschließungsergebnisse aus dem DFG-Projekt zur Neukatalogisierung der ehemals Donaueschinger Handschriften in der Badischen Landesbibliothek Karlsruhe, unter Mitarbeit von Ute Obhof sowie unter Einbeziehung von Vorarbeiten von Wolfgang Runschke und Sabine Lütkemeyer [Beschreibungen via Manuscripta Mediaevalia], <http://www.manuscripta-mediaevalia.de/?xdbdtdn!\%22obj\%20 31577285\%22\&dmode=doc\#|4> [dostęp: 22.03.2020]; Handschriftenbeschreibung 2068; kolorowe zdjęcie strony recto arkusza (2v/1r): <http://www.zfda.de/images/pic_karl_donaiii9a_2v1r.jpg> [dostęp: 22.03.2020]; kolorowe zdjęcie strony verso arkusza (1v/2r): <http://www.zfda.de/images/pic_karl_donaiii9a_1v2r.jpg> [dostęp: 22.03.2020].

${ }^{22}$ Chodzi o: K. Franck, Grundt des Catholischen Glaubens/Darinnen drey vnnd sechtzig Vrsachen begriffen/ warumb alle rechtglaubige Christen/ bey der allgemainen/Christlichen vnd Römischen Kirchen/biß an jhr endt zuuerharren schuldig seyn [...], Ingolstadt 1580 .

${ }^{23}$ K.A. Barack, Bruchstücke, s. 196-197; Wigand (H:ZF), s. 1-2; H. Kienhorst, Lering en stichting op klein formaat, s. 348-349 (D28); N. Eichenberger, Ch. Mackert, Überarbeitung und Online-Publikation; Handschriftenbeschreibung 2068; kolorowe zdjęcie strony recto $\operatorname{arkusza}(2 \mathrm{v} / 1 \mathrm{r})$ : <http://www.zfda.de/images/pic_karl_donaiii9b_2v1r.jpg.> [dostęp: 22.03.2020]; kolorowe zdjęcie strony verso arkusza (1v/2r): <http://www.zfda.de/images/pic_karl_donaiii9b_1v2r.jpg $>$ [dostęp: 22.03.2020]. 
XVI-wieczne zapisy: Antwort auf Brentzen Testam[ent] / Antwort auf Doct. Schmiedlius Wiederlegen / Ant[wort] auf die VII klag-Artic[kel] ${ }^{24}$. Na prawym marginesie k. 1r naniesiony ołówkiem zapis: $B$ 1; na prawym marginesie k. 2r naniesiona ołówkiem paginacja: 2.

\section{Rekonstruowany rękopis $B$}

1. Fragment rękopiśmienny - Karlsruhe, Badische Landesbibliothek, Cod. Donaueschingen A III $10^{25}$ : jest to fragment arkusza pergaminowego złożonego $\mathrm{z}$ dwóch kart (czterech stron, 1r-2v). Obydwie karty zostały przycięte około połowy pierwotnej wysokości, obecne wymiary k. $1 \mathrm{r}-1 \mathrm{v}$ : $13,0-13,2 \mathrm{~cm}$ szer. $\times$ 9,9-10,4 cm wys.; k. 2r-2v ucięta została również w pionie, tak że został z niej skrawek pergaminowy obecnie o wymiarach 4,3-4,6 cm szer. $\times 9,5-10,1 \mathrm{~cm}$ wys.; wymiary całego arkusza: 17,3-17,6 cm szer. $\times$ 9,5-10,4 cm wys. Na k. 1r zapisanych zostało 17 wersów (początek fragmentu VII, w. 1-17, przy czym wersy 1-7 zachowane są jedynie w tej podstawie rękopiśmiennej, wersy 8-17 są zaś znane także z rękopisu A (Karlsruhe, Badische Landesbibliothek, Cod. Donaueschingen A III 9, Fragm. A, k. 2r). Pierwotnie na całej stronie, jak wynika z zestawienia $\mathrm{z}$ wersami z rekonstruowanego rękopisu A, znajdowało się 26 wersów; na k. 1v zachowało się kolejnych 17 wersów fragmentu VII (w. 27-43), które w całości znane są z rękopisu A (Karlsruhe, Badische Landesbibliothek, Cod. Donaueschingen A III 9, Fragm. A, k. 2r-2v); na k. 2r zachowały się urywki (początki) 17 wersów fragmentu VIII (w. 46-62), które w całości znane są z rękopisu A (Karlsruhe, Badische Landesbibliotek, Cod. Donaueschingen A III 9, Fragm. B, k. 1v); na k. 2v zachowały się skrawki (końcówki) 6 spośród zapewne 17 wersów zapisanych pierwotnie, które daje się zidentyfikować jako końcówki kolejno wersów: 73, 78, 79, 81, 83 i $84^{26}$. Tekst na k. 2r nie jest kontynuacją fragmentu zapisanego na k. 1r-1v, co oznacza, że arkusz znajdował się wewnątrz składki kodeksu. Na k. 1r-2r tekst jest nieliniowany. Pierwsze litery wersów są bez wyjątku majuskulne, zdobione czerwonym atramentem, brak rozbudowanych zdobień inicjalnych, co drugi wers przesunięty nieco w prawo. Tekst wpisany czarnym atramentem, gotycką teksturą zapewne nieco młodszą w stosunku do pisma z rekonstruowanego rękopisu A, z pierwszej połowy XV w.

Pełne zestawienie fragmentów oryginalnych kroniki wraz z ich omówionymi wyżej przekazami rękopiśmiennymi (oraz przekazem drukowanym C), odkrywcami, miejscami obecnego przechowywania oraz ich dotychczasowymi edycjami przedstawia poniższa tabela:

${ }^{24}$ Chodzi o dwa dzieła Heinricha Bullingera: tenże, Vff Herren Johannsen Brentzen Testament kurtzlich durch den truck wider die Zwinglianer vßgangen [...], Zürich 1571; tenże, Antwort Der Dieneren der Kyrchen zü Zürich vff D. Jacoben Anderessen/ zügenampt Schmidly/ Widerlegen [...], Zürich 1575.

${ }^{25}$ Th. Hirsch, Einleitung, s. 442; N. Eichenberger, Ch. Mackert, Überarbeitung und Online-Publikation; Handschriftenbeschreibung 2067, w: Handschriftencensus. Eine Bestandsaufnahme der handschriftlichen Überlieferung deutschsprachiger Texte des Mittelalters, <https://handschriftencensus.de/2067> [dostęp: 22.03.2020]; kolorowe zdjęcie k. 1r: <http://www. zfda.de/images/pic_karl_donaiii10_1r.jpg> [dostęp: 22.03.2020]; kolorowe zdjęcie k. 1v-2r: <http://www.zfda.de/images/ pic_karl_donaiii10_1v2r.jpg > [dostęp: 22.03.2020]; kolorowe zdjęcie k. 2v: <http://www.zfda.de/images/pic_karl_donaiii10_2v. jpg> [dostęp: 22.03.2020].

${ }^{26}$ Zob. tabelę poniżej. 


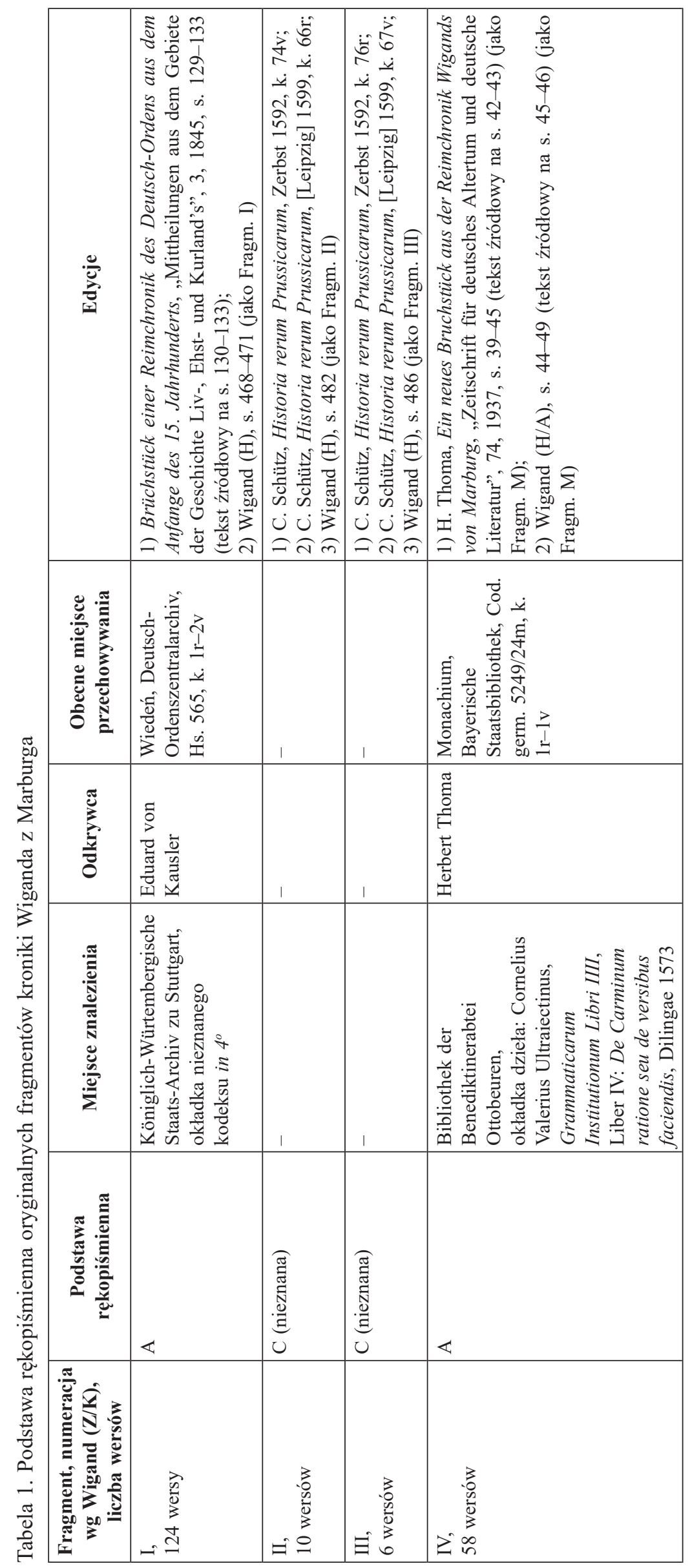









\begin{tabular}{|c|c|c|c|c|c|c|c|}
\hline$\underset{\substack{0 \\
:}}{\stackrel{0}{c}}$ & 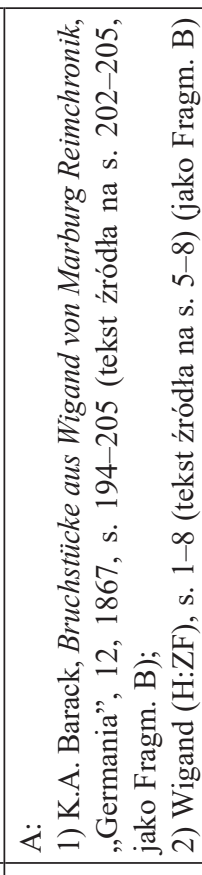 & 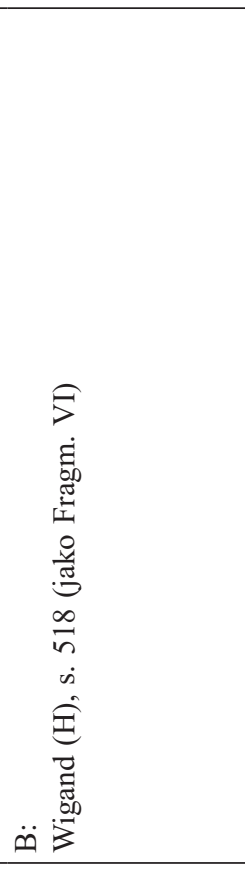 & $\ddot{\oplus} \mid$ & 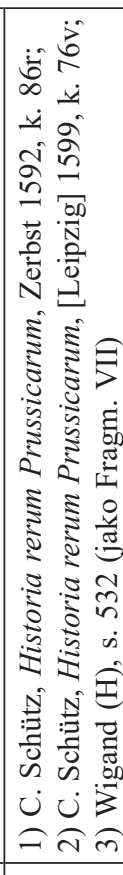 & 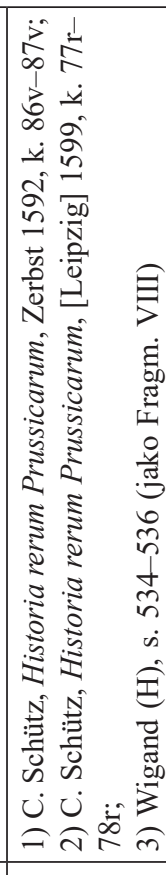 & 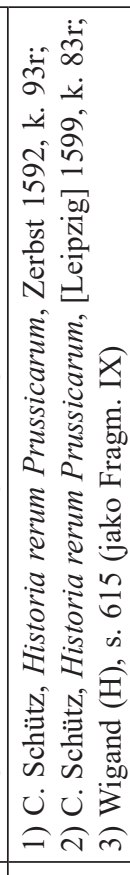 & 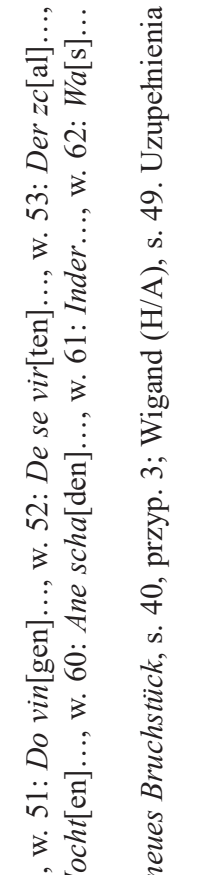 \\
\hline 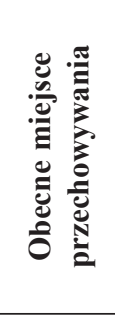 & 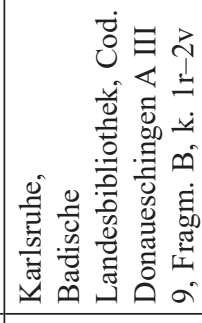 &  & 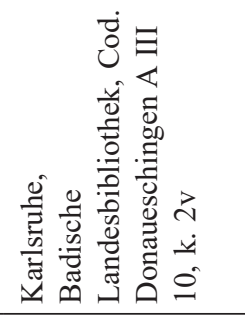 & 1 & 1 & 1 & 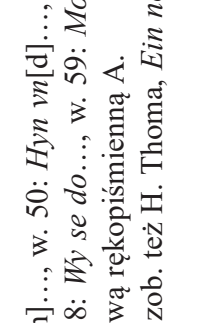 \\
\hline 遶 & 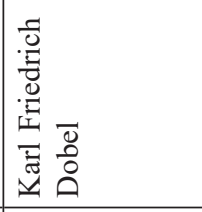 & 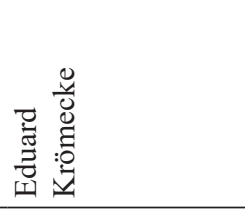 & 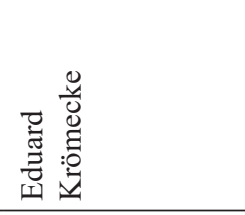 & 1 & I & 1 &  \\
\hline 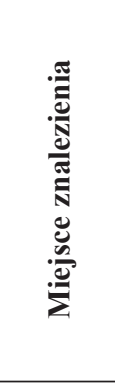 & 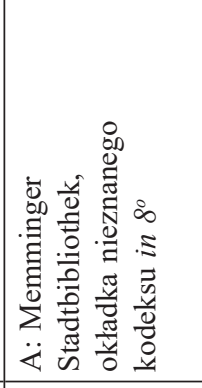 & 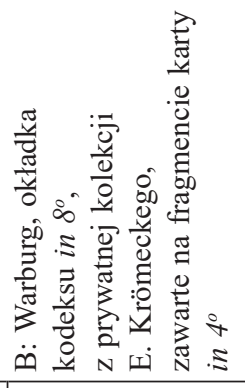 &  & 1 & 1 & 1 &  \\
\hline \multirow{2}{*}{ 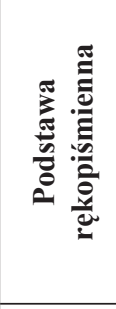 } & & 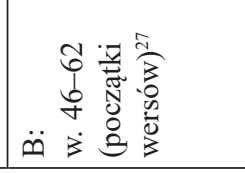 & 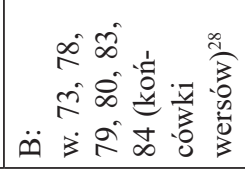 & \multirow{2}{*}{ 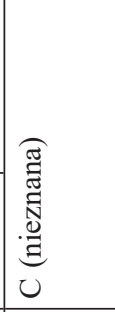 } & \multirow{2}{*}{  } & \multirow{2}{*}{ 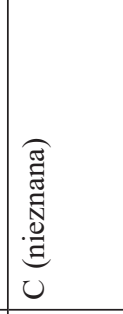 } & 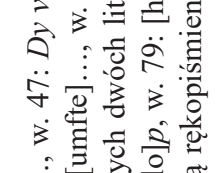 \\
\hline & $\begin{array}{l}39 \\
3 \\
\ddot{4} I\end{array}$ & & & & & & 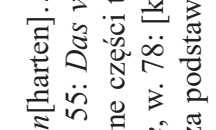 \\
\hline  & 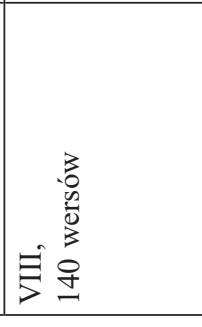 & & & 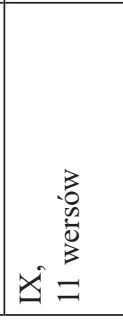 & 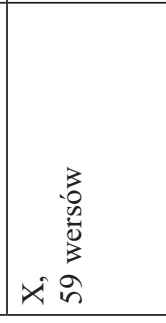 & 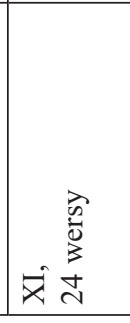 &  \\
\hline
\end{tabular}




\section{Zasady edycji}

W przedstawionej poniżej edycji źródłowej tekst został oddany wiernie bez żadnych ingerencji w zakresie pisowni wielkich i małych liter, interpunkcji czy znaków diakrytycznych. Ulepszone pod względem językowym poprawki poprzednich wydawców nie zostały uwzględnione (z wyjątkiem koniektur zmieniających sens tekstu), nie odnoszą się bowiem one do lekcji rękopiśmiennych. Te ostatnie, możliwe do wskazania jedynie w przypadku trzech ustępów przekazanych w obu rekonstruowanych kodeksach A i B (łącznie 27 wersów fragmentu VII [w. 8-17 i 27-43] oraz urywki 17 wersów fragmentu VIII [w. 46-62] $)^{29}$, podano w przypisach edytorskich, za punkt odniesienia przyjmując zachowane urywki rękopisu A. Uwaga dotycząca koniektur i emendacji w największym stopniu odnosi się do działań edytorskich Th. Hirscha ${ }^{30}$, który niekiedy znacznie ingerował we fleksję, a zwłaszcza stosował znaki diakrytyczne na oznaczenie długich samogłosek: „ầ, „ề”, „,̂”, „ô”, „û". Nawet w przypadku majuskulnej i minuskulnej litery „," nie zdecydowano się na oddawanie jej rzeczywistej wartości fonetycznej (jako „V” bądź „u”), pozostawiając zapis oryginalny. Rozwinięcia stosunkowo nielicznych abrewiacji podano w nawiasach okrągłych ( ), a wszelkie uzupełnienia lub propozycje uzupełnień w nawiasach kwadratowych [...]. Liczba kropek w tego rodzaju nawiasach w tekście źródłowym nie oznacza liczby brakujących liter, jej określenie było bowiem niemożliwe. Uwzględniono również odmianki tekstu zawarte w drugiej edycji dzieła C. Schütza z 1599 r., za punkt odniesienia biorąc wydanie pierwsze z 1592 r. W zapisie oryginalnego tekstu średnio-górno-niemieckiego przy pomocy pojedynczego ukośnika (/) oznaczono delimitację kart rękopiśmiennych, a podwójnym ukośnikiem (//) delimitację stron dotychczasowych edycji (w przypadku większej liczby wydań uwzględniono tylko jedno, najlepsze). W sytuacji, kiedy chodziło o zamknięty urywek (czy to tekstu źródłowego, czy edycji) w obrębie danego fragmentu jego zasięg oznaczano przy pomocy znaków: /-- --/ i //-- --//. W celu ułatwienia ścisłego cytowania wprowadzono również numerację wersów (oznaczoną numerami arabskimi podawanymi z częstotliwością co pięć).

Przyjętą zasadą thumaczenia wierszowanego utworu kronikarskiego na język polski podanego paralelnie $\mathrm{z}$ tekstem oryginalnym $\mathrm{w}$ drugiej kolumnie było dążenie do możliwie adekwatnego oddania semantyki słów i wyrażeń oraz płaszczyzny treściowej tekstu, istotnej z punktu widzenia historyka, co oczywiście musiało odbić się niekorzystnie na warstwie stylistycznej, nie wspominając już o rytmice i rymach. W przekładzie wprowadzono oczywistą pisownię wielkich i małych liter zgodnie ze współczesnymi zasadami ortografii, jak również zastosowano współczesną interpunkcję, aczkolwiek ta ostatnia ingerencja nierzadko miała charakter interpretacji dynamiki rymowanego tekstu oryginalnego. W nawiasach kwadratowych [ ] podano uzupełnienia rozjaśniające sens oraz wszelkie thumaczenia proponowanych uzupełnień w tekście oryginalnym. Z kolei w cudzysłowach ostrokątnych tzw. niemieckich (»«) ujęto repliki dialogowe, dokonując tego zabiegu dla ułatwienia odbioru polskiego tekstu. Kursywą zapisano te nazwy własne, których identyfikacja ich geograficznych denotatów jest niemożliwa, a więc mają one status wersji źródłowych. Gdy wystąpiły one w przypadku zależnym, kursywą podawano jedynie formę mianownikową. Przypisy rzeczowe w polskim tłumaczeniu służą objaśnieniu nazw toponimicznych i występujących w tekście osób. Stosowano je również wszędzie tam, gdzie proponowane tłumaczenie wymagało uzasadnienia, rozjaśnienia sensu tudzież uwzględnienia emendacji i koniektur bądź propozycji interpretacyjnych poprzednich wydawców. Nie mają one bynajmniej charakteru wyczerpujących komentarzy źródłoznawczych czy historycznych, jako że nie było moim zamiarem opracowywanie w tym miejscu rozbioru krytycznego źródła.

Dla ułatwienia lokalizacji danego fragmentu oryginalnego względem tekstu łacińskiego przekładu Konrada Gesselena w trzeciej kolumnie podano ten ostatni w wersji zaczerpniętej z edycji z 2017 r. $^{31}$

\footnotetext{
${ }^{29}$ G. Vollmann-Profe, Wigand von Marburg, szp. 1659, błędnie pisała o 51 wersach zachowanych w więcej niż jednym przekazie rękopiśmiennym.

${ }^{30}$ Zob. Wigand (H), s. 468, przyp. a; s. 482, przyp. a; s. 486, przyp. *.

31 Zob. przyp. 1.
} 
Oznaczono w nim również delimitację stron tej edycji, zapisując ją w potrójnych ukośnikach (///), a w nawiasach klamrowych \{ \} oznaczono przypisane przez wydawców numery całostek narracyjnych wydzielonych przez Konrada Gesselena. Zastosowane w tym tekście wielokropki w nawiasach zapisane kursywą [...] oznaczają nagłe początki i zakończenia poszczególnych urywków łacińskich odpowiadających fragmentom oryginalnym, podczas gdy wielokropki w nawiasach zapisane tekstem prostym [...] w tekście łacińskim odpowiadającym Fragmentowi XI wskazują na wyjątki z dłuższego tekstu Konrada Gesselena, a to z uwagi na fakt, że w tym miejscu tłumaczenie łacińskie zawiera elementy treściowe nieobecne w średnio-górno-niemieckim oryginale, a więc jest względem niego obszerniejsze.

\section{Edycja i tlumaczenie}

\section{Fragment I}

Podstawa rękopiśmienna: rekonstruowany rkps A: Wiedeń, Deutsch-Ordenszentralarchiv, Hs. 565, k. 1r-2v.

Treść: fragment dotyczy ataku wojska wielkiego księcia Litwy Giedymina na Prusy latem 1330 r. oraz równoczesnych działań króla Polski Władysława I Łokietka w ziemi dobrzyńskiej, w rejonie ujścia Drwęcy do Wisły.

\section{Oryginal}

/k. $1 r / / / W i g a n d(H)$, s. $468 / /$

Daz di heidenische schar

Hatte si belegen do

Von der littow heer also

Mit mancher hande grose not

${ }^{5}$ Dy en der heiden konig bot

Mit stormen ouch gar herte

Vnd mancherhande geverte

Vnser herre got vor hinc

Daz bruder Johan do vinc

${ }^{10}$ Der heiden vil genuk

Dy er vmbermlich irsluk

Vf dy heiden was er gram

Dy virczik man alzam

Vil der pherde nomen

${ }^{15}$ Wol noch erem vromen

Das si kvme gefuren kvnde

Von dannen czu d(er)selben stunde

Dy heẏden wanten also

Das eyn gros her were do
Laciński tekst tlumaczenia

Konrada Gesselena

[tak] że zastęp pogański

ich $^{1}$ tam oblegt,

przez co też wojsko Litwinów

w przemożnie ${ }^{2}$ wielkiej ${ }^{3}$ potrzebie,

${ }^{5}$ którą im zgotował król pogan,

szturmowało ${ }^{4}$ całkiem mocno

w różnorodny sposób.

Nasz Pan Bóg zrządził,

że brat Johann ${ }^{5}$ schwytał tam

${ }^{10}$ dość wielu ${ }^{6}$ pogan,

których bez zmiłowania wybił.

Był on zawzięty na pogan,

40 ludzi łącznie

pochwyciło wiele koni,

${ }^{15}$ pewnie na swój pożytek,

tak że ledwo mogli je uprowadzić

stamtąd, w owej godzinie.

Poganie też zauważyli,

że wielkie wojsko tam ///s. 152/// [...] sed Dominus preservavit cives, et civitas mansit intacta.

\{23\} Advocatus episcopi frater Johannes de Dyr, audita de dicta obsidione et terre Loboviensis vastatione,

in vindictam sumptis secum $\mathrm{xl}$ viris, invasit paganos, qui iussu regis sic impugnabant opidum etc., et ex eis plures crudeliter interfecit, et tot equos accepit, quod vix poterant eos deportare;

unde pagani putabant magnam copiam supervenisse,

${ }^{1}$ W znaczeniu: siły pruskie (chrześcijańskie) w Lubawie (niem. Löbau), co wynika z tekstu tacińskiego tlumaczenia; zob. Wigand (H), s. 467-468.

2 W dosłownym znaczeniu: 'różnorodnej', przy czym przydawkę tę wypada tu rozumieć jako „, wszelaka”, a więc 'ogarniająca wszystko', które to znaczenie lepiej stylistycznie oddaje określenie „przemożny”.

${ }^{3}$ Th. Hirsch proponowat emendację z groze na grôzer, czyli 'większa'; zob. Wigand (H), s. 468, przyp. a.

${ }^{4}$ W znaczeniu: szturmowato Lubawe, zob. przyp. 1.

${ }^{5}$ Chodzi tu o brata zakonu niemieckiego Johanna de Dyr, petniącego wówczas urząd wójta biskupa chetmińskiego, nigdzie indziej niepoświadczonego, którego przydawkę odmiejscowa H proponowat odczytywać jako 'von Trier'; zob. Wigand (H), s. 468, przyp. 92; za nim także K. Gudmantas (zob. Wigand (J/T/G), s. 71) oraz M. Jarzebowski, Die Residenzen der preußischen Bischöfe bis 1525, Prussia Sacra, t. 3, Toruń 2007, s. 450; zob. też Wigand (Z/K), s. 153, przyp. 145.

${ }^{6}$ Th. Hirsch proponowat tu emendację z vil genûk na vil und genûk (zob. Wigand (H), s. 468, przyp. a), która jednak właściwie nie wplywa na thmaczenie, a przy tym jawi się jako watpliwa. 
${ }^{20}$ An si queme mit groser macht Alsus wurden sy dir schrakt Czu hant si mit vlysen Von den stormen lisen Di stat nicht wart gewu(n)nen

${ }^{25}$ Dy heiden von dannen entru(n)ne(n)

An dem andern tage

Czogen vs der selbe(n) sage

Dy heiden mit argen sÿnne(n)

Czu konige Gedemyne

${ }^{30} \mathrm{Czu}$ Kurnỳg reit in daz lant

Von ym wart is do vor brant

/k. $1 v /$ Hỳn vnd her vmme

Dỷ twer vnd di krumme.

Ouch in der selben vart

${ }^{35}$ Was konig gedemŷn gekart

Obir eyn vlies das was bekant

Di Drewancz do genant

//s. 469// Czu der selben czit schow

In das lant czu Mîchilow

${ }^{40}$ Reit konig gedemŷn czu hant

Do stifte er roub vnd brant

Vf der cristen vngewin

Was gestalt gancz syn sín

Mit arger liste ande

${ }^{45} \mathrm{Czu}$ dem genanten lande

By strozeb(e)rg eyne wile

Vf eyne halbe myle

Bynnen den czyten alda

Meister werner von orsla
${ }^{20}$ się ku nim zbliża z wielką mocą.

Do tego stopnia byli przerażeni,

że od razu szybko

porzucili szturmowanie.

Miasto nie zostało zdobyte,

${ }^{25}$ a poganie stamtąd odbiegli.

Następnego dnia ${ }^{7}$

na tąż samą wieść ${ }^{8}$

poganie pociągnęli gniewni

do króla Giedymina ${ }^{9}$.

${ }^{30}$ Wszedł [on] do ziemi kurzętnickiej ${ }^{10}$, przez niego było spalone

[wszystko] wokół tu i tam,

wzdłuż i wszerz.

I w tym samym czasie

król Giedymin zwrócił się

przez pewną rzekę, która pospolicie

nazywała się Drwęca ${ }^{11}$.

W tej samej chwili

do ziemi michałowskiej ${ }^{12}$

${ }^{40}$ ruszył król Giedymin od razu.

Tam rabował i palił

ku nieszczęściu chrześcijan,

- co odpowiadało całkiem jego zamysłom

i chorobliwej chytrości -

${ }^{45}$ we wspomnianym kraju,

niedaleko od Strasburga ${ }^{13}$,

na pół mili14.

$\mathrm{W}$ tym też czasie

mistrz Werner von Orseln ${ }^{15}$,
Konrada Gesselena

dimiserunt impugnaciones et abierunt.

$\{24\}$ Crastina die

de predictis paganis

cum rege Gedemyno

intrant terram Kurnig,

quam hinc inde subverterunt et comburunt.

///s. $154 / / /\{25\}$ Eodem tempore

idem rex

transit flumen Drybantz

in terram Michelaw,

ubi simili

obprobrio christianos perturbavit usque

prope Strosburg

ad medium miliare.

\{26\} Quo cognito magister Wernerus venit de Livonia

7 Chronologia bezwzględna jest tu niemożliwa do ustalenia.

${ }^{8}$ W znaczeniu: że wojsko zakonu niemieckiego się zbliża.

${ }^{9}$ Mowa tu o Giedyminie (lit. Gedyminas) (ur. ok. 1275, zm. XI-XII 1341), prawdopodobnie synu księcia Budiwida (Butywida) i bracie (przyrodnim?) wielkiego księcia Witenesa, wielkim księciu litewskim (1316-1341).

${ }^{10}$ Kurzętnik (niem. Kauernick), osada należąca wówczas do władztwa kapituly chetmińskiej, położona na lewym brzegu środkowej Drwęcy. Trudno jednoznacznie stwierdzić, czy istniał już wówczas znany z późniejszych dekad zamek kapituly (choćby drewniany). Mimo że tekst wskazuje odrębne i niereferencyjne rozumienie toponimu 'Kurzętnik' względem terminu land ('kraj', 'ziemia'), to jednak w kontekście w. 40, 66 i 99 odczytanie tej frazy jako 'ziemia kurzętnicka' wydaje się najprawdopodobniejsze. Tak samo zrozumiat ja w 1464 r. Konrad Gesselen, stosując w przektadzie określenie terra Kurnig (ziemia kurzętnicka). Tym mianem określano zapewne, przynajmniej w końcu XIV w., terytorium będące częścia władztwa kapituty chetmińskiej, którego ośrodkiem zarządu byt Kurzętnik.

${ }^{11}$ Drwęca (niem. Drewanz), prawy dopływ środkowej Wisty uchodzacy do niej pod Złotoria, ok. 5,5 km na wschód od Torunia.

${ }_{12}$ Ziemia michałowska (niem. Michelauer Land), obszar położony na lewym brzegu dolnej Drwęcy, naprzeciwko Brodnicy, między odcinkiem Drwęcy a Brynica oraz Rypienica i rzeka Pisiak.

13 Brodnica (niem. Strasburg), zamek i miasto zakonu niemieckiego położone w ziemi chetmińskiej nad środkowa Drwęcą.

${ }^{14}$ Tj. ok. 3892,5 m liczone wedle miary chetmińskiej, w której łokieć (niem. Elle) liczył w przeliczeniu na system metryczny $57,752 \mathrm{~cm}$, pręt zaś (niem. Rute) mający 7,5 tokcia dawat 433,14 cm (w zaokragleniu 4,32 m); zob. H. Witthöft, Metrologische Überlegungen zur Kulmer Handfeste 1233/51, w: Beiträge zur geschichte des Deutschen Ordens, t. 2, wyd. U. Arnold, Quellen und Studien zur Geschichte des Deutschen Ordens, t. 49; Veröffentlichungen der Internationalen Historischen Kommission zur Erforschung des Deutschen Ordens, t. 5, Marburg 1993, s. 82, przyp. 55 (z przywołaniem starszej literatury).

15 Werner von Orseln (ur. ok. 1285/1290, zm. 19 XI 1330), brat rycerz zakonu niemieckiego, pochodzacy z rodziny wójtów von Ursel z heskiego Taunusu, syn Wernara von Orseln i Kunigundy von Ulfa, sprawujacy urzędy: komtura ragneckiego (\{28 IV 1312\}-1313), wielkiego komtura (\{21 I 1315\}-\{7 IV 1317\} i \{1 VIII 1319\}-6 VII 1324) oraz 17. wielkiego mistrza (6 VII 1324-19 XI 1330). 


\begin{tabular}{l} 
Oryginal \\
\hline${ }^{50}$ a-Al sulche mere wart bekant \\
Das do quam von yflant \\
Der meister mit eynem grosen her \\
Quam geczogen noch lustis ger \\
Bruder wulfram von nellenburc \\
${ }^{55}$ Der kegen dy heyden manche(n) wurg \\
Hatten geton bi sinen ioren \\
Di meister beide czu strazeberg woren \\
Der meister czu dutsche lant was \\
Als ich an dem buche las \\
${ }^{60}$ Von bruma bruder euerhart \\
Meister czu liflant inder vart \\
In dem herbeste man sy sach \\
/ $k$. $2 r /$ Czu straseberg als dry dach \\
Mit eren gebitigern also \\
${ }^{65}$ Dy werhaft weren do \\
Czu prussen indas lant
\end{tabular}

Thumaczenie

Laciński tekst tlumaczenia Konrada Gesselena
${ }^{50}$ kiedy dotarły takie wieści, że przybył z Inflant ${ }^{16}$ mistrz z wielkim wojskiem, przybył, ciągnąc za żądzą przyjemności ${ }^{17}$, brat Wolfram von Nellenburg ${ }^{18}$, ${ }^{55}$ który przeciwko poganom niejednego czynu dokonał w swoich latach.

Obydwaj [ci] mistrzowie byli w Strasburgu: cum multis electis viris in Strosburg, mistrz z kraju niemieckiego ${ }^{19}$, jak przeczytałem w księdze ${ }^{20}$, ${ }^{60}$ brat Eberhard von Bruma ${ }^{21}$, mistrz w Inflantach w tym czasie. Jesienią widziano ich w Strasburgu przez trzy dni, wraz z ich również dostojnikami, ${ }^{65}$ którzy tam pod bronią byli. Do kraju w Prusach ${ }^{22}$ cum fratre Wulveram de Nellenborg, magistro in Teutonia, animoso viro, ubi eciam frater Eberhardus de Bruma, magistro Lyvoniensi visi sunt;

hii 3 magistri cum suis preceptoribus

in Pruszia

a-a Wobec występujących w oznaczonym fragmencie oczywistych niejasności narracyjnych H proponowat nastepujace przestawienie dwóch par rymujacych się wersów: 50,51,60,61,52,53,58,59,54,55,56,57,62, co dawatoby następująca narrację: „, kiedy dotarly takie wieści, /że przybyt z Inflant / brat Eberhard von Bruma, / mistrz w Inflantach, na wyprawie [byt] / mistrz z wielkim wojskiem, / przybyt, ciągnąc za żądza przyjemności, / mistrz z kraju niemieckiego byt, / jak przeczytałem w księdze, / brat Wolfram von Nellenburg, / który przeciwko poganom niejednego czynu / dokonat w swoich latach. / Obydwaj [ci] mistrzowie byli w Strasburgu, / jesieniq widziano ich [...]". Analiza tak skomponowanego tekstu średnio-górno-niemieckiego wykazuje jednak niedające się wyjaśnić problemy stylistyczne, a nawet treściowo-znaczeniowe. Problem pojawiających się w w. 57 „obydwóch mistrzów”, podczas gdy we wcześniejszej narracji (w obu wersjach) pojawiaja się trzej mistrzowie, pozostaje tak czy inaczej nierozwiazany. Wydaje się, że mamy tu do czynienia nie tyle z błędami kopisty, jak sądzit $H$ (zob. Wigand (H), s. 469, przyp. a), ale z pomyłka samego Wiganda von Marburg, który błędnie zrozumiat starsza piśmienna narrację, która miat do dyspozycji i którą - jak sam zaznacza w metatekstowej uwadze (w. 59) - czytat w jakimś kodeksie.

${ }^{16}$ Inflanty (Liwonia, niem. Livland), kraina położona na wschodnim pobrzeżu Morza Bałtyckiego. W XII-XV w. nazwa 'Liwonia' funkcjonowała zarówno w znaczeniu węższym, oznaczając tereny położone $w$ dorzeczu dolnej Dźwiny (głównie leżace na północ od tej rzeki), jak i szerszym, którego desygnatem byty obszary podlegajace władztwu inflanckiej gałęzi zakonu niemieckiego oraz tamtejszych biskupów, arcybiskupa ryskiego i ich kapitut katedralnych.

17 Zapewne w znaczeniu: przyjemności wojennej.

18 Wolfram hrabia von Nellenburg, brat rycerz zakonu niemieckiego, pochodzacy ze szwabskiego rodu von Nellenburg, będacego młodsza linia hrabiowskiego rodu von Veringen i posiadajacego dobra w okolicach Konstancji, piastowat urzędy: komtura w Mainau (1316-1322) oraz landmistrza w krajach Rzeszy (1329/1330-1361).

19 Chodzi tu nie o pojedynczy kraj, lecz o kraje niemieckie, czyli niemieckojęzyczne regiony Rzeszy rzymskiej, aczkolwiek mistrz krajowy zakonu niemieckiego $w$ Rzeszy zarzadzat nie tylko baliwatami $w$ krajach niemieckojęzycznych, ale także frankofońskich i italskich.

${ }^{20}$ Jakkolwiek S. Zoneberg, Kronika Wiganda z Marburga, Bydgoszcz 1994, s. 82, uważat, że Wigand von Marburg zredagowat narrację o wydarzeniach wojennych 1330 r. na podstawie kroniki oliwskiej w redakcji opata Stanisława, brak w tym źródle informacji o letnio-jesiennej wyprawie litewskiej na Prusy oraz o obecności w tym czasie w Prusach landmistrza z krajów Rzeszy, wobec czego przywołany przez Wiganda buch z pewnościa nie mógł być kodeksem zawierajacym kronikę oliwska. Stusznie Th. Hirsch dopatrywał się $w$ tej wzmiance informacji o zaginionym przekazie, niezależnym od znanych źródel, a przy tym znacznie od nich rozleglejszym; zob. Wigand (H), s. 467, przyp. 89*.

${ }^{21}$ Chodzi tu o Eberharda von Monheim (ur. ok. 1274, zm. po 1346), brata rycerza zakonu niemieckiego, pochodzacego $z$ dolnonadreńskiego Monheim położonego w księstwie Bergu; piastowat on urzędy: komtura windawskiego (\{1309-1313\}), komtura gołdyńskiego (\{1327\}-25 V 1328) oraz landmistrza inflanckiego (25 V 1328-24 VI 1340). Po złożeniu urzędu wyjechat z Inflant do baliwatu koblenckiego, w którym przebywał prawdopodobnie do śmierci. Pojawienie się formy 'von Bruma' wypada tlumaczyć chyba jedynie pomytka kopisty.

${ }^{22}$ Typowe ówczesne niemieckojęzyczne określenie Prus: kraj pruski (dost. 'kraj w Prusach'). 


\section{Oryginal}

Eyn capitel wart bekant

Vf den tag des heilige(n) crucis

$/ / s$. 470// Genant exaltacionis

${ }^{70}$ Do den meistern wart bekant

Daz di heiden in das lant

Sich hatten also stark geleit

Keyner ouch von dannen reit

Herten vnd branten

${ }^{75}$ Als das sy ir kanten

Das des ordenes was

Nymant vor yn genas

Meister werner von orsla

Wart mit den andern czu rate do

${ }^{80}$ Das er mit den polen welde striten

Al czu den selben gecziten

Czogen mit eyme here gros

Vf den konig und syn genos

Obir daz wasser Drywancz

${ }^{85}$ Als eyne svnnen glancze

Do dy meister quomen vru

Hen obir mit groser $\mathrm{mv}^{\mathrm{e}}$

Vf daz leger der littouwen

Do sy woren inden ouwen

${ }^{90}$ Dy czit aldo gelegen

Mit manheit wol ir wegen

Do der meister strites begert

Se wolden do wesen gewert

$/ k .2 v /$ Dy polen wolden is pflegen

${ }^{95} \mathrm{Vnd}$ hatten sich ir wegen

Doch czogen sy von dannen

Mit alle eren mannen

Der meister czoch en hy(n)dennoch

In das lant czu dobryn waz ym goch

${ }^{100}$ Do vant her den konig und syn heer

\section{Laciński tekst tlumaczenia Konrada Gesselena}

in festo Exaltacionis Sancte Crucis

capitulum celebrantes.

na dzień Krzyża Świętego,

nazywany Podwyższeniem ${ }^{23}$.

${ }^{70}$ Kiedy mistrzom stało się wiadome,

że poganie do kraju

z mocą weszli

- nikt też dlatego nie [od]jechał ${ }^{24}$

pustoszyli i palili,

${ }^{75} \mathrm{gdy}^{25}$ oni rozpoznali to,

że Zakonowi

nikt nie stoi na przeszkodzie ${ }^{26}$,

Qui ut cognoverunt

paganos in tanta multitudine terram

vastantes igne etc.

mistrz Werner von Orseln

uradził tam $\mathrm{z}$ innymi,

${ }^{80}$ że on chce walczyć z Polakami.

Właśnie w tym czasie

pociągnęli z wielkim wojskiem

na króla ${ }^{27}$ i jego ludzi

przez rzekę Drwęcę,

${ }^{85}$ niczym słońce błyszczącą.

Kiedy mistrzowie przeszli rano

na drugą stronę $\mathrm{z}$ wielkim trudem

ku obozowi Litwinów,

to ci na niwach byli

${ }^{90} \mathrm{~W}$ [owym] czasie tam rozłożeni

z wojskiem ${ }^{28}$, czekając na nich.

Kiedy mistrz pożądał bitwy,

oni chcieli się tam bronić.

Polacy chcieli podjąć [bitwę]

${ }^{95}$ i podnieśli się [do walki],

ale jednak odeszli stamtąd

ze wszystkimi swoimi ludźmi.

Mistrz pociągnął za nimi

Magister Wernherus
cum aliis convenit,
quod cum Polonis belligeraret,

et transiit cum suis cum ///s. 156/// magna fatiga flumen Dribantz

prope stationem Lithwanorum;

ubi magister presumpsit bellare,

similiter et Poloni.

Sed tamen abierunt cum omnibus viris etc.

Quos magister insequitur

do ziemi dobrzyńskiej ${ }^{29}$, co było mu spieszne. in terram Dobrinensem,

${ }^{100}$ Tam znalazł on króla ${ }^{30}$ i jego wojsko ubi reperit regem cum gravi exercitu.

${ }^{23}$ Tj. 14 XI 1330

${ }^{24}$ W znaczeniu: żaden z landmistrzów nie wyjechat z Prus po odbytej kapitule generalnej. Zaproponowana przez Th. Hirschawobec niejasności narracyjnej rymowanego tekstu Wiganda - interpretacja tego fragmentu (zob. Wigand (H), s. 469, przyp. 102) nie wydaje się wtaściwa. O ile wspomnianego w Wigandowej narracji przybycia obu landmistrzów do Prus na kapitutę generalna stusznie nie wiazal on z wyprawa litewska na Prusy (zob. tez Wigand (H), s. 469, przyp. 106), o tyle trudno zgodzić się z jego opinia, że kapitutę generalna mieliby oni wraz z wielkim mistrzem odbyć w Brodnicy. Przesłanka za jej umiejscowieniem w Malborku (domu głównym Zakonu) poza uwzględnieniem zwyczajów zakonnych jest właśnie tréśc w. 73, kwestię jednoznacznie rozstrzyga zaś inny fragment (20) tacińskiego przekładu kroniki (zob. Wigand (Z/K), s. 148), gdzie mowa jest o kapitule generalnej w Malborku, którą Th. Hirsch sytuowat błędnie w 1329 r. (zob. Wigand (H), s. 466, przyp. 80). Czy kapituła generalna w 1330 r. została zwołana niezależnie od wydarzeń polityczno-militarnych, co sugeruje sam tekst Wiganda von Marburg, czy jednak była odpowiedzia na zauważane przez kierownictwo Zakonu zagrożenie militarne ze strony Giedymina $i$ Władysława I Łokietka, co przyjmowat S. Zajączkowski (zob. tenże, Polska a Zakon Krzyżacki w ostatnich latach Władysława Łokietka, Archiwum Towarzystwa Naukowego we Lwowie, Dziat 2, t. 6, z. 2, Lwów 1929, s. 158), pozostawiam tu bez rozstrzygnięcia.

25 Th. Hirsch proponowat tu lekcję 'alles' - 'wszystko' (zob. Wigand (H), s. 470, przyp. 107), jednak nie wydaje się ona właściwa.

26 W znaczeniu: wojsko zakonne ma swobode działania.

${ }^{27}$ Przy założeniu ciagłości narracji w tym niejasnym fragmencie $i$ wobec treści $w .88$, należałoby przyjmować, ̇̇e chodzi tu o wielkiego księcia Giedymina, a nie o króla Władysława I Łokietka.

${ }_{28}^{28}$ Termin 'manheit' oznaczal konkretne zbiorowisko mężczyzn, $w$ tym przypadku zbrojnych - a więc wojsko.

${ }^{29}$ Ziemia dobrzyńska (niem. Dobrinerland), obszar położony między odcinkiem środkowej Wisty oraz rzekami Drwęca i Skrwa.

${ }^{30}$ Mowa tu o Władystawie I Łokietku (ur. 3 III 1260/19 I 1261, zm. prawdopodobnie 2 III 1333), synu księcia kujawskiego Kazimierza I i księżnej opolskiej Eufrozyny, królu Polski (20 I 1320 -prawdopodobnie 2 III 1333). 


\section{Oryginal}

Mit so vreislichem gewer

Ouch waz wilhelm der grofe gros

Von vngern mit sinen genos

Do czu d(er) selben czit

$/ / s .471 / /{ }^{105}$ Begreif her alz man git

Den konig von vngern dranc

Eyn suche en do czu twanc

Daz der konig mit nichte

Kvnde gesyn bi der geschichte

${ }^{110}$ Drÿ konige offenbaren

Des ordens vyende woren

Von polen konig locut

Czu littouwe eyn heiden mut

Konig gedemyn genant

${ }^{115}$ Vnd der konig von vnger lant

Inder czit di brudere Dobrin

Hus vnd lant hatten yn

Mechteclich mit irer gewalt

Daz des koniges her manichvalt

${ }^{120}$ Hatte das hus do bestalt

Crefticlich vmme leit

Mit siner mechtigen schare breit

Ouch wurfen sy us erem her

Vintlich mit bliden ser
Laciński tekst tlumaczenia Konrada Gesselena

Similiter Wilhelmus comes

de Ungaria ibidem fuit,

ubi rex Ungarie quadam peste suppressus nequivit interesse etc.

Króla Węgier ${ }^{32}$ w opresji,

zaraza zmusiła do tego,

że król w żaden sposób

nie mógł być przy [tych] wydarzeniach.

${ }^{110}$ Zatem trzej królowie jawnie

byli wrogami Zakonu,

z Polski król Łokietek,

na Litwie pogański duch ${ }^{33}$,

król zwany Giedyminem

${ }^{115}$ i król Węgier.

$\mathrm{W}$ tym czasie bracia

zamek Dobrzyń ${ }^{34}$ trzymali

mocno w swoim posiadaniu,

[tak] że wojsko króla wielorako

${ }^{120}$ zamek ten oblegało,

silnie [go] otoczyło,

rozlegle swoimi potężnymi zastępami.

Ciskali także ze swojego wojska

blidami [pociski] bardzo wrogo
3 reges erant hostes ordinis, Lokut rex Polonie, Gedemyn Lithwanie paganus et rex Ungariae.

$\{27\}$ Eodem tempore fratres castrum Dobryn cum terra possidebant.

Quod castrum hostiliter circumdatum cum machinis impugnatur.

\section{Fragment II}

Podstawa rękopiśmienna: nieznany rkps C (tekst znany z druku: C. Schütz, Historia rerum Prussicarum, Zerbst 1592, k. 74v; odmianki: C. Schütz, Historia rerum Prussicarum, [Leipzig] 1599, k. 66r).

Treść: fragment dotyczy rezultatów bitwy pod Płowcami (ściślej II fazy tego starcia stoczonego 29 IX 1331).

\section{Oryginal}

/k. 74v/ /Wigand (H), s. 482/

Der Polen sechs hundert waren tod ${ }^{\mathrm{b}}$ zuuoren $^{\mathrm{c}}$,

\section{Laciński tekst tlumaczenia} Konrada Gesselena

///s. 184/// [...] de Polonis 600 mortui,

b Wydanie 1599: todt.

c Wydanie 1599: zuuorn.

${ }^{31}$ Chodzi tu o Vilmosa Drugetha (zm. 1342), możnego węgierskiego pochodzacego z francusko-neapolitańskiego rodu Drughet, osiadłego w okolicach Salerno, syna Jánosa I Drugheta, w 1330 r. piastującego urząd hrabiego Abaúj, Gömör i Szepes oraz urząd żupana (ispána) Borsod, Heves i Sáros.

${ }^{32}$ Chodzi o Karola I Roberta Andegaweńskiego (ur. 1288, zm. 16 VII 1342), syna króla Karola Martela Andegaweńskiego i Klemencji Habsburżanki, króla Chorwacji i Dalmacji (wiosna 1301-1 VII 1342), króla Węgier (17 XI 1308/27 VIII 1310-16 VII 1342).

${ }^{33}$ Wydaje się, że zastosowanie określenia 'muth' (w znaczeniu 'duch', 'odważny duch', 'odważna dusza') w odniesieniu do Giedymina może być śladem krażacej w Prusach $w$ drugiej $i$ trzeciej ćwierci XIV stulecia niejednoznacznej opinii o tym władcy, w której zawarta była z jednej strony jego negatywna kategoryzacja jako poganina oraz wroga Zakonu i catego kraju, z drugiej zaś trudno skrywany podziw dla jego wojennych dokonań, których skutki odczuwała bezpośrednio niemała liczba mieszkańców Prus.

${ }^{34}$ Dobrzyń (niem. Dobrin), gród położony nad środkowa Wisła, w ziemi dobrzyńskiej, ok. 27 km na zachód od Płocka.

${ }^{35}$ Chodzi tu o zbrojnych $z$ wojska Władysława I Łokietka bioracych udziat $w$ bitwie $w$ rejonie Radziejowa (określanej w historiografi jako bitwa pod Płowcami), rozegranej w dwóch fazach 27 IX 1331. 


\begin{tabular}{|c|c|c|}
\hline Oryginal & Tłumaczenie & $\begin{array}{l}\text { Laciński tekst tlumaczenia } \\
\text { Konrada Gesselena }\end{array}$ \\
\hline $\begin{array}{l}\text { One }^{d} \text { die nu sonst besondert } \\
\text { woren. }\end{array}$ & $\begin{array}{l}\text { oprócz tych, którzy ponadto byli } \\
\text { [tam polegli], }\end{array}$ & preter alios, \\
\hline $\begin{array}{l}\text { Der man nicht alle gezelen kunde }{ }^{\mathrm{f}} \\
\text { Die da tod blieben zu dieser stunde }{ }^{\mathrm{g}} \text {, } \\
{ }^{5} \text { Vnd alle wurden erschlagen, }\end{array}$ & $\begin{array}{l}\text { których nie można było wszystkich policzyć, } \\
\text { [i] którzy tam zabici zostali w tej godzinie, } \\
5 \text { i wszyscy zostali rozsieczeni, }\end{array}$ & qui numerari non poterant, \\
\hline Vnd auff dem breiten Felde lagen. & i leżeli na rozległym polu. & \\
\hline Von Breßke anderthalbe Meile, & Półtorej milii ${ }^{36}$ od Brześcia ${ }^{37}$, & in campo \\
\hline $\begin{array}{l}\text { Da war der streit zur selben weile, } \\
\text { Von den Bruedern wol gemacht, } \\
{ }^{10} \text { Mit grossen Ehren vollenbracht. }\end{array}$ & $\begin{array}{l}\text { tam bitwa w tym samym czasie } \\
\text { została przez braci dobrze wydana } \\
{ }^{10} \mathrm{i} \text { z wielką godnością dokonana. }\end{array}$ & ij miliare prope Brisik $[\ldots]$ \\
\hline
\end{tabular}

\section{Fragment III}

Podstawa rękopiśmienna: nieznany rkps C (tekst znany z druku: C. Schütz, Historia rerum Prussicarum, Zerbst 1592, k. 76r; odmianki: C. Schütz, Historia rerum Prussicarum, [Leipzig] 1599, k. 67v).

Treść: fragment dotyczy krótkiej narracji o objęciu władzy w Królestwie Polskim przez Kazimierza I Wielkiego.

\section{Oryginal}

/k. 76 r/ /Wigand (H), s. 486/

Der keine Wapen nie thet an,

Auff die Brüder vnd jhre Man ${ }^{\mathrm{h}}$ Vnd den Frieden hat gehalten, Von Koniglichen Gewalten, ${ }^{5} \mathrm{Bi}^{\mathrm{i}}$ an Meister Winrichs gezeit, Da macht jn ${ }^{\mathrm{j}}$ Gott des Lebens ${ }^{\mathrm{k}}$ qưeit, ${ }^{1}$

\section{Tłumaczenie}

który [tj. Kazimierz I Wielki] ${ }^{38}$ nie podniósł nigdy broni na braci ${ }^{39} \mathrm{i}$ ich ludzi i utrzymywał pokój królewską mocą ${ }^{5}$ aż po czasy mistrza Winricha ${ }^{40}$, kiedy Bóg zakończył jego życie.
Laciński tekst tłumaczenia Konrada Gesselena

$/ / /$ s. $190 / / /[\ldots]$ nec in vita sua arma

contra eos movit

usque ad magistrum Wynricum.

d Wydanie 1599: Ohne.

e Wydanie 1599: besonert.

f Wydanie 1599: kund.

g Wydanie 1599: stund.

h Wydanie 1599: Mann.

i Wydanie 1599: bis.

j Wydanie 1599: jhn.

k Wydanie 1599: lebens.

1 Wydanie 1599: queit.

36 Tj. ok. 11677,5 m; zob. przyp. 14.

37 Brześć (ob. Brześć Kujawski), miasto położone na Kujawach brzeskich, ok. $13 \mathrm{~km}$ na południowy zachód od Włocławka.

${ }^{38}$ Kazimierz I Wielki (ur. 30 IV 1310, zm. 5 XI 1370), syn Władysława I Łokietka i Jadwigi Bolesławówny, król Polski (25 IV 1333-5 XI 1370).

39 Wnaczeniu: braci zakonu niemieckiego.

${ }^{40}$ Chodzi tu o Winricha von Kniprode (zm. 24 VI 1382), brata rycerza zakonu niemieckiego, Nadreńczyka z urodzenia, pochodzacego z rodziny majacej dobra w Kniprath pod Monheim, w Zakonie poświadczonego w 1334 r. jako kompan wielkiego szpitalnika i komtura elblaskiego, następnie piastującego urzędy: komtura gdańskiego (\{17 III 1338\}-\{18 V1341\}), komtura bałgijskiego (\{13 I 1342-25 VI 1342\}), wielkiego marszałka i komtura królewieckiego (\{25 VII 1343\}-\{29 IX 1346\}), wielkiego komtura (\{4 X 1346\}-6 I 1352) i wreszcie 22. wielkiego mistrza (6 I 1352-24 VI 1382). 


\section{Fragment IV}

Podstawa rękopiśmienna: rekonstruowany rkps A: Monachium, Bayerische Staatsbibliothek, Cod. germ. $5249 / 24 \mathrm{~m}, \mathrm{k} .1 \mathrm{r}-1 \mathrm{v}$.

Treść: fragment dotyczy obsadzenia wzniesionego w 1337 r. zamku Bayerburg położonego nad dolnym Niemnem, a także wydarzeń, które według kronikarza zainicjować miały atak wielkiego księcia Giedymina na tę warownię wczesnym latem tegoż roku.

\begin{tabular}{lll} 
Oryginal & Tlumaczenie & Laciński tekst tlumaczenia \\
\hline
\end{tabular}

/k. $1 r /$ /SRP VI, s. 45/

Dar virczik bruder vffe wore(n)

Werhaftige herren vserkorn

Dar czu virczik schucczen

Dem huse wol czu nveczen

${ }^{5}$ Ouch der wytinge als vil

Dy tag vnd nacht ane czil

Weder dy heidenische vndit

Logen dor v(m)me czu strit

An ander gute lute

${ }^{10}$ Dy man hatte czu hute

Von natangen vnd samelant

Dy alle wern do bekant

Ouch czwene boze wicht

Dy vf dem huse sich vor pflicht

${ }^{15}$ Hatten wi se mitten andir en

Von danne(n) wolden wanderen

Vnd vorroten yo das selbege hus

Vnd worn dor v(m)me kome(n) vs

Dem konig goben insine hant

${ }^{20}$ Witinge woren sy genant

Doch der selbingen eyn

Bleip in arger meŷn
Tam $^{41}$ było 40 braci $^{42}$, wybranych zbrojnych panów, do tego 40 strzelców na dobry pożytek domu ${ }^{43}$.

${ }^{5}$ Również wielu witingów dzień i noc bez przerwy przeciwko pogańskim podstępom stało tam wokół na leżach ${ }^{44}$ do walki, nie licząc innych dobrych ludzi ${ }^{45}$, ${ }^{10}$ których miano do obrony

z Natangii ${ }^{46}$ i Sambii $^{47}$ ci wszyscy tam byli.

Także dwóch złych duchów ${ }^{48}$, którzy na zamku ${ }^{49}$ sprzysięgli się, ${ }^{15}$ że z innymi chcą stamtąd odejść i nawet zdradzić tenże dom. I w tym celu wyszli i wydali [go] w ręce króla ${ }^{50}$; ${ }^{20}$ byli [oni] nazywani witingami. Jednak jeden $\mathrm{z}$ nich pozostał w złośliwym zamiarze ///s. 204/// 40 animosos fratres

cum totidem sagittariis ordinavit ad utilitatem domus. Multos quoque wytingos

pro custodia et vigilia circumordinavit preter

Nathangos et Sambienses.

$\{62\}$ Tandem duo maligni wytingenses cum aliis descenderunt castrum volentes ipsum tradere in manus regis

de quibus unus mansit in malo proposito

${ }^{41}$ Chodzi tu o wzniesiony nad dolnym Niemnem (na wyspie) w $1337 \mathrm{r}$. zamek Bayerburg, ok. 1/4 mili (ok. 1,7 km) na zachód od Wielony. Była to pierwsza z dwóch warowni o tej nazwie zbudowanych przez zakon niemiecki w tym rejonie, która istniała do 1343 lub 1344 r. Bayerburg (II) zostat zbudowany w 1343 badź 1344 i funkcjonowat do 1384 r.

${ }^{42}$ W znaczeniu: braci rycerzy zakonu niemieckiego, którzy w kolejnym wersie określeni zostali mianem 'herren'- 'panów'.

${ }^{43}$ Lacińskie określenie 'domus'- 'dom' byto w nomenklaturze zakonu niemieckiego powszechnie stosowanym terminem opisujacym 'zamek', za to jego odpowiednikiem w języku średnio-górno-niemieckim było słowo 'hus'. Owa semantyka była rezultatem dominującej w Prusach mieszkalno-klasztornej funkcji zamków, z których większość była dla członków zakonu niemieckiego w pierwszym rzędzie ich domami zakonnymi, w tym domami konwentów; zob. S. Jóźwiak, J. Trupinda, Krzyżackie zamki komturskie w Prusach. Topografia i uktad przestrzenny na podstawie średniowiecznych źródet pisanych, Toruń 2012, s. 24-28.

${ }^{44}$ Najpewniej $w$ znaczeniu: witingowie nie mieszkali na zamku, lecz byli rozłożeni $w$ obozie lub obozach, a może nawet rozrzuceni w małych grupach w okolicy zamku dla prowadzenia działań zwiadowczych i trzymania straży (wart).

${ }^{45}$ Chodzi tu najprawdopodobniej o grupe posiadaczy ziemskich, którzy w XIV-wiecznych Prusach tworzyli bardzo heterogeniczna grupę złożona z rycerzy (pasowanych - tylko takich określano tym mianem), niepasowanych giermków oraz tzw. wolnych. Przymiotnik 'gut'- 'dobry'zostat tu zastosowany zapewne w znaczeniu 'znaczacy', 'majętny', a więc musiało chodzić raczej o rycerzy i giermków, którzy z reguly dzierżyli znaczniejsze majątki w porównaniu z wolnymi.

${ }^{46}$ Kraina (staro)pruska rozciagająca się na potudnie i południowy zachód od dolnego biegu Pregoty, w dorzeczu rzek: Huntau (niekiedy traktowana jako dolny bieg rzeki Frisching), Frisching (ob. ros. Прохладная/Prochladnaâ) i Pasmar (ob. ros. Maŭcкaя/Majskaâ).

${ }^{47}$ Kraina (staro)pruska rozciagająca się na Półwyspie Sambijskim.

48 W znaczeniu: ludzi, których umysty byty ogarnięte przez złe zamiary, zob. też w. 22.

${ }^{49}$ Chodzi tu o Bayerburg (zob. przyp. 41).

${ }^{50}$ Mowa tu o Giedyminie (zob. przyp. 9). 


\begin{tabular}{|c|c|c|}
\hline Oryginal & Tłumaczenie & $\begin{array}{l}\text { Laciński tekst tłumaczenia } \\
\text { Konrada Gesselena }\end{array}$ \\
\hline Czu beŷorn vf dem huse & na zamku Bayern ${ }^{51}$, & \multirow[t]{6}{*}{ in castro vulgariter Beyorn vel Beyeren, } \\
\hline Want sines herczen clus & ponieważ jego serce zamknięte & \\
\hline${ }^{25}$ Was vol arger boser list & ${ }^{25}$ było pełne podstępu. & \\
\hline Was des andern mete wist & Przy udziale innych & \\
\hline /SRP VI, s. 46/ Beyern das hus wolde geben & chciał wydać dom Bayern & \\
\hline In des koniges hende eben & w ręce króla właśnie & \\
\hline$[\ldots][\text { littouwen }]^{\mathrm{m}}{ }^{\mathrm{n}} \mathrm{kvnnt}$ tot $^{-\mathrm{n}}$ & {$[\ldots]$ oznajmił [Litwinom] } & quod regi tradere voluit. \\
\hline $30 \mathrm{o}-[\ldots]$ & ${ }^{30}[\ldots]$ & Idem dixit regi Lithwanorum \\
\hline$[\ldots]^{-0}$ & {$[\ldots]$} & quomodo eadem domus \\
\hline$/ k .1 v /$ Mit holcze ist gemacht quat & »z drewna jest zbudowany, [lekko] & \multirow{3}{*}{$\begin{array}{l}\text { esset lignea, minus bene compactata cum } \\
\text { argilla etc., }\end{array}$} \\
\hline Mit bosem leỷme an geslagen & słabą gliną obłożony. & \\
\hline Dy wart machstu wol dar wagen & Uczynisz tam wyprawę & \\
\hline${ }^{35}$ Vnd gewinne(n) beyern das hus & ${ }^{35}$ i zdobędziesz zamek Bayern. & quam posset faciliter vincere. \\
\hline Myn geselle der kvmpt her vs & Mój sługa wyjdzie [z zamku] & Socius quidem, ayt, meus exiet et eam \\
\hline Er an das hus eyn vuer wil lege(n) & i podłoży pod dom ogień; & succendet. \\
\hline Des hat er sich alreit irwegen & już się do tego przygotowak«. & \\
\hline $\begin{array}{l}\text { Der rede wart gewar hermans } \mathrm{w}^{\text {st }} \\
{ }^{40} \mathrm{Czu} \text { evnen bedufman svn gert }\end{array}$ & $\begin{array}{l}\text { Mowa ta dotarła do Hermanna Wsta }{ }^{52} \text {, } \\
{ }_{40} \text { pewnego prawego człowieka. }\end{array}$ & \multirow{3}{*}{$\begin{array}{l}\text { Quidam probus vir ///s. 206/// cognovit } \\
\text { huiusmodi tradimenta; }\end{array}$} \\
\hline Dem konige nuen iar & [który] królowi dziewięć lat & \\
\hline Hette gedinet das ist war & służył - to prawda. & \\
\hline Von littowen er balde quam & Przyszedł on wkrótce od Litwinów, & flens \\
\hline Vor weynen ${ }^{p}$ do er das wor nam & do Bayerburga, kiedy to [wszystko] pojął. & adiit domum \\
\hline${ }^{45}$ Vnd teten ym offen das thor & ${ }^{45}$ I otworzyli mu bramę [zamku]: & \\
\hline Ir herren ich warne vuch vorn & »Panowie, ostrzegam was, & \multirow{5}{*}{$\begin{array}{l}\text { et eos avisavit, } \\
\text { dicens de traditoribus, }\end{array}$} \\
\hline Alle syet ir vorroten & wszyscy zostaliście zdradzeni. & \\
\hline Czwene witinge das toten & Uczynili to dwaj witingowie, & \\
\hline Dy mit vuch syn vf desem hus & którzy z wami są na tym zamku & \\
\hline${ }^{50}$ Set daz sy irgen komen vs & ${ }^{50}$ Zobaczcie, że oni gdzieś poszli. & \\
\hline Der eyne ist in littower lant & Jeden jest w kraju litewskim, & \multirow[t]{4}{*}{ unum esse in castro, alium in Lithwania. } \\
\hline Vnd eyner vf desem huse bekant & drugi zaś znany na tym zamku«. & \\
\hline Dor noch indem selbin iore & Następnie w tym samym roku - & \\
\hline Tvn ich kunt vuch vor wore & oznajmiam to wam jako prawdę-- & \\
\hline${ }^{55} \mathrm{Vf}$ das fest der dry valdekeit & ${ }^{55}$ na święto Trójcy Św. ${ }^{53}$, & \multirow{8}{*}{$\begin{array}{l}\text { Eodem tempore in festo Trinitatis, } \\
\text { dum domus dicta foret perfecta, } \\
\text { rex Gedemyn } \\
\text { concepit }[\ldots]\end{array}$} \\
\hline Als das hus beyern wart bereit & kiedy dom Bayern był przygotowany, & \\
\hline Der heiden konig gedemyn & król pogan Giedymin & \\
\hline Nam czu herczen in syne(n) syn & wziął [sobie] do serca i pod swoją rozwagę & \\
\hline So offentlichen dese mere & tak jasno owe wiadomości, & \\
\hline${ }^{60}$ Dy em czu herczen ${ }^{q-}$ woren swere ${ }^{-q}$ & ${ }^{60}$ które jego sercu były ciężkie & \\
\hline $\mathrm{r}-[\ldots]$ & {$[\ldots]$} & \\
\hline$[\ldots]^{-\mathrm{r}}$ & {$[\ldots]$} & \\
\hline
\end{tabular}

\footnotetext{
m Stowo zrekonstruowane z kontekstu przez Th; zob. H. Thoma, Ein neues Bruchstück aus der Reimchronik Wigands von Marburg, ,Zeitschrift für deutsches Altertum und deutsche Literatur”, 74, 1937, s. 42.

${ }^{\mathrm{n}-\mathrm{n}}$ W wyrazach zachowane tylko górne partie liter.

${ }^{\mathrm{o}-\mathrm{o}}$ Dwa wersy ucięte.

p Th, a zanim również H i A stusznie zauważyli, że mamy tu do czynienia z błędem kopisty, który najprawdopodobniej błędna lekcję weynen niewtaściwie wyprowadził z toponimu [Beyern], zob. H. Thoma, Ein neues Bruchstück, s. 41; Wigand (H/A), s. 44. Konrad Gesselen korzystat z rkps. zawierajacego tę niepoprawna lekcję, w tym miejscu użyt bowiem imiestowu 'flens'; zob. Wigand (Z/K), s. 206.

q-q $W$ wyrazach zachowane tylko górne partie liter.

r-r Dwa wersy ucięte.

${ }_{51}$ Zob. przyp. 41.

${ }^{52}$ Osoba skądinad nieznana, przezwisko prawdopodobnie znieksztatcone.

${ }_{53}$ Tj. 15 VI 1337.
} 


\section{Fragment V}

Podstawa rękopiśmienna: rekonstruowany rkps A: Monachium, Bayerische Staatsbibliothek, Cod. germ. $5249 / 24 m$, k. 2r-2v.

Treść: fragment zawiera narracje dotyczące wyprawy wojennej wojska zakonu niemieckiego na Litwę w 1344 r., zburzenia zamku Bayerburg oraz wypadków w Estonii z 1343 r. poprzedzających tamtejszy bunt estońskich społeczności autochtonicznych.

$\begin{array}{lll}\text { Oryginał } & \text { Thumaczenie } & \text { Laciński tekst tlumaczenia } \\ & \text { Konrada Gesselena }\end{array}$

/k. $2 r / / / S R P V I, s .47 / /$

In der selbin $[\ldots]$

Czu dem dri $[. .$.

Schaden tat cz[...]

Den argen li[ttouwen] [...]

${ }^{5}$ Dy lant woren $[\ldots]$

Das gevil der [...]

Sunder eyne $\mathrm{v}[\ldots]$

Von sne und $[\text { ise }]^{\mathrm{s}}[\ldots]$

Dy das her mi[...]

${ }^{10}$ Tete riten vo[n] [dannen] ${ }^{\mathrm{t}}$

Und dy gebite[ger] [...]

Set mit dem $[\ldots]$

Vorbas ind[er] [selben] [zit] ${ }^{u}$

Als ma(n) v[ns] [vor] [wore] [git] ${ }^{\mathrm{v}}$

${ }^{15} \mathrm{Wi}$ meist(er) luter [...]

Eynen gute $[\ldots]$

Mit vorbedoch[tem] [rate ${ }^{\mathrm{w}}$

Als er wissl[...]

Dor czu mit de[m] [vollen]

${ }^{20}$ Vulbort alle[r] [gebitigeren] ${ }^{\mathrm{x}}$

Von willen de[...]

Wart beỷerb[urg] [...]

So balde in ey[ner] [wile]

Neder wend[ig] [eine] [mile] ${ }^{\mathrm{z}}$

${ }^{25}$ Wart eyn and[er] [...]

Von dem me[ister] [...]

Wol gebuwet $[\ldots]$

Di bruder de[...] [...]

$\mathrm{S}[\ldots]$
W tych samych [...]

$\mathrm{w}[\ldots]$

uczynił szkody $[\ldots]$

złośliwym Litwinom [...]

${ }^{5}$ ziemie były $[\ldots]$

zasobne $[\ldots]$

Jednak $[\ldots]$

śniegu i $[$ lodu $][\ldots]$

które wojsko [...]

${ }^{10}$ ruszyło [stamtąd]

i dostojnicy $[\ldots]$

$\mathrm{z}[\ldots]$

Następnie w [tymże czasie],

jak [nam podawane jest jako prawda],

${ }^{15}$ jak to mistrz $\operatorname{Luter}^{54}[\ldots]$

[...]

z przemyślną [radą]

gdy on $[. .$.

ponadto za [pełną]

${ }^{20}$ zgodą [wszystkich dostojników]

$\mathrm{z}$ woli $[\ldots]$

został Bayerburg ${ }^{55}[\ldots]$

bezzwłocznie w [krótkim czasie]

[o jedną milę] poniżej

${ }^{25}$ został inny ${ }^{56}[\ldots]$

przez [wielkiego] mistrza $[\ldots]$

dobrze zbudowany [...]

Bracia [...]

[...] ///s. 214/// [...] quam devastat duobus diebus

et in multis dampnificat;

terra enim habundans fuit.

Sed propter inundacionem

ex resolucione nivis et glaciei dissolute ortam compulsus est exire.

$\{71\}$ Ceterum in eodem tempore

magister Luterus

cum accessu suorum preceptorum

maturo consilio

castrum Beyerborg vulgariter dictum exustum et continuo ad 1 miliare inferius aliud erectum,

s Uzupetnienie zaproponowane przez Th oraz H i A; zob. H. Thoma, Ein neues Bruchstück, s. 43; Wigand (H/A), s. 47.

${ }^{t}$ Uzupetnienia zaproponowane przez Th oraz H i A; zob. H. Thoma, Ein neues Bruchstück, s. 43; Wigand (H/A), s. 47.

"Uzupetnienia zaproponowane przez Th oraz H i A; zob. H. Thoma, Ein neues Bruchstück, s. 43; Wigand (H/A), s. 47.

v Uzupetnienia zaproponowane przez Th oraz H i A; zob. H. Thoma, Ein neues Bruchstück, s. 43; Wigand (H/A), s. 47.

w Uzupetnienia zaproponowane przez Th oraz H i A; zob. H. Thoma, Ein neues Bruchstück, s. 44; Wigand (H/A), s. 47.

${ }^{x}$ Uzupetnienia zaproponowane przez Th oraz H i A; zob. H. Thoma, Ein neues Bruchstück, s. 44; Wigand (H/A), s. 47.

y Uzupetnienia zaproponowane przez Th oraz H i A; zob. H. Thoma, Ein neues Bruchstück, s. 44; Wigand (H/A), s. 47.

z Uzupetnienia zaproponowane przez Th oraz H i A; zob. H. Thoma, Ein neues Bruchstück, s. 44; Wigand (H/A), s. 47.

${ }^{54}$ Mowa tu o Ludolfie (Lutherze) Königu (ur. 1280/1290, zm. 1347 lub 1348), bracie rycerzu zakonu niemieckiego, pochodzacym z saskiego rodu ministeriałów osiadlego we władztwie kapituty halberstadzkiej, majacego dobra we wsi Watzum, poświadczonym w Zakonie na urzędach: komtura domowego królewieckiego (1328), skarbnika Zakonu (\{17 II 1332\}-\{17 III 1338\}), wielkiego komtura (\{6 V 1338\}-6 I 1342), 20. wielkiego mistrza (6 I 1342-13 IX 1345), a po złożeniu z tego urzędu piastujacym urząd komtura engelsburskiego ([XII] 1345-\{5 VI 1347\}).

${ }_{55}$ Chodzi tu o zamek Bayerburg (I) (zob. przyp. 41).

${ }^{56}$ Mowa tu o drugim zamku o nazwie Bayerburg (zob. przyp. 41). 


\begin{tabular}{|c|c|c|}
\hline Oryginal & Tłumaczenie & $\begin{array}{l}\text { Laciński tekst thumaczenia } \\
\text { Konrada Gesselena }\end{array}$ \\
\hline 30 aa- $[\ldots]$ & ${ }^{30}[\ldots]$ & \\
\hline$[\ldots]^{\text {-aa }}$ & {$[\ldots]$} & \\
\hline /k. $2 v / / / S R P$ VI, s. $48 / /[\ldots]$ vor brente & {$[\ldots]$ spalono } & \\
\hline$[\ldots] \mathrm{r}$ also nente & {$[\ldots]$ również nazwano, } & \\
\hline$[\ldots] \mathrm{s}$ bouwete & [...] zbudowano, & \\
\hline $35[\ldots]$ nvwete & ${ }^{35}[\ldots]$ na nowo & \\
\hline$[\ldots]$ te & {$[\ldots]$} & \\
\hline$[\ldots]$ ete & {$[\ldots]$} & \\
\hline$[\ldots]$ orden alsam & [...] Zakon podobnie & quod eodem vocabulo Beyersburg \\
\hline$[\ldots][$ bey]ern de(n) nam & {$[\ldots]$ nazwę Bayerburg ${ }^{57}$} & s(cilicet), est vocatum, sytu duntaxat \\
\hline $40[\ldots]$ arn & ${ }^{40}[\ldots]$ & $/ / / s .216 / / /$ variato. Nam et Hinricus dux \\
\hline$[\ldots] \mathrm{rt}$ warn & {$[\ldots]$} & Bavarie petiit, ut tali vocabulo \\
\hline$[\ldots]$ dy czal & {$[\ldots][\mathrm{w}]$ liczbie } & denominaretur, s(cilicet) Beyeren, quod \\
\hline$[\ldots]$ obir al & {$[\ldots]$ wokoło } & factum est. \\
\hline$[\mathrm{Zu}][$ meister $][\text { luters }]^{\mathrm{bb}}$ geczit & [w] czasie [urzędowania mistrza Ludolfa], & $\{72\}[\ldots]$. Anno 1343 tempore magistri \\
\hline${ }^{45}$ [Als] [man] [uns] [vor] [war] e ${ }^{c c}$ gýt & ${ }^{45}$ [jak nam] podawane [jest jako prawda], & Luteri, \\
\hline [Der] [konig] [von] [de]nnemarkte ${ }^{\mathrm{dd}}$ was & [król] Danii ${ }^{58}$ był & dum rex Dacie adhuc dominaretur \\
\hline [In] [dem] [lande] [czu] $]^{\mathrm{ee}}[\mathrm{r}] \mathrm{evel}$ als ich las & [w ziemi] rewalskiej ${ }^{59}-$ jak przeczytałem $^{60}$ & in terra Reveliensi etc., \\
\hline$[\ldots] \mathrm{n}$ & {$[\ldots]$} & \\
\hline$[\ldots][\mathrm{cz}] \mathrm{u}$ vorn & {$[\ldots]$ przedtem } & \\
\hline${ }^{50}$ [Ritter] [und] [koniges] [knecht] $\mathrm{e}^{\mathrm{ff}}$ & ${ }_{50}^{5}$ [Rycerze i giermkowie króla] & milites et clientes regis tantis \\
\hline [Von] [erberem] [ges]lechte ${ }^{g g}$ & [Z czcigodnych rodów] & oneribus et fatigis incolas opprimebant \\
\hline$[\ldots][\mathrm{o}] \mathrm{r}$ & {$[\ldots]$} & quod in gemitu et dolore nimio magistro \\
\hline$[\ldots] \mathrm{rn}$ & {$[\ldots]$} & et fratribus querulabantur, signanter illi, \\
\hline$[\ldots] \mathrm{r}$ & {$[\ldots]$} & qui vulgariter dicuntur Ystenses, \\
\hline $55[\ldots]$ stur & $55[\ldots]$ & Osalyenses et ceteri vulgares. \\
\hline$[\ldots]$ elhaft & {$[\ldots]$} & Tanta quoque \\
\hline$[\ldots]$ ben craft & {$[\ldots]$ siłą } & fuit eorum violencia, $[\ldots]$ \\
\hline [...] un(d) h(er)czen & {$[\ldots]$ i serca } & \\
\hline$[\ldots]^{\text {hh-}}[$ un $] \mathrm{d}$ smerczen ${ }^{\text {-hh }}$ & [...] [i] ból & \\
\hline 60 ii $[\ldots]$ & ${ }^{60}[\ldots]$ & \\
\hline$[\ldots]$ & {$[\ldots]$} & \\
\hline$[\ldots]^{-\mathrm{ii}}$ & {$[\ldots]$} & \\
\hline
\end{tabular}

aa-aa Dwa wersy ucięte.

bb Uzupetnienia zaproponowane przez Th oraz H i A; zob. H. Thoma, Ein neues Bruchstück, s. 44; Wigand (H/A), s. 48.

cc Uzupetnienia zaproponowane przez Th oraz H i A; zob. H. Thoma, Ein neues Bruchstück, s. 44; Wigand (H/A), s. 48.

dd Uzupetnienia zaproponowane przez Th oraz H i A; zob. H. Thoma, Ein neues Bruchstück, s. 44; Wigand (H/A), s. 48 .

ee Uzupetnienia zaproponowane przez Th oraz H i A; zob. H. Thoma, Ein neues Bruchstück, s. 44; Wigand (H/A), s. 48 .

ff Uzupetnienia zaproponowane przez Th oraz H i A; zob. H. Thoma, Ein neues Bruchstück, s. 44; Wigand (H/A), s. 48.

gg Uzupetnienia zaproponowane przez Th oraz H i A; zob. H. Thoma, Ein neues Bruchstück, s. 44; Wigand (H/A), s. 48.

hh-hh $W$ wyrazach zachowane tylko górne partie liter.

ii-ii Trzy wersy ucięte.

57 Zob. przyp. 56.

${ }^{58}$ Chodzi tu o Waldemara IV Atterdaga (ur. ok. 1321, zm. 24 X 1375), pochodzacego z rodu Estrydsenidów syna króla Danii Krzysztofa II i księżnej pomorsko-wołogoskiej Eufemii, króla Danii (24 VI 1340-24 X 1375).

${ }^{59}$ Rewal (niem. Rewel, ob. est. Tallinn), zamek i miasto położone w Harii, nad Zatoka Fińska.

${ }^{60}$ Th. Hirsch stusznie przypuszczat, że Wigand von Marburg, konstruując narracje o wydarzeniach $w$ Inflantach $i$ Estonii w 1343-1344, korzystat poza kronika Hermanna von Wartberge i kronika oliwska w redakcji opata Stanistawa z zaginionej, a znacznie szerszej pisemnej relacji wyszłej spod ręki kogoś z Prus (zob. Wigand (H), s. 501, przyp. 329; ponadto SRP, t. 2, s. 70, przyp. 5), kto byt w Inflantach i w Estonii wraz z wojskiem posiłkowym wystanym tam z Prus wczesna jesienia 1343 r.; zob. S. Jóźwiak, Wyprawa armii krzyżackiej z Prus do Estonii w latach 1343-1344, „,Komunikaty Mazursko-Warmińskie”, 238, 2002, $n r$ 4, s. 495-500 (tu starsza literatura). 


\section{Fragment VI}

Podstawa rękopiśmienna: rekonstruowany rkps A: Karlsruhe, Badische Landesbibliothek, Cod. Donaueschingen A III 9, Fragm. A, k. 1r-1v.

Treść: fragment zawiera narracje dotyczące wydarzeń z 1345 r.: dwóch wypraw zakonnych na Żmudź, wyprawy wojsk księcia Kiejstuta i wielkiego księcia Olgierda na Prusy oraz budowy zamku Johannisburg (ob. pol. Pisz).

\section{Oryginal}

/k. $1 r / / / S R P I V$, s. 2//

Den brudern gelucke wart bekant

Das bruder heynrich dusemer

jj Prusen landes homeister

Des ordens dutschen huses

${ }^{5} \mathrm{I}(\mathrm{e}) \mathrm{r}$ (usa)1(e)m des spitalis

In der czít eyn reyse wart

Czu hant nicht lange gespart

Vor líttower lant

Vf des velt augken genant

${ }^{10}$ Man do selbes weder kart

Czu hant wart eyn and[er] vart

Dy man dor noch tet als ee

Vf dem velde germedie

Dy reyslute wedir karten

${ }^{15}$ Want sy des woren warten

Das der reysen keyne

Den dy czwu alleyne

Des winters mochten geschen

$\mathrm{Nu}$ moget ir wundir hy spen

${ }^{20}$ Do vor loufen worn gar

Tusent vnd dry்hundirt iar

Vumf vnd virzik daruf dy் czal

Was unsers herren obir al

An dem dvnnerstage czu mítage

als ma(n) gyt

${ }^{25}$ Der gemeynte(n) wochen inder czỳt

//SRP IV, s. 3// So man dy selen al begat

Jerlich mit gebete bestat

Czu der czit als man seide

Der heyden konige beide

\section{Laciński tekst tlumaczenia} Konrada Gesselena

Tlumaczenie

braciom $^{61}$ odpowiednio uczyniono

wiadomość,

że brat Heinrich Dusemer ${ }^{62}$

[został] mistrzem kraju pruskiego

zakonu domu niemieckiego

${ }^{5}$ szpitala jerozolimskiego.

W tym czasie rejza

akurat nie na długo się zatrzymała

przed krajem Litwinów ${ }^{63}$

na polu zwanym Augken ${ }^{64}$.

${ }^{10}$ Kiedy z niej powrócono,

od razu była inna wyprawa,

którą po tym uczyniono, jak wcześniej ${ }^{65}$,

na pole Germedie ${ }^{66}$.

Rejzownicy powrócili,

${ }^{15}$ bowiem oni przestrzegali tego,

aby żadna inna rejza,

aniżeli tylko dwie

nie mogły się odbyć w zimie.

Teraz nie powinniście się dziwić.

${ }^{20}$ Wówczas to mijał

rok tysiąc trzysta

czterdziesty piąty, liczony

był naszego Pana w ogólności,

w czwartek w południe, jak się podaje, feria 5 ta

${ }^{25} \mathrm{~W}$ czasie tygodnia,

kiedy sprawuje się za dusze

coroczne modlitwy ${ }^{67}$,

w tym czasie, gdy widziano

obu królów pogan,
$/ / / s .234 / / /[\ldots]$ et notum factum est fratribus ibidem eciam de magistro generali Hinrico.

Post hec in brevi statuunt reysam

in Lithwaniam

in campum Augken,

sed revertuntur.

Et cito statuunt aliam in

campum Germedie

et eciam revertuntur.

Nec plures consueverunt

in hyemes servare reysas,

quam 2.

\{86\} Anno 1345

in ebdomada

animarum

ij H proponowat wstawienie w tym miejscu stowa 'wart', tylko wówczas bowiem cały fragment stałby się zrozumiaty; zob. Wigand (H:ZF), s. 2, przyp. a. Tekst łacińskiego przekładu Konrada Gesselena uprawdopodabnia tę propozycję; zob. Wigand (Z/K), s. 234.

${ }^{61}$ Mowa o braciach inflanckiej gatęzi zakonu niemieckiego, na co wskazuje łacińskie tlumaczenie; zob. Wigand (Z/K), s. 234.

${ }^{62}$ Heinrich Dusemer (ur. ok. 1295, zm. 1353), brat rycerz zakonu niemieckiego, prawdopodobnie pochodzacy z Frankonii, w 1325/1326 r. poświadczony jako kompan wójta biskupa sambijskiego, później petniący urzędy: prokuratora tapiawskiego (1328), komtura ragneckiego (\{23 III 1329\}-?), wójta sambijskiego (1333/1334), komtura brandenburskiego (\{1 XII 1334\}-\{25 III 1335\}), komtura królewieckiego i wielkiego marszałka (\{VIII 1335\}-\{6 XII 1339\}), komtura brodnickiego (\{21 XII 1339\}-1343/1345), petniacego obowiazki wielkiego mistrza (14 IX-13 lub 18 XII 1345), 21. wielkiego mistrza (13 lub 18 XII 1345-1351/1352), a po złożeniu z tego urzędu wójt bratiański (1351/1352-1353).

63 W znaczeniu: trwająca krótko wyprawa nie dotarła do samej Litwy.

${ }^{64}$ Augken (Aukeyn), lauks położony na Żmudzi, identyfikowany z okolica wspótczesnej miejscowości Akstinai, położonej ok. $35 \mathrm{~km}$ na pótnocny zachód od wspótczesnego Jurbarkas (pol. Jurbork).

${ }^{65}$ W znaczeniu: jak poprzednia wyprawę.

${ }^{66}$ Germedie, lauks/rejon niezlokalizowany.

${ }^{67}$ Chodzi o czwartek $w$ tygodniu, w którym przypadal dzień zaduszny roku 1345, tj. 3 XI 1345. 


\section{Oryginal}

${ }^{30}$ Algart dorczu kẏnstut

Dy் konige obil gemut

Czu rastenburg quome(n) ỳn gerant

Gar menlich ir kant

Mit geczoulicher hant getat

$/ k .1 v /{ }^{35}$ Quomen sy in dy stat

Do sy vingen und slugen

Was yn was czu vugen

Wol vumf vnd virtzik gut(er) man

Vor dy stat vf eẏnen plan

${ }^{40}$ Se dy balde leten

Dy heyden mit ẏn beyten

Doselbest vf dy stunde

Dy man vordy hvnde

Se hyben vnd slugen

${ }^{45}$ Mit vil vngevuegen

Dy stat vorherten vn(d) brante(n)

Ouch gevangen von danne(n) sante(n)

Wip kynt vnd dy man

Vurten sy von dan

${ }^{50}$ Das heren von mittage

Durte inder lage

Hyn abe indy nacht

Dy konige mit aller macht

Wedir iageten czu lande

${ }^{55}$ Inder czit das irkande

Bruder heynrich dusemer

Der do was homeister

Sont johans burg daz hus

Tet er buwen czu genus

${ }^{60}$ Vf das vlys de pysse

Dy rede sint gewisse

Dor noch in dem andern iore

Als man vns saget vor wore

Do tusent vnd drÿhundirt

${ }^{65}$ Inden czỳten besundert

Dy czal vnsers herren was

Seben vnd virczyk als ich las

\section{Laciński tekst tłumaczenia} Konrada Gesselena

Thumaczenie

${ }^{30}$ Olgierda $^{68}$ i do tego Kiejstuta ${ }^{69}$, owi królowie ze złym nastawieniem przybyli, wpadając do Rastenburga ${ }^{70}$ całkiem po męsku, niszczącą ręką działając.

${ }^{35}$ Przybyli do miasta ${ }^{71}$, gdzie chwytali i zabijali, co im się nawinęło, dobrze 45 dobrych ludzi na równinę przed miasto ${ }^{40}$ wkrótce popędzili.

Poganie przeto czynili gwałty ${ }^{72}$ tam w tym czasie, niczym psy przebijali i zabijali ${ }^{73}$

${ }^{45} \mathrm{Z}$ wielką gwałtownością. Miasto spustoszyli i spalili, jak również wysłali stamtąd jeńców, kobiety, dzieci i mężczyzn, uprowadzili stamtąd ${ }^{74}$.

${ }^{50}$ Pustoszenie od południa

trwało

aż do nocy.

Królowie z całą mocą znowu zaatakowali okolicę ${ }^{75}$.

${ }^{55}$ Wówczas dowiedział się o tym brat Heinrich Dusemer, który był wielkim mistrzem, zamek św. Jana ${ }^{76}$ nakazał zbudować na pożytek

${ }^{60}$ nad rzeką Pisą ${ }^{77}$, opowieści [o tym] są pewne.

Potem w innym roku, jak nam to powiedziano jako prawdę, tysiąc trzysta,

${ }^{65}[\mathrm{a}]$ konkretnie w czasach, [kiedy] wedle rachuby naszego Pana był [rok] czterdziesty siódmy - jak przeczytałem ${ }^{78}$
Algard et Kynstud

ambo reges

veniunt potenti manu, intrant opidum Rastenburg,

in quo capiunt et occidunt etc.,

45 eciam bonos viros

extra portas frustatim diviserunt,

opidum succendunt,

viros, mulieres et pueros deducunt captivos.

Hec vastacio duravit a meridie

in noctem,

in qua reges

festinant ad patriam.

\{87\} Unde ad profectum patrie

frater H(inricus) Dusmer magister

fecit edificare castrum Johannis

supra flumen Pisse.

///s. 236/// $\{88\}$ Deinde anno 1347 [...]

68 Olgierd (lit. Algirdas) (ur. ok. 1296 lub ok. 1304, zm. 24 V 1377), syn Giedymina, brat Kiejstuta, wielki książe Litwy (1345-1377).

${ }^{69}$ Kiejstut (lit. Kęstutis) (ur. ok. 1308/1310, zm. 15 VIII 1382), syn Giedymina, brat Olgierda, książę trocki (1345-1381), wielki ksiązę Litwy (1381-1382).

${ }^{70}$ Rastenburg (stpol. Rastembork, ob. pol. Kętrzyn), w 1345 r. osada miejska (aczkolwiek najprawdopodobniej bez nadanych praw miejskich) $i$ zamek zakonu niemieckiego położony w Prusach Dolnych.

${ }_{71}$ Zapewne anachronizm Wiganda von Marburg (zob. przyp. 70). Rastenburg uzyskat prawa miejskie $w 1357 r$.

72 W znaczeniu: dokonywali różnorodnych aktów przemocy, nie tylko naruszania integralności cielesnej swoich ofiar.

73 W znaczeniu: mieszkańców Rastenburga wypędzonych przed osadę.

74 Stylistyczne powtórzenie treści zawartej w w. 47, w znaczeniu: pochwycili jeńców, których odestali (zapewne pod straża) na Litwę.

75 W znaczeniu: po spustoszeniu Rastenburga ponownie rozeszli się ze swoimi zbrojnymi po okolicy.

76 Johannisburg (stpol. Jońsbork, ob. pol. Pisz), zamek zakonu niemieckiego położony w Prusach Dolnych, ok. $43 \mathrm{~km}$ na południowy wschód od współczesnego Mragowa.

${ }_{77}$ Pisa (niem. Pissa), rzeka będąca prawym doptywem środkowej Narwi.

78 Utrwalona pisemnie narracja dotyczaca wyprawy litewskiej na Prusy w lutym/[marcu?] 1347 r., z której korzystat Wigand von Marburg, pozostaje nieznana. W każdym razie opis/wyciag C. Schütza (zob. tenże, Historia rerum Prussicarum, Zerbst 1592, k. 81v) wskazuje, że opis tych wydarzeń w kronice Marburczyka byt rozbudowany; zob. też Wigand (H), s. 508, przyp. 395. 


\section{Fragment VII}

Podstawa rękopiśmienna: rekonstruowany rkps A: Karlsruhe, Badische Landesbibliothek, Cod. Donaueschingen A III 9, Fragm. A, k. 2r-2v; rekonstruowany rkps B: Karlsruhe, Badische Landesbibliothek, Cod. Donaueschingen A III 10, k. 1r, 1v.

Treść: fragment zawiera narrację dotyczącą wyniku bitwy nad rzeką Strawą (Strebą) 2 II 1348 oraz związanych z nią dwóch fundacji klasztornych w Prusach.

\section{Oryginal}

/B: k. $1 \mathrm{r}-\mathrm{-} / / / \mathrm{SRP} I V$, s. 4// //SRP II,

s. 512, Fragm. IV--//

${ }^{1}$ Unser vrauwen bilde

Dy in der zcit garmilde

Vor den augen hyn unde her

Was den cristen eyn gut wer

${ }^{5}$ Dar zcu ir gnade mit volleist

Unde ir hulfe allir meist

Ist von marien kome(n)

/A: $k$. $2 r /$ Den cristen do ${ }^{\mathrm{kk}-\mathrm{czu}}$ vromen-kk

Merclichen das ${ }^{11}$-eys $\mathrm{czu}^{-11}$ brach

${ }^{10}[\mathrm{~V}] \mathrm{f}$ dem vlise gevroren swach

Dorynne $^{\mathrm{mm}}$ dy heiden irtruncken ${ }^{\mathrm{nn}}$

Von wasser do ${ }^{\text {oo- }}$ vor sunken ${ }^{-o o}$

Dyp cristen dar obir al

qq-Gyngen an ${ }^{-q q}$ musal

${ }^{15} \mathrm{Vnd}^{\text {rr }}$ obir dy toden

Do $^{\text {ss }}$ se ${ }^{\text {tt-ir slagen woden }}{ }^{\text {tt }}$

Mit trucken ${ }^{\text {ul-vusen obir vurten }}{ }^{\text {-uu }} /--B$ :

k. $1 r / / /-$ SRP II, s. 512, Fragm. IV//

Keynen schaden ny gesparten

Sust nam der strit eyn ende

${ }^{20}$ Des uns got von sunden wende
Wizerunek naszej Pani, który wówczas tak słodko przed oczami tu i tam ${ }^{79}$ był dla chrześcijan dobrą obroną

${ }^{5}$ Do tego jej łaska pełnym strumieniem ${ }^{80}$ i jej największa pomoc przyszła od Maryi na korzyść chrześcijan ${ }^{81}$, [kiedy] lód naocznie pękł

${ }^{10}$ słabo zamarznięty na rzece ${ }^{82}$, gdzie poganie się potopili pochłonięci przez wodę, [zaś] chrześcijanie wszędzie bez trudności przeszli ${ }^{15}$ i ponad zabitymi których oni rozsiekli ${ }^{83}$ suchą stopą się przeprawili, nie ponosząc żadnych szkód; i tak bitwa się zakończyła,

${ }^{20}$ czym Bóg zachował nas ${ }^{84}$ od grzechu.

\section{Laciński tekst tlumaczenia Konrada Gesselena}

///s. 244/// [...] virgini Mariae, cuius ymago in vexillo hospitum eleganter depicta erat,

de cuius

intervencione venit victoria ista.

$\{95\}$ Notanter accidit, quod christiani illesi pertransierunt glaciem fragilem

et sicco pede super occisis et submersis;

et sic terminatum est hoc bellum Lithwania iuxta flumen Streben.

kk-kk $B$ : zcu vrome(n).

11-11 $B$ : yes zcu.

mm $B$ : Do ynne.

nn $B$ : irtruncke(n).

oo-oo $B$ : vorsunken.

pp $B$ : De

qq-qq $B$ : Gingen ene.

rr $B$ : Vnde.

ss $B:$ De

tt-tt $B$ : irslagen hoden.

uu-uu $B$ : vusen obirvurte(n).

${ }^{79}$ Niewatpliwie chodzi tu o nachoragiewny wizerunek NMP widniejacy na jednym ze znaków bojowych wojska krzyżowego w bitwie nad rzeka Strawa (Streba) 2 II 1348.

${ }^{80}$ Th. Hirsch proponowat tu znaczenie 'Unterstützung' - 'wsparcie' (zob. Wigand (H), s. 512, przyp. 422), ale nie wydaje sie to najwłaściwszym rozwiąaniem.

${ }^{81}$ Chodzi tu o wojsko krzyżowe pod wodza dostojników zakonu niemieckiego.

${ }^{82}$ Mowa tu o rzece Strawa (niem. Strebe, ob. lit. Strèva), która jest prawym doptywem środkowego Niemna.

${ }^{83}$ W tym wersie lekcje z rkps. B wydaja się poprawniejsze, stąd thumaczenie oparto na nich. Sugestie Th. Hirscha byty niewtaściwe; zob. Wigand (H:ZF), s. 4, przyp. 1.

${ }^{84}$ Albo Wigand von Marburg wyraża tu bezpośrednio swoja identyfikację z krzyżowcami, albo jest to ślad bezpośredniego zapożyczenia z nieznanej relacji naocznego świadka bitwy nad Strawa. 


\begin{tabular}{|c|c|c|}
\hline Oryginal & Tłumaczenie & $\begin{array}{l}\text { Laciński tekst tłumaczenia } \\
\text { Konrada Gesselena }\end{array}$ \\
\hline Dor noch inder selbin czit & Po tym w tym samym czasie, & $\{96\}$ Dicta victoria \\
\hline Do gewest was der stryt & kiedy była bitwa & \\
\hline Czu littowen uf der streben & na Litwie nad Strawą - & \\
\hline Nv merket hy gar eben & zauważcie to więc teraz - & \\
\hline${ }^{25}$ Durch dy segehaftykeit & ${ }^{25}$ przez błogosławieństwo, & ex speciali gratia indulta \\
\hline Dy got do der cristenheit & którego Bóg chrześcijaństwu & est christianis, \\
\hline \multicolumn{3}{|l|}{ /B: k. 1v--/ //SRP II, s. 512-513, } \\
\hline Fragm. V--// Hat von gnoden gegeben & z łaski udzielił & \\
\hline${ }^{\mathrm{vv}-I n d e m}$ strite $\mathrm{vf}^{-\mathrm{vv}}$ der streben ${ }^{\mathrm{ww}}$ & w bitwie nad Strawą, & \\
\hline $\mathrm{Vm}^{\mathrm{xx}}$ das der meister Dusemer ${ }^{\mathrm{yy}}$ & [z uwagi na to właśnie] mistrz Dusemer ${ }^{85}$ & quum magister Dusemer \\
\hline${ }^{30}$ Und $^{\mathrm{zz}}$ dar $\mathrm{czu}^{\mathrm{aaa}}$ alle gebiteger ${ }^{\mathrm{bbb}}$ & ${ }^{30} \mathrm{i}$ do tego wszyscy dostojnicy & cum preceptoribus \\
\hline Wurden mit rate in ${ }^{c c c}$ eyn & byli w radzie jednomyślni, & voverat \\
\hline Wy sydd marien der reyn & że dla Maryi czystej & reddere Deo laudes et claustrum edificare, \\
\hline $\mathrm{Czu}^{\text {eee }}$ lobe ${ }^{\mathrm{fff}-} \mathrm{vnd} \mathrm{czu}^{\text {-fff }}$ eren ton & na chwałę i dla czci & \\
\hline Eyn lobelich ${ }^{\text {ggg }}$ dinst machten ${ }^{\text {hhh }}$ schon & uczynią zaraz chwalebną służbę ${ }^{86}$. & \\
\hline${ }^{35}$ Ouch meister dusemer inder czit ${ }^{\mathrm{iii}}$ & ${ }^{35}$ Wówczas również mistrz Dusemer, & \\
\hline Von ${ }^{\mathrm{jj} j}$-danvelt brudir syfryt $\mathrm{t}^{\mathrm{ijj}}$ & brat Siegfried von Dahenfeld ${ }^{87}$ & \\
\hline Mit kkk-allir gebiteger-kkk vulbort & za zgodą wszystkich dostojników & \\
\hline Eyn juncvrowen ${ }^{111}$ closter so vort & natychmiast klasztor dziewic ${ }^{88}$ & ut factum est in Konigsberg, \\
\hline mmm-Machte(n) czu konisberg inder ${ }^{-m m m}$ stat & uczynili w mieście Królewcu ${ }^{89}$, & ubi construxerunt claustrum virginum, \\
\hline${ }^{40}[\mathrm{~V}] \mathrm{nd}^{\mathrm{nnn}}$ haben das alsampt besat & ${ }^{40} \mathrm{i}$ tak opatrzyli & redditibus ditantes juxta perstintem, \\
\hline
\end{tabular}

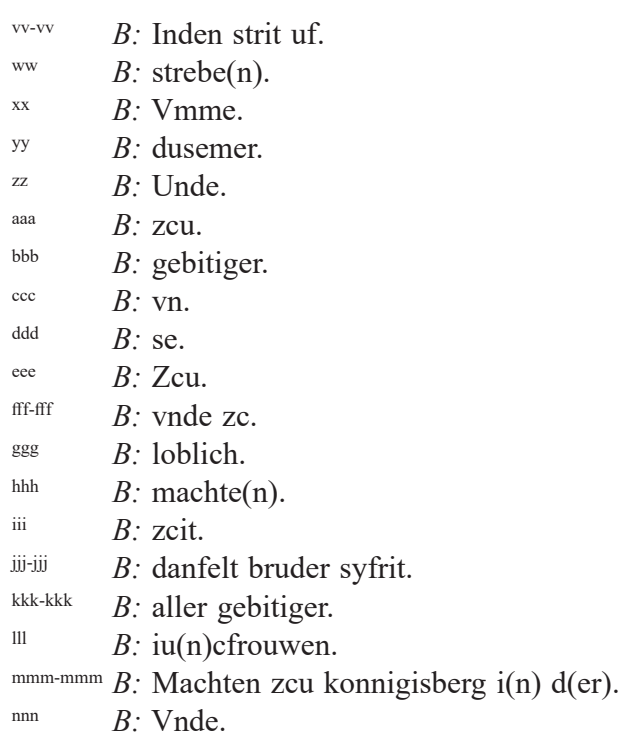

85 Zob. przyp. 62.

${ }^{86}$ W znaczeniu: ufunduja miejsce do stużby bożej, tj. kultu i postugi chrześcijańskiej.

87 Siegfried von Dahenfeld (zm. 12 III 1360), brat rycerz zakonu niemieckiego, piastujący urzędy: komtura ragneckiego (\{19 VI 1342\}-\{2 VI 1344\}), komtura bałgijskiego (\{26 VII 1346\}-\{21 IX 1346\}) i wreszcie wielkiego marszałka i komtura królewieckiego (\{4 X 1346\}-12 III 1360).

${ }^{88}$ Mowa tu o klasztorze benedyktynek (później benedyktynek-cysterek) położonym w Lipniku (niem. Löbenicht), jednym z trzech miast królewieckich (zob. przyp. 89), aczkolwiek niepodlegającym jurysdykcji tamtejszej rady miejskiej, lecz zakonu niemieckiego, ufundowanym 17 XI 1349.

${ }^{89}$ Królewiec (niem. Königsberg, ob. ros. Калининград/Kaliningrad), zamek i zespót miejski Stare Miasto Królewiec (niem. Altstadt Königsberg), Lipnik (niem. Löbenicht) i Knipawa (niem. Kneiphof) wraz z przedmieściami, położone w Prusach Dolnych, nad dolna Pregoła, stolica diecezji sambijskiej. Określenie kronikarza jedynie ogólnikowo odnosi się do całego królewieckiego zespolu osadniczego (zob. przyp. 88). 


\section{Oryginal}

/A: k. 2v/ Ouch indem closter rente //SRP IV, s. $5 / / \mathrm{Czu}^{\circ 00}$

eynem wissem presente

Gemacht vnd ${ }^{\text {ppp }}$ gegeben $/--B$ :

k. 1v/ //--SRP II, s. 512-513, Fragm. V//

Dy wile das sy leben

${ }^{45}$ Mit gebuede wol an gericht

Dor ynne wonen czu guter pflicht

Indem closter ist sogethan wesen

Das dy iu(n)cvrowe(n) singen und lesen

Ouch halden do dy tage czit

${ }^{50} \mathrm{In}$ ere als is ist geseyt

Vnd dyne(n) gote von allir macht

Do selbist beyde tage vnd nacht

Nach sinte bernhardes orden

Des swestern sy sint wurden

${ }^{55}$ Noch des heiligen vaters lere

Halden se den orden here

Do von sy ouch nicht wanken

In allen eren gedanken

Dor vf seczczen se ewiclich

${ }^{60}$ Gote dinen steticlich

Do das closter yn der czyt

Was bereyt als man gýt

Ouch indem andern iore

Als man sagit vor wore

${ }^{65}$ Meister dusemer bẏ siner czít

Als got der herre do ryt

Bruder heynrich dusemer

Meister vnd dy gebyteger

Von der gotis gnade

${ }^{70}$ Vnd mit syme rade

Stifte eyn closter czu welow

Gote czu lobe vnd schow

Von dem orden der my(n)ner bruder

Gote vnd syner liben muder
Tłumaczenie

Laciński tekst tlumaczenia Konrada Gesselena

klasztor również w uposażenie,

jako pewny podarunek

[to] uczynili i nadali,

dopóki będą żyć,

${ }^{45} \mathrm{~W}$ zabudowania dobrze wyposażony,

aby tam żyć na dobrą służbęę

Tak został uczyniony klasztor,

aby dziewice śpiewały i czytały,

i odmawiały godziny kanoniczne

${ }^{50} \mathrm{~W}$ czci, jak to zostało powiedziane,

i służyły Bogu ze wszystkich sił

tamże dniem i nocą.

Wedle [reguły] zakonu św. Bernarda ${ }^{91}$

zostały one zakonnicami,

${ }^{55}$ zgodnie z nauką ojca świętego

utrzymywały cześć zakonu,

od czego też nie odchodziły

we wszystkich swoich zamysłach,

kierując się zawsze

${ }^{60} \mathrm{ku}$ nieustannej służbie Bogu.

Gdy klasztor w tym czasie

był przygotowany, jak się podaje,

w następnym roku ${ }^{92}$

jak się to mówi jako prawdę -

${ }^{65}$ mistrz Dusemer w jego czasach,

jak Pan Bóg [to] doradził,

[ów] brat Heinrich Dusemer,

mistrz, i dostojnicy,

z bożej łaski

${ }^{70} \mathrm{i}$ za wspólną radą

ufundowali klasztor w Welawie ${ }^{93}$

Bogu na chwałę i widok,

zakonu braci mniejszych ${ }^{94}$,

Bogu i Jego umiłowanej matce

Quo perfecto in edificiis etc., in quo virgines Deo famulantur die ac nocte

secundum regulam sancti Benedicti.

idem magister

cum suis preceptoribus anno sequenti

statuit claustrum in Welow

ad Dei laudem,

in quo fratres minores

Deo devote horis statutis famulantur.

${ }^{\text {ooo }} B$ : Zcu.

ppp $B$ : vnde.

90 W znaczeniu: stużbę boża.

${ }^{91}$ Chodzi tu o regułę zakonu cystersów. Klasztor ów początkowo funkcjonowat jednakże wedle reguly benedyktyńskiej; zob. W. Franz, Das Benedikterinnenkloster St. Marien zu Königsberg, ,Altpreußische Forschungen”, 11, 1934, s. 170-171.

92 Wedle chronologii narracji bytby to 1349 r. W tym przypadku odpowiada to rzeczywistości, klasztor $w$ Welawie zostat bowiem ufundowany, podobnie jak lipnicki, w tym samym roku.

93 Welawa (niem. Wehlau, ob. ros. Знаменск/Znamensk), zamek i miasto zakonu niemieckiego położone w Prusach Dolnych, ok. 47,5 km na wschód od wspótczesnego Kaliningradu.

${ }^{4}$ Tj. franciszkanów. 


\section{Fragment VIII}

Podstawa rękopiśmienna: rekonstruowany rkps A: Karlsruhe, Badische Landesbibliothek, Cod. Donaueschingen A III 9, Fragm. B, k. 1r-2v; rekonstruowany rkps B: Karlsruhe, Badische Landesbibliothek, Cod. Donaueschingen A III 10, k. 2r (tylko początki wersów), 2v (tylko końcówki wybranych wersów).

Treść: fragment zawiera narrację dotyczącą wyprawy wojsk księcia Kiejstuta i wielkiego księcia Olgierda na Prusy Dolne w lutym $1352 \mathrm{r}$.

\section{Oryginal}

/A: $k .1 r / / / S R P I V$, s. $5 / /$

Ouch inderselbin wart

Der littowen her hart

Quamen dar by abendes czit

An dy gylge als man gyt

${ }^{5}$ Vnd jageten mit gewalt

Obir daz kvrische hab balt

Vnd hỳn czu den landen

De sy do irkanden

//SRP IV, s. 6// Vngewarnt worn

${ }^{10}$ Aldo ir byiorn

Vf dy vastnacht geschach

Daz ir her an vumf brach

Canusken das vlis vf ranten

Dy ersten czu schaden wanten

${ }^{15}$ By schoken se quomen

Dy heiden do vornomen

Schoker lant vorherten

Si ouch nicht das werten

Do is allis was gethan

${ }^{20}$ Wip kynt vnd man

Ouch vingen mit vngevugen

Ane dy se irslugen

Der was do besundert

Wol vf seben hundert

Tłumaczenie

I podczas tej samej warty ${ }^{95}$

wojsko Litwinów twardo

przybyło o wieczornej porze

nad Gilgę $e^{96}$, jak się podaje,

${ }^{5} \mathrm{i}$ szybko pociągnęło z mocą

przez Zalew Kuroński ${ }^{97}$,

i tutaj do ziem [pruskich].

Gdy tam rozpoznali,

[że ziemie] są nieostrzeżone ${ }^{98}$

${ }^{10}$ tamże na początku roku,

w Zapusty ${ }^{99}$ [to] się zdarzyło -

że ich wojsko podzieliło się na pięć [części].

Nad rzekę Canusken ${ }^{100}$ nadciągnęli

pierwsi, [by] czynić szkody.

${ }^{15}$ Przybyli pod Szaki ${ }^{101}$,

poganie poczęli

ziemię szacką ${ }^{102}$ pustoszyć,

i nie oszczędzili -

tam to wszystko zostało uczynione -

${ }^{20}$ kobiet, dzieci i mężczyzn.

Pochwycili też gwałtownie [ludzi] -

nie [licząc] tych, których zabili -

których było konkretnie

dobrze około 700 .
Laciński tekst tlumaczenia Konrada Gesselena

I//s. 254//I

[...] et nocte

cum grandi multitudine iuxta

Gilgam

et potenter festinant

trans stagnum vulgariter Kurische Hab, intrant terram,

incolis non avisatis,

in Carnisprivio

iuxta ///s. 256/// flumen vulgariter

Canusken, in 5 se partientes,

primi vertunt

se in terram Schcken,

quam depredantur

et vastant, occidunt,

capiunt mulieres etc.,

700 deducentes captivos.

${ }^{95}$ Mowa tu o grupach zbrojnych wysyłanych przez dostojników zakonu niemieckiego (jak również władców duchownych, tj. biskupów i kapituly) na wschodnie, pótnocno-wschodnie i południowo-wschodnie obrzeża kraju pruskiego na skraju obszarów puszczańskich, których celem było sprawowanie straży (wart) w lokalnych węzłowych punktach komunikacyjnych i na ich przedpolach. Niniejszy fragment kroniki mógłby wskazywać na dokonywanie mniej lub regularnych zmian owych wart.

${ }^{6}$ Gilga (niem. Gilge, ob. lit. Gilija, ob. ros. Матросовка/Matrosovka), rzeka będąca poludniowym ramieniem ujściowym Niemna.

97 Zalew Kuroński (niem. Kurisches Haff, ob. lit. Kuršiu marios, ob. ros. Kypmский залив/Kuršskij zaliv), zatoka na południowowschodnim wybrzeżu Morza Bałtyckiego oddzielona od otwartego akwenu Mierzeja Kurońska.

98 W znaczeniu: mieszkańcy tych ziem nie zostali ostrzė̇eni przez wysłane do puszczy warty/straże o zbliżającym się najeździe przeciwnika.

99 Tj. 21 II 1352.

${ }^{100}$ Rzeka ta nie daje się jednoznacznie zlokalizować, byt to zapewne jeden z cieków wptywajacy do potudniowo-wschodniej części Zalewu Kurońskiego.

101 Szaki (niem. Schaaken, ob. ros. Hекрасово/Nekrasovo), zamek zakonu niemieckiego położony na Sambii, ok. 24 km na pótnocny wschód od wspótczesnego Kaliningradu.

102 Obszar położony w pótnocno-wschodniej części Sambii, w okolicach Szaków. 


\section{Oryginal}

${ }^{25}$ De andir partye vf iageten

Das vlis sokuskem und lageten

Wy sy di cristen vellen Kvnden mit eren gesellen Von danne(n) dy heyden [si]ch wante(n)

${ }^{30}$ Indas lant Powunde(n) ranten

Do vingen mit vuge $[\mathrm{n}]^{\text {qqq }}$

Czu tode vil irsluge(n)

Gevangen heym santen

Was se gut irkanten

${ }^{35}$ Dÿ dritte partye d(er) konig hys

$/ A: k .1 v /$ Uf iagen cacte das vlis

Do sprengten se czu kaŷmen yn

Mit eÿme mechtigen here schÿn

Das lant von yn gar wart vorbrant

${ }^{40}$ Do nomen sy czu hant

Dy gevange(n) mit vngefugen

Ouch sy er vil irslugen

Dy man do rechent inder czal

Vumfhundirt was ir obir al

${ }^{45}$ De se czu lande sanden

/B: k. 2r--/ //SRP II, s. 518,

Fragm. VI--// Gar inharten banden

Dy virde heyden schar

Rante vf di deyme dar

Dar herten und branten

${ }^{50}$ Hyn und her dory(n)ne ranten

Do vingen se wip vnd man

Dy ${ }^{\mathrm{rT}}$ se vurten von dan

Der czal ${ }^{\text {sss }}$ was besundert

//SRP IV, s. 7// $\mathrm{Me}^{\text {ttt }}$ den virhundert

${ }^{55}$ Das vumfte teil hilt en abe
Tłumaczenie

${ }^{25}$ Druga partia [wojska] pociągnęła nad rzekę Sokuskem ${ }^{103}$; i [tam] się rozłożyli,

gdzie chrześcijan zgubić

mogli wraz z ich towarzyszami ${ }^{104}$.

Stamtąd poganie odeszli [i]

${ }^{30}$ wpadli do ziemi Powunden ${ }^{105}$,

gdzie z gwałtownością chwytali

i siekli na śmierć,

jeńców odesłali do swojego kraju,

co uznali za właściwe.

${ }^{35}$ Trzeciej partii [wojska] król ${ }^{106}$ nakazał $3^{\mathrm{a}}$ pars, jussu regis

pociągnąć nad rzekę Cacte $^{107}$.

Tam wpadli do [ziemi] Kaymen ${ }^{108}$

z potężnym wojskiem wspaniale ${ }^{109}$,

ziemia została przez nich całkiem spalona, quam comburunt etc. ut supra

${ }^{40} \mathrm{i}$ wzięli tam od razu

z gwałtownością jeńców,

a wielu też zabili,

których policzono

łącznie 500;

${ }^{45}$ tych wysłali do [swojego] kraju

i to w ciężkich kajdanach.

Czwarty pogański zastęp

wpadł nad Dejmę ${ }^{110}$,

gdzie pustoszyli i palili,

${ }^{50}$ wpadając tu i tam;

schwytali tam kobiety i mężczyzn,

których stamtąd uprowadzili,

[i] których konkretna liczba

większa [była] aniżeli 400 .

${ }^{55}$ Piąta częśćc ${ }^{111}$ skierowała się poniżej quinta pars
Laciński tekst tlumaczenia Konrada Gesselena

Alia pars convertit se

ad flumen Sokusken

et conatur christianos invadere

et convertunt

se in terram Powunden,

ubi eciam similia egerunt ut supra.

transeunt flumen Tacte

et intrant terram Kaymen

occidunt

et 500 captivos

mittentes ad patriam;

$4^{\text {ta }}$ cohors

transiit super flumen Deyme,

ubi similia agunt ut primi,

ubi de captivis ultra 400 educunt virorum et mulierum:

qq $H$ stusznie sugerowat pomyłke kopisty i lekcje 'ungevugen'; zob. Wigand (H:ZF), s. 6, przyp. a.

rrr $B$ : De.

sss $B: \mathrm{zc}[\mathrm{al}]$

ttt $B:$ Mer.

${ }_{103}$ Rzeka niezlokalizowana, zapewne również na Półwyspie Sambijskim.

104 W znaczeniu: ich stugami, pachotkami, famulusami.

${ }^{105}$ Obszar rozciagajacy się na Sambii w okolicach Powunden (ob. ros. Xpaбpoвo/Hrabrovo), zamku biskupów sambijskich położonego ok. $20 \mathrm{~km}$ na pótnoc od współczesnego Kaliningradu.

106 Prawdopodobnie chodzi tu o Kiejstuta (zob. przyp. 69).

107 Rzeka niezlokalizowana, zapewne również na Półwyspie Sambijskim.

108 Kaymen, obszar położony we wschodniej części Sambii, w okolicach Kaymen (niem. Kaymen/Kaimen, ob. ros. 3apeubel Zareč'e), ok. 25 km na pótnocny wschód od wspótczesnego Kaliningradu.

$109 W$ znaczeniu: działania tego oddziału mogły wzbudzać podziw (zob. Wigand (H:ZF), s. 6, przyp. 3). Albo Wigand von Marburg zastosowat tu podyktowany stylistycznie zabieg retoryczny estetyzacji świata przedstawionego w narracji, co by wskazywato, że estetyka militarna była dla niego wartościa, albo że korzystał z jakiejś niezachowanej starszej narracji (zob. przyp. 123), w której zawarta była tego rodzaju estetyczna waloryzacja. Taka spisana narracje przywołuje zreszta sam kronikarz (zob. w tym fragmencie w. 94).

${ }_{110}$ Dejma (niem. Deime, ob. ros. Дeŭмa/Dejma), rzeka będąca jednym z ramion Pregoty, uchodzaca do Zalewu Kurońskiego.

111 W znaczeniu: piąta część wojska. 


\section{Oryginal}

Do czu ${ }^{\text {uuu }}$ dem kuryschen habe

Dy hatten grosen such

Wy se ${ }^{\mathrm{vvv}}$ obir eyn bruch

Mochten noch erem vromen

${ }^{60}$ Ane schaden hyn komen

Inder czit czu vorn

Was is nicht bevroren $/--B$ :

k. $2 r / / /--S R P I I$, s. 518, Fragm. VI//

Ouch was is weich vnd nas

Dy heiden do wurden las

${ }^{65}$ Das bruch nichte(n) vorten

Kvnden weder korten

Hyn czu eren landen

Mit pẏnlichem anden

Dornoch der konig vo(n) smalencz

${ }^{70}$ Quam iagen als eyn wilder gencz

/A: $k$. $2 r$ / Hyn nahen vor labio

Dy cristen worn vnvro

/B: k. $2 v--/$ Der konig vru mit dem tage

Darczu insneller iage
Tlumaczenie

ku Zalewowi Kurońskiemu.

Ci usilnie poszukiwali, jakby $\operatorname{tam}^{112}$ przez pewne trzęsawisko ${ }^{113}$ mogli się z korzyścią

${ }^{60} \mathrm{i}$ bez szkód przeprawić,

które do tego czasu

nie było zamarznięte,

lecz miękkie i mokre.

Poganie się tam strwożyli,

${ }^{65}$ bowiem ani przebyć trzęsawiska ani [też] zawrócić nie mogli

do swoich krajów,

z przykrym i bolącym odczuciem.

Następnie król ze Smoleńska ${ }^{114}$

${ }^{70}$ przybył, nadciągając niczym dzika gęś ${ }^{115}$ tu w pobliże Labiawy ${ }^{116}$.

Chrześcijanie byli zmartwieni,

[a] król ${ }^{117}$ wcześnie o poranku w szybkim pochodzie

\section{Laciński tekst tlumaczenia} Konrada Gesselena

iuxtam stagnum, seu vulgariter Kurisch Habe, sollici querens,

quomodo per paludem grandem

absque dampno

transierent.

Tempus quoque tunc erat

fluidum sine gelu

nec poterant pertransire, et sic revertuntur

cum fatiga.

///s. 258/// \{108\} Post hec rex de Smaletz

festinat

prope Labio,

mane

иии $B$ : zcu.

vvv $B$ : do.

112 Stowo dodane na podstawie rkps. B.

113 Polożenia tego obszaru bagiennego nie da się określić.

114 Wedle literatury przedmiotu w 1352 r. władca Smoleńska byt Iwan Aleksandrowicz (zm. 1359) pochodzacy z rodu Rurykowiczów; zob. P.V. Golubovskij, Istoriâ Smolenskoj zemli do načala XV st., Kiev" 1895, s. 179-180; L. Vojtovič, Knâzìvs 'kì dinastï Shìnoï Êvropi (kinec' IX-počatok XVI st.): sklad, syspil'na i politična rol', L'vìv 2000, s. 242; P.V. Golubovskij, Knâža doba na Rysi: portreti eliti, Bila Cerkva 2006, s. 528. Jednak w kontekście informacji w w. 109 i wbrew wcześniejszej opinii sformułowanej w 2017 r. (zob. Wigand (Z/K), s. 259, przyp. 772) należy przyjmować, że chodzi tu o niezidentyfikowanego bratanka Kiejstuta, na co zreszta wskazuje sam tekst kroniki (zob. w. 107-108). J. Tęgowski, Pierwsze pokolenia Giedyminowiczów, Poznań-Wrocław 1999, s. 52, 73, przypuszcza (idąc za kontynuacja kroniki Matthiasa von Neuenburg jego własnego autorstwa), że byt to nieznany z imienia syn Olgierda z jego pierwszego matżeństwa (prawdopodobnie z bliżej nieznana Anna; zob. tamże, s. 51), przy czym jego śmierć datuje btędnie (za wspomniana kontynuacja) na 1353 r., odnotowując przy tym (zob. tamże, s. 52, przyp. 172) prawidłowa datację podana przez J. Voigta (zob. tenże, Geschichte Preussens von den ältesten Zeiten bis zum Untergange der Herrschaft des Deutschen Ordens, t. 5: Die Zeit vom Hochmeister Ludolf König von Weizau 1342 bis zum Tode des Hochmeisters Konrad von Wallenrod 1393, Königsberg 1832, s. 93-95). Przyjmując wiarygodność przekazu Wiganda, należałoby uznać, że w bliżej nieznanym czasie przed 1352 r. doszło do zmiany na tronie smoleńskim i przejęcia go przez przedstawiciela Giedyminowiczów, jak zreszta przypuszczał m.in. H. Paszkiewicz, Jagiellonowie a Moskwa, t. 1: Litwa a Moskwa w XIII i XIV wieku, Warszawa 1933 (repr.: 2014), s. 386, przyp. 3. Idac dalej tym tokiem myślenia, trzeba byłoby z kolei uznać, że w zwiazku ze śmiercia owego „króla ze Smoleńska” nad Dejma w lutym 1352 r. doszło $w$ kolejnych miesiacach do ponownego obsadzenia tronu smoleńskiego, co można bytoby wiąać z wyprawa wielkiego księcia moskiewskiego Siemiona Iwanowicza Dumnego i jego sprzymierzeńców na Smoleńsk; zob. B.N. Florâ, Bor'ba moskovskih knâzej za smolenskie i černigovskie zemli vo vtoroj polovinie XIV v., w: Problemy istoričeskoj geografii Rossii, t. 1: Formirovanie gosudarstvennoj territorii Rossii, Moskva 1982, s. 60-62; F. Mouchard, La Maison de Smolensk. Une dynastie princière du Moyen Âge russe (1125-1404), Bibliothèque russe de l'Institut d'études slaves, t. 131, Paris 2015, s. 211-212. Symptomatyczne jest jednak, że przekazy latopisarskie, wzmiankując tę wyprawę, nic nie mówia o zmianach na stolcu kniaziowskim w Smoleńsku. Problem ten wymaga niewątpliwie pogłębionych badań.

115 W znaczeniu: niezwykle szybko.

116 Labiawa (niem. Labiau, ob. ros. Полесcк/Polessk), zamek zakonu niemieckiego położony na Sambii, ok. 42 km na pótnocny wschód od współczesnego Kaliningradu.

117 Najprawdopodobniej chodzi tu o wspomnianego w w. 69 „,króla ze Smoleńska”, a każdym razie na pewno nie o Kiejstuta (zob. w. 107-108). 


\begin{tabular}{|c|c|c|}
\hline Oryginal & Tłumaczenie & $\begin{array}{l}\text { Laciński tekst tlumaczenia } \\
\text { Konrada Gesselena }\end{array}$ \\
\hline${ }^{75}$ Quam dar gar vordy் slege & ${ }^{75}$ przybył aż przed samą przesiekę. & ante septa veniens. \\
\hline Der kvmpthur alle wege & Komtur, & \\
\hline Bruder henny(n)g schyndekop & brat Henning Schindekop ${ }^{118}$, & Frater vero Henningus Scyndekoff \\
\hline Den heyden eynen weder klop & poganom wszystkie drogi zamknął & ei \\
\hline $\begin{array}{l}\text { Hot vor stalt veste vnd hart } \\
{ }^{80} \text { Das der konig czu der vart }\end{array}$ & $\begin{array}{l}\text { i zastawił mocno i twardo, } \\
80 \text { tak że król w tym czasie }\end{array}$ & fortiter resistens verberibus etc., \\
\hline Ayndirt obir dy rycke & gdzieś przez więzy $^{119}[\text { się skierował }]^{120}$, & \\
\hline Das macht der slege stricke & [a] przesiekę uczyniono sidłami. & \\
\hline $\begin{array}{l}\text { Der kvmpthur was en allis by } \\
\text { Dem konige vor den slege(n) } \\
\text { vry /--B:k. } 2 v /\end{array}$ & $\begin{array}{l}\text { Komtur był przy tym wszystkim } \\
\text { przed przesieką wcześniej od króla }{ }^{121} \text {, }\end{array}$ & paganos a septis, vulgariter slege, repellens, \\
\hline${ }^{85}$ Aldo wolden dy heyden & ${ }^{85}$ więc poganie nie chcieli & et procedunt \\
\hline Ouch nicht lange irbeyden & też długo wyczekiwać & \\
\hline An dy deyme vf das vlis & nad rzeką Dejmą, & ad fluvium vulgariter Deyme, \\
\hline Also sich der konig stis & zaś król uderzył ${ }^{122}$ & \\
\hline Das er indy deyme vil & tak że wpadł do Dejmy & in quod rex cecidit \\
\hline${ }^{90} \mathrm{Vnd}$ lif ym vol der gil & ${ }^{90}$ i zachłysnął się wodą. & et fere fuisset submersus, \\
\hline Den konig do vor strencte & Ku rozgoryczeniu króla & \\
\hline Der heyden vil vor sencte & wielu pogan potonęło, & in quo tamen multi de suis sunt submersi \\
\hline Do er czal was & których liczba wyniosła & numero \\
\hline Vumfhu(n)dert als ich las & $500-$ jak czytałem ${ }^{123}$ & 500 \\
\hline${ }^{95}$ Aldo dy deyme & ${ }^{95}$ Tamże Dejma & qui fluxu aque \\
\hline Heyden vurte yn dem seyme & pociągnęła [swoim] nurtem ${ }^{124}$ pogan & ducti sunt \\
\hline $\begin{array}{l}\text { //SRP IV, s. } 8 / / \text { Ayn verre in das wilde hab } \\
\text { Von danne(n) vurte ze hyn ap }\end{array}$ & $\begin{array}{l}\text { aż do Dzikiego Zalewu }{ }^{125} \text {, } \\
\text { stamtąd [zaś] poniżej }^{126} \text {. }\end{array}$ & in stagnum, vulgariter Wilde Hab dictum. \\
\hline $\begin{array}{l}\text { Bruder heynrich do sach vor wor } \\
{ }^{100} \text { Der konig nam des wassers kor }\end{array}$ & $\begin{array}{l}\text { Brat Heinrich }{ }^{127} \text { widział naocznie, } \\
{ }^{100}[\text { że] król zachłysnął się wodą }\end{array}$ & Unde rex temptans vada hinc \\
\hline Vnd was ingroser not & i był w wielkim niebezpieczeństwie, & inde vix obisset; quod \\
\hline Do snel vor truncken tot & szybko tam utonąwszy ${ }^{128}$. & comperiens frater Hennigus extraxit regem \\
\hline Bruder hennyng vs der deym & Brat Henning ${ }^{129} \mathrm{z}$ Dejmy & de flumine Deim \\
\hline
\end{tabular}

${ }^{118}$ Henning Schindekop (zm. 17 II 1370), brat rycerz zakonu niemieckiego, poświadczony w Zakonie w 1344 r., piastujący urzędy: komtura ragneckiego (\{26 V 1350\}-\{1352\}), komtura batgijskiego (\{25 VII 1356\}-\{2 II 1360\}) oraz wielkiego marszatka i komtura królewieckiego (\{5 IV 1360\}-17 II 1370).

119 W znaczeniu: skierowat się na przesieke, aczkolwiek od wewnątrz.

120 Tylko z dodaniem czasownika opisujacego dziatanie ,króla” fragment ten staje się zrozumiały.

121 Chodzi tu o wspomnianego w w. 69 „,króla ze Smoleńska”.

122 W znaczeniu: zaatakowat, najpewniej prowadząc uderzenie. Th. Hirsch proponowat nieco inne tlumaczenie (że „król” ruszyt szybko); zob. Wigand (H:ZF), s. 7, przyp. 9.

${ }^{123}$ Nie wiadomo, o jaki przekaz pisany tu chodzi. Wyprawa zimowa ksiażąt litewskich na Prusy w 1352 r. znana jest poza niniejsza narracja jedynie z krótkiej wzmianki w kontynuacji kroniki Matthiasa von Neuenburg (zob. przyp. 114). Nawet już jednak powierzchowna analiza treści obu narracji wskazuje, że dzieło zmarłego między 1364 a 1370 r. mieszczanina strasburskiego nie było podstawa źródłowa dla Wiganda von Marburg. Ten ostatni musiał zatem korzystać z innej utrwalonej pisemnie narracji o owej wyprawie, bliskiej chronologicznej opisywanym wydarzeniom. Z kolei Matthiasowi von Neuenburg wypada przypisać sięgnięcie do relacji (ustnych bądź pisemnych), które za pośrednictwem braci zakonu niemieckiego stosunkowo niedtugo po analizowanych tu wydarzeniach dotarly do zachodnich krajów Rzeszy.

124 Zob. Wigand (H:ZF), s. 7, przyp. 11.

${ }^{125}$ Dziki Zalew (niem. Wilde Hab), zapewne poludniowa część Zalewu Kurońskiego, której nazwa zwiazana mogła być z częstymi okresami niespokojnej (nieżeglownej) wody, w tym szkwałów; zob. Wigand (H), s. 518, przyp. 469.

126 W znaczeniu: dalej w głąb Zalewu Kurońskiego.

127 Niewątpliwie brat zakonu niemieckiego, osoba niezidentyfikowana. Th. Hirsch przyjmowat tu pomyłkę kopisty, uznając, że chodzi o Henninga Schindekopa; zob. Wigand (H:ZF), s. 8, przyp. 1.

${ }^{128}$ W. 99-102 stanowia narracyjny powrót do sytuacji wspomnianej uprzednio $w$ w. 88-90.

${ }^{129}$ Mowa tu o Henningu Schindekopie (zob. przyp. 118). 


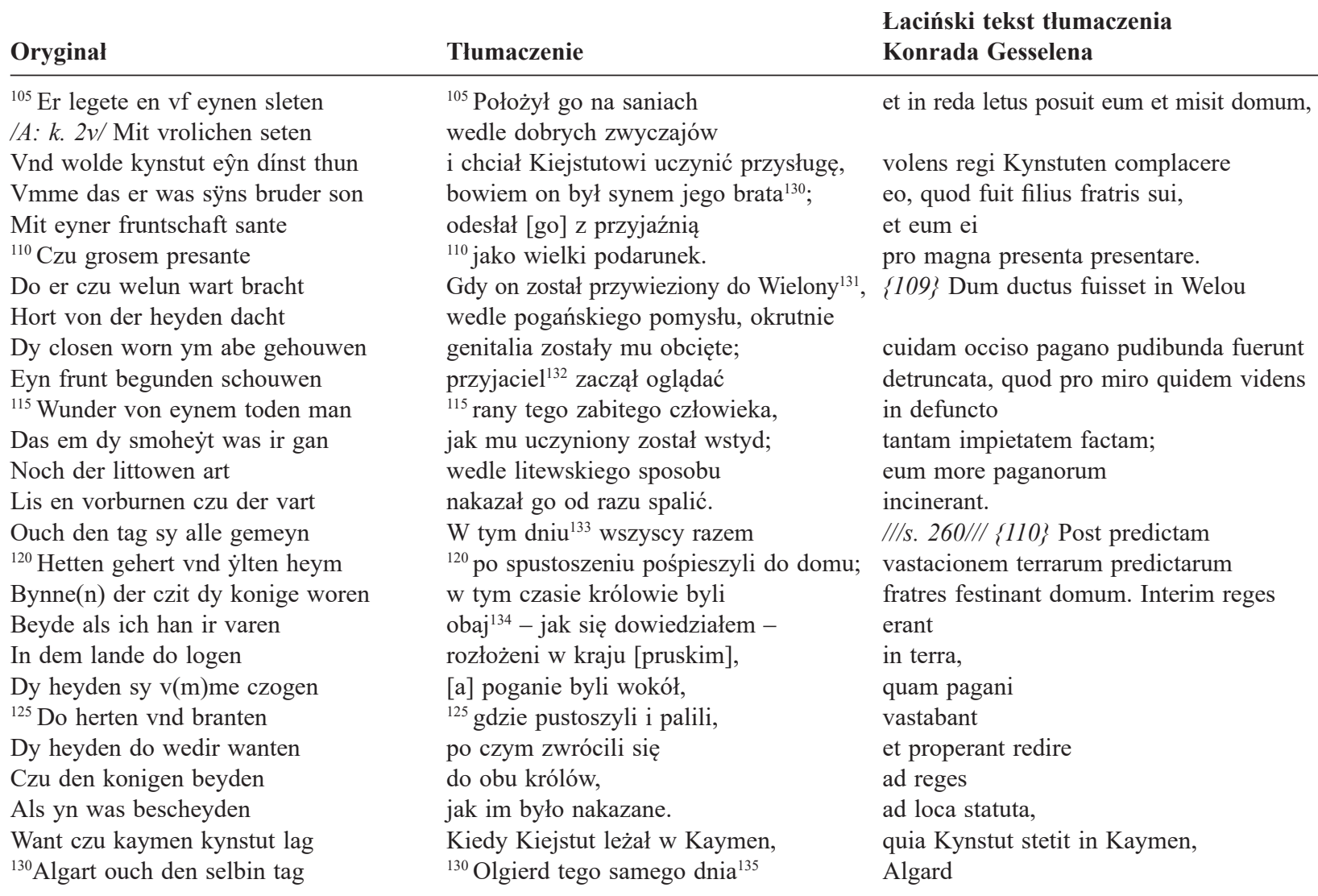

${ }^{130}$ Nie wiadomo, o którego spośród braci Kiejstuta może tu chodzić (J. Tęgowski wskazuje na Olgierda, zob. przyp. 114), ale musiatby to być któryś ze starszych braci, skoro jego syn w 1352 r. dowodził wojskiem na wyprawie. Przeciwko ojcostwu Olgierda przemawiałaby narracja Wiganda, w której mowa jest o odesłaniu zwłok „króla ze Smoleńska” na Litwę w celu uczynienia przyjaznego gestu Kiejstutowi (zob. w. 107-110), a nie Olgierdowi, który byt przecież obecny na tej wyprawie (czyżby strona zakonna o tym wówczas nie wiedziała?). Może więc chodziłoby tu o innego brata Kiejstuta, który nie brat udziału w przedsięwzięciu wojennym w Prusach Dolnych? Z drugiej jednak strony można też założyć, że komtur ragnecki Henning Schindekop chciat uczynić ,, wielki podarunek” - jak ów gest nazwat poetycko Wigand - Kiejstutowi, a nie Olgierdowi (mimo że odsytali wedle interpretacji J. Tęgowskiego zwłoki jego syna) z uwagi na fakt, że to z młodszym Giedyminowiczem mogły łączyć go wzajemne więzy utrwalonej już wówczas znajomości, ze względu na sprawowany od ponad póttora roku urząd komturski, a może i wcześniejszy pobyt w konwencie ragneckim oraz poświadczona $30 \mathrm{~V} 1344$ obecność w konwencie królewieckim (zob. Preußisches Urkundenbuch. Politische (allgemeine) Abteilung, t. 3, z. 2: 1342-1345, wyd. H. Koeppen, Marburg 1958, $n r$ 650, s. 534), na który to aspekt w kontekście relacji politycznych wskazywat w odniesieniu do innych postaci R. Petrauskas, Tolima bičiulystè: asmeniniai Vokiečiu ordino pareigūnu ir Lietuvos valdovu santykiai, w: Kryžiaus karu epocha Baltijos regionu tautu istorineje samonèje. Moksliniu straipsniu rinkinys, red. R.R. Trimoniene, R. Jurgaitis, Saulès 2007, s. 206-221. Kwestia pozostaje więc otwarta.

131 Wielona (lit. Veliuona), gród litewski położony nad dolnym Niemnem, ok. 33 km na wschód od Jurborkas (pol. Jurbork). Łacińskie tlumaczenie zawiera błędna identyfikację toponimu, wskazując w tym miejscu na dolnopruska Welawę (zob. przyp. 93).

${ }^{132}$ Zapewne w znaczeniu: przyjaciel księcia, jego bliski towarzysz. Liczba gramatyczna rzeczownika 'frunt' nie zgadza się tu ewidentnie z liczba gramatyczna czasownika 'beginnen', co należy chyba złożyć na karb pomytki kopisty i zastosować koniekture 'begund en' tj. 'begann ihn'.

${ }_{133}$ Data nieustalona.

134 Mowa tu o Kiejstucie i Olgierdzie.

${ }^{135}$ Data nieustalona. 


\begin{tabular}{|c|c|c|}
\hline Oryginal & Tlumaczenie & $\begin{array}{l}\text { Laciński tekst tlumaczenia } \\
\text { Konrada Gesselena }\end{array}$ \\
\hline Hilt indem lande Labiow & zatrzymał się w ziemi labiawskiej ${ }^{136}$. & in terra Labiow vulgariter dicta, \\
\hline Der heyden her quomen do & Wojska pogan tam nadeszły, & ubi conveniunt \\
\hline Czu samme(n) al hyn an & tamże wszyscy razem. & simul \\
\hline Der heyden konig von dan & Król pogan & \\
\hline${ }^{135}$ Indes erste(n)s slofens kenne(n) & ${ }^{135} \mathrm{~W}$ porze pierwszego spania ${ }^{137}$, & et in primo sompnio \\
\hline Jageten do balt von danne(n) & pociągnął szybko stamtąd & festinant a loco \\
\hline Hyn dan mit den gevangen & wraz z jeńcami, & cum captivis, \\
\hline Dy sy in grosem twangen & których oni $\mathrm{w}$ wielkim ucisku & \\
\hline $\begin{array}{l}\text { Vurten vnd roubes vil } \\
{ }^{140} \text { Des sy hatten ane czil }\end{array}$ & $\begin{array}{l}\text { prowadzili, oraz wiele łupów, } \\
{ }^{140} \text { których mieli bez liku. }\end{array}$ & rapina nimia, et transeunt sine dampno. \\
\hline
\end{tabular}

\section{Fragment IX}

Podstawa rękopiśmienna: nieznany rkps C (tekst znany z druku: C. Schütz, Historia rerum Prussicarum, Zerbst 1592, k. 86r; odmianki: C. Schütz, Historia rerum Prussicarum, [Leipzig] 1599, k. 76v).

Treść: fragment zawiera pierwszy zachowany urywek narracji dotyczącej wyprawy wojska krzyżowego pod wodzą wielkiego mistrza Winricha von Kniprode pod Kowno wiosną 1362 r.

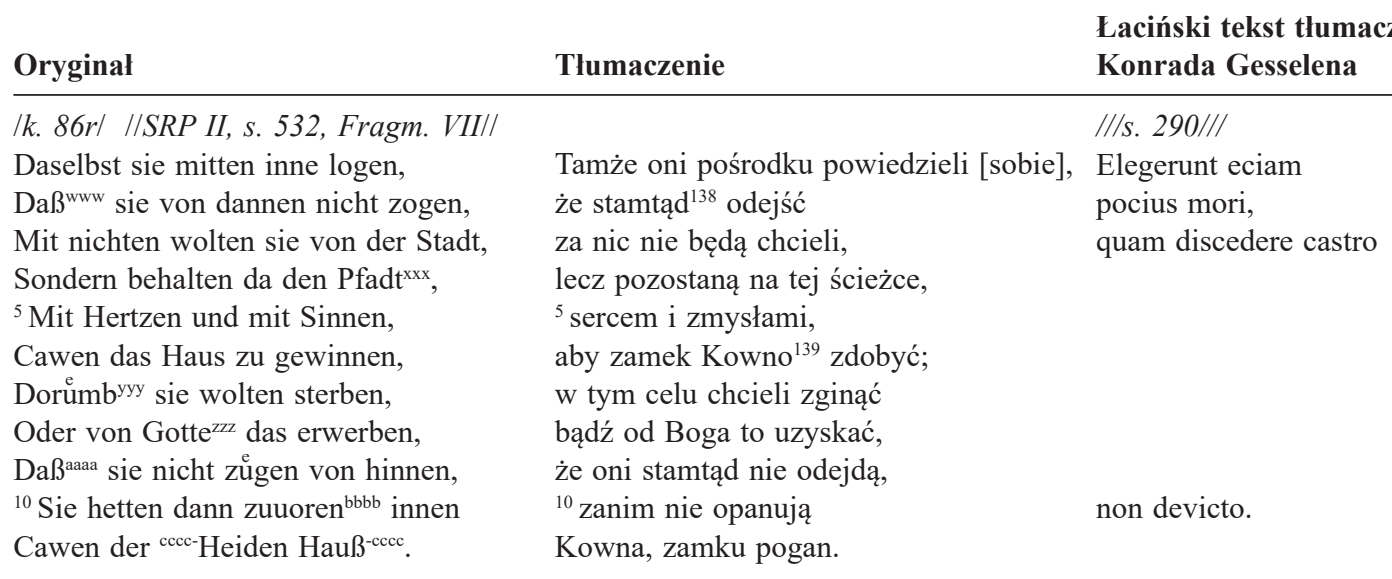

\footnotetext{
www Wydanie 1599: Das.

xxx Wydanie 1599: Pfad.

yyy Wydanie 1599: Dorumb.

zzz Wydanie 1599: Gott.

aaaa Wydanie 1599: Das.

bbbb Wydanie 1599: zuvor.

ccc-cccc Wydanie 1599: Heyden Haus.

136 Obszar położony wokót Labiawy (zob. przyp. 116).

137 Zapewne w znaczeniu: pierwszej straży.

138 Tj. spod Kowna (zob. przyp. 139).

139 Kowno (niem. Kauen, lit. Kaunas), zamek litewski nad dolnym Niemnem, położony przy ujściu doń rzeki Wilia (niem. Nerga, lit. Neris).
} 


\section{Fragment $X$}

Podstawa rękopiśmienna: nieznany rkps C (tekst znany z druku: C. Schütz, Historia rerum Prussicarum, Zerbst 1592, k. 86v-87v; odmianki: C. Schütz, Historia rerum Prussicarum, [Leipzig] 1599, k. 77r-78r).

Treść: fragment zawiera drugi, znacznie dłuższy aniżeli pierwszy, zachowany urywek narracji dotyczącej wyprawy wojska krzyżowego pod wodzą wielkiego mistrza Winricha von Kniprode pod Kowno wiosną 1362 r.

\section{Oryginal}

/k. 86v/ //SRP II, s. 534, Fragm. VIII//

Vnd an dem guten Freytage,

Da König Kinstute ${ }^{\text {dddd }}$ das sage,

Gar bald er dahin reiten kam,

Vnd hiesch den meister ${ }^{\text {reee }}$ aus bey nahm ${ }^{\text {ffffr }}$, i zawołał mistrza po imieniu,

/k. $87 r /{ }^{5}$ Auff daßgggg er zu hhh-jm keme-hhhh ${ }^{5}$ aby on do niego przybył;

Er wolte wort genehme,

Mit jme ${ }^{\mathrm{iiii}}$ reden vnd sprechen,

Sicherlich ohn allijij Gebrechen,

//SRP II, s. 535// Der Meister ${ }^{\text {kkkk-selber }}$ $\mathrm{kam}^{\text {-kkk }}$ dahin,

${ }^{10}$ Kinstoud sagte jm dießen ${ }^{1111}$ sinn, Meister were ich selbst auff $\mathrm{fmmm}^{\mathrm{mm}}$ dem Haußnnn,

Ir gewünt es nicht mit solchem grauß, Mit allen deinen Christenman,

Gewunest $^{0000}$ du mir doch nichts an,

${ }^{15}$ Der Meister wider gab Antwort ${ }^{\text {pppp }}$,

Weißlich vnd freysam also fort,

Was redestu nu von dem Hauß,

rrrr-Da du lengst sahest vnsern straus ${ }^{\mathrm{qqqq}}$, - rmr

Kinstoud der sprach wider also,

${ }^{20}$ Kein Heupt bey meinen Leuten do

Gewesen ist, in dieser zeit,

I w Wielki Piątek ${ }^{140}$

rzekł oto król Kiejstut ${ }^{141}$, porozmawiać przyrzeczenia

${ }^{15}$ Mistrz dał odpowiedź, »Co ty mówisz o zamku, Kiejstut rzekł znowu tak: nie była w tym czasie,

\section{Laciński tekst tlumaczenia} Konrada Gesselena

///s. 296/// niedługo po tym, jak on tam konno przybył vidisset,

[...] in feriam sextam parasceve. ///s. 298/// \{142\} Quod cum Kynstud vocavit magistrum, et sub mutuo salvo conductu sibi loquuntur, chciał z nim przyjemnymi słowy bezpiecznie bez jakiegokolwiek łamania Mistrz $^{142}$ sam [też] tam przybył ${ }^{143}$,

${ }^{10}$ Kiejstut rzekł mu w takim sensie: dixitque magistro: $»$ Mistrzu, gdybym był sam na zamku ${ }^{144}$, si ego essem in domo, nie zdobywalibyście go z taką okrutnością, nunquam eam obtineres ze wszystkimi twoimi chrześcijanami; cum omnibus tuis. niczego jednak nie zdobędziesz«. mądrze i spokojnie, mianowicie taką: choć widzisz od dawna naszą siłę«. ${ }^{20} »$ Żadna głowa ${ }^{145}$ przy moich ludziach
Cui magister respondit:

Quare equitasti de domo, cum nos videres, et respondit: quia mei non habebant caput;

\footnotetext{
dddd Wydanie 1599: Künstute.

eee $\quad W y$ danie 1599: Meister.

ffff Wydanie 1599: Nam.

gggg Wydanie 1599: das.

hhhh-hhhh Wydanie 1599: jhm kåme.

iiii Wydanie 1599: jhme.

ijij Wydanie 1599: al.

kkkk-kkkk Wydanie 1599: kam selbst.

1111 Wydanie 1599: diesem.

mmmm Wydanie 1599: aus.

nnnn Wydanie 1599: Haus.

oooo Wydanie 1599: Gewünnest.

ppp Wydanie 1599: antwort.

qqqq Wydanie 1599: Strauß.

rrr-rrтr UH brakuje tego wersetu.
}

${ }^{140} \mathrm{Tj} .15 \mathrm{IV} 1362$.

${ }^{141}$ Zob. przyp. 69.

${ }_{142}$ Mowa tu o Winrichu von Kniprode (zob. przyp. 40).

${ }_{143}$ Miejsce spotkania się Kiejstuta z Winrichem von Kniprode pod obleganym Kownem pozostaje niezlokalizowane.

${ }_{144}$ Mowa tu o obleganym przez wojsko zakonne zamku kowieńskim.

145 W znaczeniu: wódz. 


\section{Oryginal}

Darümb $^{\text {sss }}$ ich bey der Heiden ${ }^{\text {tttt }}$ Streit

Allewege ${ }^{\text {uuu }}$ selbsten muste ${ }^{\text {vvvv }}$ sein,

Vnd stehen mit meines selben schein,

${ }^{25}$ Da sprach der kủne Held der Meister,

Des Heerzuges ein guter Leister,

Ists sach daß ${ }^{\text {wwww }}$ dir Konig noth ist, So nim der Heiden ${ }^{\mathrm{xxx}} \mathrm{zu}$ dieser frist So viel du jryyyy wilt mit dir han,

${ }^{30}$ Die wollen wir alle semptlich lahn,

Vnd kom mit jnen zzzz auff das Hauß,

So erlaub ich dir ein vnd aus,

Hinan alle ewere ${ }^{\text {aaaa }}$ auffzo ge,

Vnd hilff du jn $n^{\text {bbbbb }}$ nach deim vermòge.

${ }^{35}$ Wir trawen Gotte ${ }^{\text {ccccc }}$ vnserm HErrn,

dddd-Daß jr ${ }^{\text {ddddd }}$ es nicht ko̊nnet erwehren ${ }^{\text {eeee }}$,

fffff-Vnd sollet es nicht behalten, ${ }^{-f f f f f}$

Fur unseren Gewalten.

Da sprach der König Kinstoud,

Dem gar vbel da ward zu Muth'gggg,

${ }^{40} \mathrm{Wie}$ mo $\mathrm{ehte}$ hhhhh ich auff das Hauß kommen,

Vnd schaffen daselbst meinen frommen, i uczynić tam to, co dla mnie dobre, Dieweil das Feld ist gar vergraben, kiedy pole jest całkiem rozkopane

Vnd ein grosser Zaun erhaben,

Als er war in den worten jach,

${ }^{45}$ Der Meister fortan also sprach,

Vnd bistu Ko̊nig so gewier,

Als ich das solte glauben dir,

//SRP II, s. 536// Vnd woltestu

nun einen Streit,

Mit vns machen in dieser zeit,
Tlumaczenie

stąd ja podczas pogańskiej walki wszędzie osobiście muszę być [obecny]

i stać z moim własnym obliczem«.

${ }^{25}$ Wtedy rzekł śmiały bohater - mistrz dobry wódz wyprawy:

»Jeżeli jest ci, królu, to konieczne,

to weź teraz pogan,

ile ich tylko chcesz ze sobą mieć,

${ }^{30}$ chcemy pozwolić [ci] ich wszystkich [zabrać],

i przyjdź z nimi na zamek,

zatem pozwalam ci wyjść i wejść

do środka we wszystkich waszych przyjazdach $^{146}$,

i pomóż im ${ }^{147}$ według twoich możliwości.

${ }^{35}$ My ufamy Bogu, naszemu Panu,

ze nie będziecie mogli się obronić

i nie powinniście się utrzymać

przed naszą mocąu.

Wtedy rzekł król Kiejstut, któremu było całkiem nieprzyjemnie:

${ }^{40} \gg$ Jak mógłbym na zamek przybyć i rozciąga się [tam] wielki płot ${ }^{148}$ ? « Jako że był w słowach szybki ${ }^{149}$,

${ }^{45}$ mistrz natychmiast tak rzekł: »Jeśli więc jesteś, królu, tak groźny, że ja powinienem tobie wierzyć, i chcesz teraz walkę

z nami stoczyć w tym czasie,

\section{Laciński tekst tłumaczenia} Konrada Gesselena

ideo mansi aput eos,

et ait magister:

si tibi opus fuerit, accipe de tuis, quotquot vis

et ascende liber domum.

Speramus enim in Domino, quod non poteritis eam protegere nec retinere.

Et Kynstud ait:

quomodo potero ascendere,

cum campus sit circumseptus et circumfossatus.

Cui magister:

promitte mihi,

quod velis

mecum bellare,

$\begin{array}{ll}\text { ssss } & \text { Wydanie 1599: Darumb. } \\ \text { tttt } & \text { Wydanie 1599: Heyden. } \\ \text { uuuu } & \text { Wydanie 1599: Allwege. } \\ \text { vvvv } & \text { Wydanie 1599: můste. } \\ \text { wwww } & \text { Wydanie 1599: das. } \\ \text { xxxx } & \text { Wydanie 1599: Heydn. } \\ \text { yyyy } & \text { Wydanie 1599: jhr. } \\ \text { zzzz } & \text { Wydanie 1599: jhnen. } \\ \text { aaaaa } & \text { Wydanie 1599: ewre. } \\ \text { bbbbb } & \text { Wydanie 1599: jhm. } \\ \text { ccccc } & \text { Wydanie 1599: Gott. } \\ \text { ddddd-ddddd } \text { Wydanie 1599: Das jhr. } \\ \text { ceee } & \text { Wydanie 1599: erwehrn. } \\ \text { fffff-fffrf } & \text { U H brakuje tego wersetu. } \\ \text { ggggg } & \text { Wydanie 1599: muth. } \\ \text { hhhhh } & \text { Wydanie 1599: mócht. }\end{array}$

146 W znaczeniu: podczas każdego wejścia/wjazdu księcia do obleganego zamku.

147 Tj. obrońcom zamku kowieńskiego.

148 Chodzi tu najprawdopodobniej o linię umocnień polowych wojska oblegajacego, które wzniesione zostaty zapewne w celu odcięcia obleganej warowni od zaplecza.

149 W znaczeniu: potrafit szybko reagować na wypowiedź interlokutora. 


\begin{tabular}{|c|c|c|}
\hline Oryginal & Tłumaczenie & $\begin{array}{l}\text { Laciński tekst tlumaczenia } \\
\text { Konrada Gesselena }\end{array}$ \\
\hline $\begin{array}{l}/ k .87 v /{ }^{50} \text { Wir wollen nieder iiiii legen, } \\
\text { Den Zaun zur Erden wegen, }\end{array}$ & $\begin{array}{l}{ }^{50} \text { [to] my chcemy zburzyć płot } \\
\text { równo z ziemią }\end{array}$ & volo planare terram \\
\hline $\begin{array}{l}\text { Vnd das Feld machen also schlecht, } \\
\text { Als es zuuoren }{ }^{\mathrm{ijjij}} \text { war gerecht, }\end{array}$ & $\begin{array}{l}\text { i pole uczynić tak równe, } \\
\text { jak ono było dobre przedtem«. }\end{array}$ & et septa deponere. \\
\hline $\begin{array}{l}\text { Der Kônig antwortete nicht, } \\
{ }^{55} \text { Dem Meister zu derselben schicht, }\end{array}$ & $\begin{array}{l}\text { Król nie odpowiedział } \\
{ }_{55}^{5} \text { mistrzowi na takie słowa. }\end{array}$ & Nec respondit ad hec rex, \\
\hline $\begin{array}{l}\text { Da sprach der Meister also fort, } \\
\text { Hette dann }{ }^{\text {kkkkk }} \text { der Kónig nicht mehr wort, } \\
\text { Mit vns zu reden diese zeit, } \\
\text { So warte er seiner Heiden }{ }^{11111} \text { streit. }\end{array}$ & $\begin{array}{l}\text { Wtedy rzekł ponownie mistrz tak: } \\
\text { »Jeśli zatem król nie ma więcej słów, } \\
\text { [aby] z nami teraz rozmawiać, } \\
\text { więc niech czeka na swoją pogańską } \\
\text { walke«. }\end{array}$ & $\begin{array}{l}\text { et magister: } \\
\text { si non habet rex amplius verba } \\
\text { nobiscum loqui, } \\
\text { transeat ad custodiam suorum. }\end{array}$ \\
\hline
\end{tabular}

\section{Fragment XI}

Podstawa rękopiśmienna: nieznany rkps C (tekst znany z druku: C. Schütz, Historia rerum Prussicarum, Zerbst 1592, k. 93r; odmianki: C. Schütz, Historia rerum Prussicarum, [Leipzig] 1599, k. 83r).

Treść: fragment zawiera laudację (bądź raczej jej znaczną część) na cześć zmarłego 24 VI 1382 wielkiego mistrza Winricha von Kniprode.

\begin{tabular}{|c|c|}
\hline Oryginal & Tłumaczenie \\
\hline \multicolumn{2}{|l|}{ /k. 93r/ //SRP II, s. 615, Fragm. IX// } \\
\hline Nach dem bey seiner Meisterschafft & Po tym podczas jego mistrzostwa ${ }^{150}$ \\
\hline Der Orden gut in grosser Krafft, & Zakon $^{151}$ dobrze w wielkiej sile \\
\hline Bestanden hat bey guter zeit, & trwał w dobrym czasie - \\
\hline Als man vns das für ware geit, & $\begin{array}{l}\text { jak to nam przedstawiono jako } \\
\text { prawdziwe. }\end{array}$ \\
\hline${ }^{5}$ Die Gebietiger mit grossen Wirden ${ }^{\mathrm{mmmmm}}$, & ${ }^{5}$ Dostojników z wielką godnością \\
\hline Hat er geehret auch mit Zierden ${ }^{\text {nnnnn }}$, & i chlubnie miał w poszanowaniu, \\
\hline Des Ordens Brüder in Geistligkeit, & braci Zakonu w kapłaństwie \\
\hline Hat er gehalten mit Weißheit. & traktował z mądrością, \\
\hline Ritter vnd Erbare Knechte, & rycerzy i czcigodnych knechtów ${ }^{152}$ \\
\hline${ }^{10}$ Gehalten in jrem ${ }^{\circ 0000}$ Rechte, & ${ }^{10}$ traktował wedle ich prawa, \\
\hline Gebawer vnd auch Bürger & chłopom oraz mieszczanom \\
\hline Fưr jm ${ }^{\text {ppppp }}$ gewest sein Achtber ${ }^{q q q q q}$, & okazywał swoje dostojeństwo, \\
\hline Vnd sonderlich den Bawerßman ${ }^{\text {rrmr }}$ & i w szczególności wieśniaków \\
\hline
\end{tabular}

\section{Laciński tekst tłumaczenia Konrada Gesselena}

///s. 480///

[...] annis magisterii generalis principatum in Pruszia tenuit, ex gracia divina speciale, in optimo statu;

preceptores quoque in maxima decencia tenuit

et ordinis fratres in sancta religione,

milites atque clientes

in justicia per suam prudenciam, cives et rusticos

\footnotetext{
iiiii Wydanie 1599: nider.

jijj Wydanie 1599: zuuorn.

kkkkk Wydanie 1599: denn.

1111 Wydanie 1599: Heyden.

mmmm Wydanie 1599: wirden.

nnnn Wydanie 1599: zierden.

oooo Wydanie 1599: jhrem.

ppppp Wydanie 1599: jhm.

qqqq Wydanie 1599: Achtbar.

rrrr Wydanie 1599: Bawersman.
}

${ }^{150}$ Mowa tu o urzędowaniu wielkiego mistrza Winricha von Kniprode (zob. przyp. 40).

151 Chodzi o zakon niemiecki.

152 Mowa tu o posiadaczach ziemskich bez pasa rycerskiego, tj. giermkach i zapewne również grupie tzw. wolnych (zob. przyp. 45). 


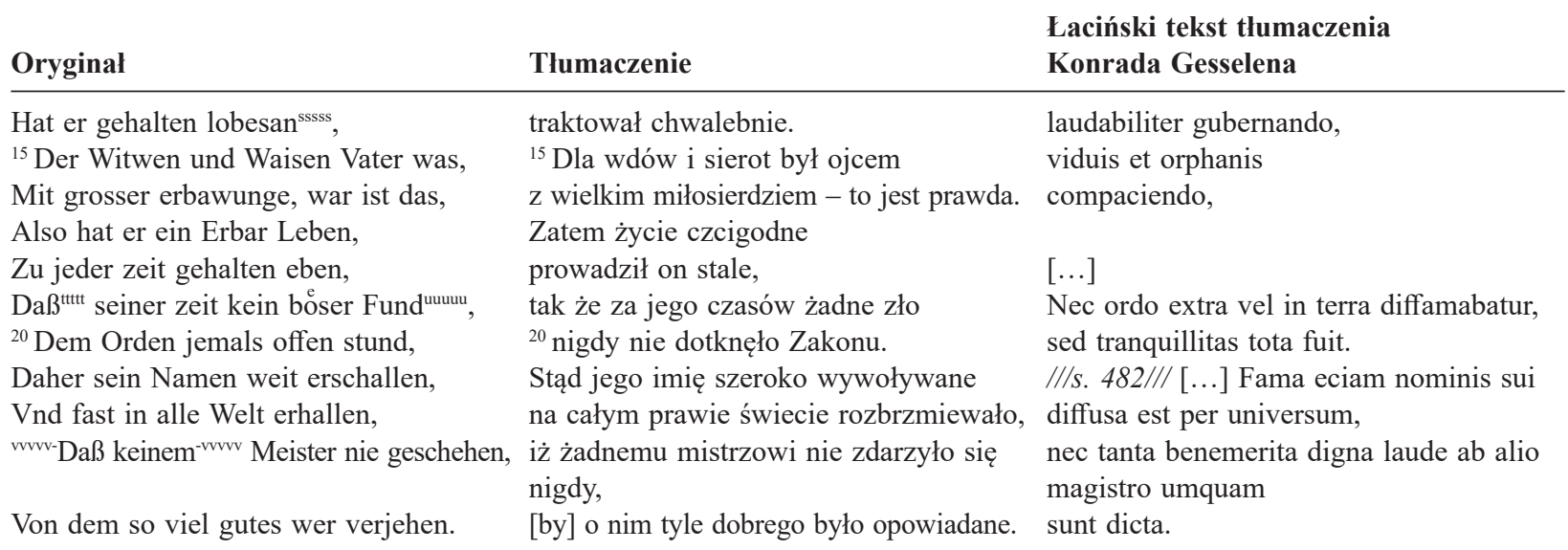

\section{Original fragments of the chronicle of Wigand von Marburg - Source study, new edition and Polish translation}

Summary: The article presents a new edition of the original fragments of Wigand von Marburg's chronicle that have been preserved. The edition complements the fifteenth-century Latin translation of the chronicle (with its Polish translation) published in 2017. The text contains eleven fragments of the original lines in verse composed in 1393-1394 in the East variant of the Middle High German. In total, they include 573 complete lines and 57 of their fragments that have survived. Five fragments are available today only in the sixteenth-century printed edition of Caspar Schütz's Historia rerum Prussicarum. At the same time, the remaining six have survived in the remains of late medieval manuscripts, currently kept in Vienna, Munich, and Karlsruhe. They come from two unpreserved codes (A and B), initially containing copies of probably the entire chronicle of Wigand von Marburg. A Polish translation of the original fragments in rhyme with their respective Latin translation are included in the edition.

Nota o autorze: Krzysztof Kwiatkowski, dr hab., prof. UMK, ur. 1982, absolwent Wydziału Nauk Historycznych Uniwersytetu Mikołaja Kopernika w Toruniu (2004), dr nauk humanistycznych w zakresie historii (2009), dr hab. nauk humanistycznych (2019). Od 2009 r. zatrudniony na Wydziale Nauk Historycznych UMK. Stypendysta m.in.: Fundacji na rzecz Nauki Polskiej, Deutscher Akademischer Austauschdienst, Stiftung Preußischer Kulturbesitz, Polskiej Misji Historycznej przy Uniwersytecie w Würzburgu. Kierownik i członek zespołów badawczych realizujących projekty naukowe w ramach grantów NCN i NPRH. Zainteresowania naukowe: historia militarna, historia społeczna, historia kulturowa, historia zakonu niemieckiego, historia Prus, edytorstwo źródeł historycznych.

Author: Krzysztof Kwiatkowski, professor of the Nicolaus Copernicus Univeristy, b. 1982, graduate of the Faculty of History, Nicolaus Copernicus University in Torun (2004), PhD in humanities in the field of history (2009), habilitation in humanities in the field of history (2019); since 2009, employee of the Faculty of History, Nicolaus Copernicus University in Toruń; scholarship holder i.a. of the Foundation for Polish Science, the German Academic Exchange Service, the Prussian Cultural Heritage Foundation, the Polish Historical Mission at the University of Julius Maximilian in Würzburg; head and member of research teams carrying out scholarly projects financed by the grants of the National Science Centre and the National Programme for the Development of the Humanities; his research interests include: military history, social history, cultural history, history of the Teutonic Order, history of Prussia, academic editing of historical sources.

\footnotetext{
sssss Wydanie 1599: Lobesan.

tttt $\quad$ Wydanie 1599: Das.

uuuu Wydanie 1599: fund.

vvvvv-vvvvv Wydanie 1599: Das.
} 
Katedra Historii Skandynawii i Europy Środkowo-Wschodniej

Instytut Historii i Archiwistyki

Wydział Nauk Historycznych

Uniwersytet Mikołaja Kopernika w Toruniu

ul. Bojarskiego 1

87-100 Toruń

e-mail: Krzysztof.Kwiatkowski@umk.pl

\section{Bibliografia}

\section{Źródla}

Barack K.A., Bruchstücke aus Wigand von Marburg Reimchronik, „Germania”, 12, 1867, s. 194-205

Brüchstück einer Reimchronik des Deutsch-Ordens aus dem Anfange des 15. Jahrhunderts, „Mittheilungen aus dem Gebiete der Geschichte Liv-, Ehst- und Kurland's", 3, 1845, s. 129-133

Die Chronik Wigands von Marburg. Originalfragmente, lateinische Uebersetzung und sonstige Ueberreste, wyd. Th. Hirsch, w: SRP, t. 2, Leipzig 1863, s. 453-662

Ein Fragment der Reimchronik Wigands von Marburg, wyd. W. Hubatsch, U. Arnold, w: SRP, t. 6, Frankfurt am Main 1968, s. 44-49

Hartknoch Ch., Alt- und Neues Preussen oder Preussischer Historien, Franckfurt-Leipzig 1684

Krömecke E., Ein Bruchstück eines mhd. Gedichtes, „Anzeiger für Kunde der deutschen Vorzeit”, N.F., 5, 1858, nr 10, szp. 335-336

Krömecke E., „Neue Preußische Provinzial-Blätter”, 3. Folge, 2, 1858, s. 357-358

Preußisches Urkundenbuch. Politische (allgemeine) Abteilung, t. 3, z. 2: 1342-1345, wyd. H. Koeppen, Marburg 1958

Schütz C., Historia rerum Prussicarum, Zerbst 1592

Schütz C., Historia rerum Prussicarum, [Leipzig] 1599

Thoma H., Ein neues Bruchstück aus der Reimchronik Wigands von Marburg, „Zeitschrift für deutsches Altertum und deutsche Literatur", 74, 1937, s. 39-45

Vygandas Marburgietis, Naujoji Prūsijos kronika, thum. R. Jasas, red. K. Gudmantas, Vilnius 1999

Wigand von Marburg, Cronica nova prutenica, oprac. S. Zonenberg, K. Kwiatkowski, Torun 2017

Zwei Fragmente der Reimchronik Wigands von Marburg, wyd. Th. Hirsch, w: SRP, t. 4, Leipzig 1870, s. 1-8

\section{Opracowania}

Barack K.A., Bruchstücke aus Wigand von Marburg Reimchronik, „Germania”, 12, 1867, s. 194-205

Blaschka A., Konrad Gesselen, ein Mitarbeiter von Johannes Dlugosz. Epilog zum „,Monumentum Thorunense”, „Wissenschaftliche Zeitschrift der Martin Luther Universität Halle-Wittenberg”, 10, 1961, nr 4, s. 893-895

Blaschka A., Monumentum Thorunense, „Wissenschaftliche Zeitschrift der Martin Luther Universität Halle-Wittenberg", 7, 1957/1958, nr 4, s. 715-726

Eichenberger N., Mackert Ch., Überarbeitung und Online-Publikation der Erschließungsergebnisse aus dem DFG-Projekt zur Neukatalogisierung der ehemals Donaueschinger Handschriften in der Badischen Landesbibliothek Karlsruhe, unter Mitarbeit von Ute Obhof sowie unter Einbeziehung von Vorarbeiten von Wolfgang Runschke und Sabine Lütkemeyer [Beschreibungen via Manuscripta Mediaevalia], <http://www.manuscriptamediaevalia.de/?xdbdtdn!\%22obj\%2031577285\%22\&dmode=doc\#|4> [dostęp: 22.03.2020]

Florâ B.N., Bor'ba moskovskih knâzej za smolenskie i černigovskie zemli vo vtoroj polovinie XIV v., w: Problemy istoričeskoj geografii Rossii, t. 1: Formirovanie gosudarstvennoj territorii Rossii, Moskva 1982, s. 58-80

Franz W., Das Benedikterinnenkloster St. Marien zu Königsberg, „Altpreußische Forschungen”, 11, 1934, s. 168-187

Golubovskij P.V., Istoriâ Smolenskoj zemli do načala XV st., Kiev" 1895

Golubovskij P.V., Knâža doba na Rysì: portreti eliti, Bìla Cerkva 2006

Handschriftenbeschreibung 2067, w: Handschriftencensus. Eine Bestandsaufnahme der handschriftlichen Überlieferung deutschsprachiger Texte des Mittelalters, <https://handschriftencensus.de/2067> [dostęp: 22.03.2020]

Handschriftenbeschreibung 2068, w: Handschriftencensus. Eine Bestandsaufnahme der handschriftlichen Überlieferung deutschsprachiger Texte des Mittelalters, <https://handschriftencensus.de/2068> [dostęp: 22.03.2020]

Hirsch Th., Einleitung, w: Die Chronik Wigands von Marburg. Originalfragmente, lateinische Uebersetzung und sonstige Ueberreste, wyd. Th. Hirsch, w: SRP, t. 2, Leipzig 1863, s. 429-452 
Jarzebowski M., Die Residenzen der preußischen Bischöfe bis 1525, Prussia Sacra, t. 3, Torun 2007

Jóźwiak S., Wyprawa armii krzyżackiej z Prus do Estonii w latach 1343-1344, „Komunikaty Mazursko-Warmińskie”, 238, 2002, nr 4, s. 495-500

Jóźwiak S., Trupinda J., Krzyżackie zamki komturskie w Prusach. Topografia i układ przestrzenny na podstawie średniowiecznych źródet pisanych, Toruń 2012

Kienhorst H., Lering en stichting op klein formaat. Middelnederlandse rijmteksten in eenkolomsboekjes van perkament, t. 2: Handschriften, Miscellanea Neerlandica, t. 32, Leuven 2005

Lackner F., współpr. A. Haidinger, Katalog der Streubestände in Wien und Niederösterreich, cz. 1: Nichtarchivalische mittelalterliche Handschriften und Fragmente in Korneuburg, Mistelbach, Retz, St. Pölten, Tulln, Waidhofen an der Thaya, Weitra, Wien, Wiener Neustadt und aus Privatbesitz. Katalogband und CD-ROM, Österreichische Akademie der Wissenschaften, Phil.-Hist. Klasse, Denkschriften, t. 272, Veröffentlichungen der Kommission für Schrift- und Buchwesen des Mittelalters, seria II, t. 5, Wien 2000

Malm M., Wigand von Marburg, w: Deutsches Literatur-Lexikon. Biographisches-bibliographisches Handbuch, t. 32, wyd. 3, Berlin-Boston 2013, szp. 341-343

Mouchard F., La Maison de Smolensk. Une dynastie princière du Moyen Âge russe (1125-1404), Bibliothèque russe de l'Institut d'études slaves, t. 131, Paris 2015

Paszkiewicz H., Jagiellonowie a Moskwa, t. 1: Litwa a Moskwa w XIII i XIV wieku, Warszawa 1933 (repr.: 2014)

Perlbach M., Der Übersetzer des Wigands von Marburg, „Altpreußische Monatsschrift”, 32, 1895, s. 411-424

Petrauskas R., Tolima bičiulystė: asmeniniai Vokiečiu ordino pareigūnu ir Lietuvos valdovu santykiai, w: Kryžiaus karu epocha Baltijos regionu tautu istorineje sąmoneje. Moksliniu straipsniu rinkinys, red. R.R. Trimonienè, R. Jurgaitis, Saulès 2007, s. 206-221

Schneider K., Die deutschen Handschriften der Bayerischen Staatsbibliothek München. Die mittelalterlichen Fragmente Cgm 5249-5250, Catalogus codicum manu scriptorum Bibliothecae Monacensis, t. 5, cz. 8, Wiesbaden 2005

Sumowski M., Duchowni diecezjalni w średniowiecznym Toruniu. Studium prozopograficzne, Torun 2012

Tęgowski J., Pierwsze pokolenia Giedyminowiczów, Poznań-Wrocław 1999

Thoma H., Ein neues Bruchstück aus der Reimchronik Wigands von Marburg, „Zeitschrift für deutsches Altertum und deutsche Literatur", 74, 1937, s. 39-45

Trimonienè R., Vygando Marburgiečio kronika. Ivadas, w: Vygandas Marburgietis, Naujoji Prūsijos kronika, tłum. R. Jasas, red. K. Gudmantas, Vilnius 1999, s. 5-45

Voigt J., Geschichte Preussens von den ältesten Zeiten bis zum Untergange der Herrschaft des Deutschen Ordens, t. 5: Die Zeit vom Hochmeister Ludolf König von Weizau 1342 bis zum Tode des Hochmeisters Konrad von Wallenrod 1393, Königsberg 1832

Vojtovič L., Knâzìvs'kì dinastï Shìdnoï Êvropi (kìnec' IX - počatok XVI st.): sklad, syspil'na i politična rol', L'vìv 2000

Vollmann-Profe G., Wigand von Marburg, w: Die deutsche Literatur des Mittelalters. Verfasserlexikon, t. 11: Nachträge und Korrekturen, red. B. Wachinger, G. Keil, K. Ruh, W. Schröder, F.J. Worstbrock, wyd. 2, Berlin-New York 2004, szp. 1658-1662

Wenta J., Studien über die Ordensgeschichtsschreibung am Beispiel Preußens, Subsidia Historiographica, t. 2, Toruń 2000

Witthöft H., Metrologische Überlegungen zur Kulmer Handfeste 1233/51, w: Beiträge zur geschichte des Deutschen Ordens, t. 2, wyd. U. Arnold, Quellen und Studien zur Geschichte des Deutschen Ordens, t. 49; Veröffentlichungen der Internationalen Historischen Kommission zur Erforschung des Deutschen Ordens, t. 5, Marburg 1993, s. 68-86

Wolff L., Wigand von Marburg, w: Die Deutsche Literatur des Mittelalters. Verfasserlexikon, t. 4, red. K. Langosch, Berlin 1953, szp. 964-968

Zajączkowski S., Polska a Zakon Krzyżacki w ostatnich latach Władysława Łokietka, Archiwum Towarzystwa Naukowego we Lwowie, Dział 2, t. 6, z. 2, Lwów 1929

Zonenberg S., Kronika Wiganda z Marburga, Bydgoszcz 1994

Zonenberg S., Wstęp źródloznawczy i historyczny, w: Wigand von Marburg, Cronica nova prutenica, oprac. S. Zonenberg, K. Kwiatkowski, Toruń 2017, s. 13-44

\section{Strony internetowe}

Mittelalterliche Handschriften in Österreich, <https://manuscripta.at/hs_detail.php?ID=1667> [dostęp: 22.03.2020] 